\title{
Economic Impacts of the Turfgrass and Lawncare Industry in the United States
}

\author{
John J. Haydu, PhD, Professor, University of Florida, Mid-Florida Research and Education Center \\ 2725 Binion Rd., Apopka, Florida 32703; email jjh@ifas.ufl.edu \\ Alan W. Hodges, PhD, Associate, University of Florida, Food \& Resource Economics Department \\ PO Box 110240, Gainesville, Florida 32611; email awhodges@ufl.edu \\ Charles R. Hall, PhD, Professor, University of Tennessee, Department of Agricultural Economics \\ 2621 Morgan Circle, Room 314B, Knoxville, Tennessee 37996; email crh@utk.edu
}

\section{EXECUTIVE SUMMARY}

The turfgrass and lawncare industry in the United States continues to grow rapidly due to strong demand for residential and commercial property development, rising affluence, and the environmental and aesthetic benefits of turfgrass in the urban landscape. Economic sectors of the industry include sod farms, lawncare services, lawn and garden retail stores, and lawn equipment manufacturing. Golf courses were included in this study as a major industry that depends upon highly managed turfgrass for golf play. Numerous studies have been conducted on the economic impacts of the turfgrass and lawncare industry for individual states or regions; however, this research is the first to report results for the entire United States.

Economic impacts of the U.S. turfgrass and lawncare industry in 2002 were estimated based upon survey data in conjunction with various published sources of secondary data, and economic multipliers derived from regional input-output models for each state using the Implan software system and associated datasets. Information gathered for each sector included number of establishments, employment, payroll, and sales receipts. Sources included the 2002 Census of Agriculture (sod farms), the 2002 Economic Census Industry Report Series, and County Business Patterns (U.S. Commerce Department).

As defined in this study, the five sectors comprising the U.S. turfgrass industry in 2002 generated total output (revenue) impacts of $\$ 57.9$ billion (Bn), employment impacts of 822,849 jobs, value added impacts of $\$ 35.1 \mathrm{Bn}$, labor income of $\$ 23.0 \mathrm{Bn}$, and $\$ 2.4 \mathrm{Bn}$ in indirect business taxes to local and state governments. If these values are expressed in 2005 dollars, the total output impact was $\$ 62.2 \mathrm{Bn}$ and the total value added impact was $\$ 37.7 \mathrm{Bn}$. The value added impact represents total personal and business net income.

Among individual sectors, sod producers created nearly \$1.8 Bn in output impacts, \$1.3 Bn in value added, and 17,028 jobs. Lawn equipment manufacturers contributed \$8.0 Bn in output, $\$ 2.5 \mathrm{Bn}$ in value added, and supported nearly 34,000 jobs. The lawncare goods retailing sector produced $\$ 9.1 \mathrm{Bn}$ in output impacts, contributed \$5.8 Bn in value added, and sustained 114,294 jobs. The lawncare services sector generated nearly $\$ 19.8 \mathrm{Bn}$ in output impacts, \$13.3 Bn in value added, and 295,841 jobs. Golf courses had \$23.3 Bn in output impacts, \$14.5 Bn in value added, and 361,690 jobs.

Economic impacts were summarized for individual states and seven geographic regions of the United States, with the turfgrass and lawncare industry having significant activity in all areas of the United States. The top ten individual states in terms of employment impacts were California $(101,022$ jobs), Florida $(83,944)$, Texas $(52,784)$, Ohio $(33,154)$, Illinois $(31,625)$, Pennsylvania $(30,845)$, North Carolina $(28,860)$, Georgia $(27,327)$, South Carolina $(25,083)$, and New York $(23,965)$. Regionally, the Southeast was the largest in terms of employment impacts $(197,711$ jobs), followed by the East-Central $(159,358)$, Western Coastal $(130,862)$, South-Central $(112,284)$, North-Central $(100,738)$, Western-Interior $(64,226)$, and Northeast $(57,671)$. 


\section{TABLE OF CONTENTS}

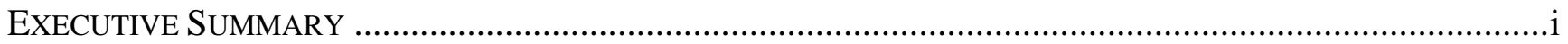

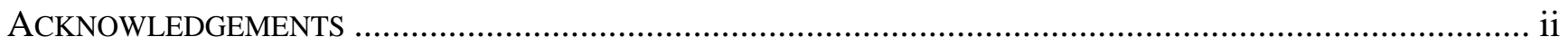

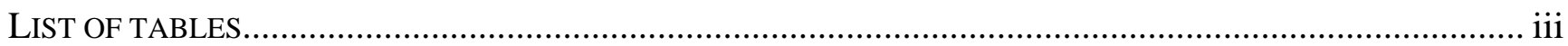

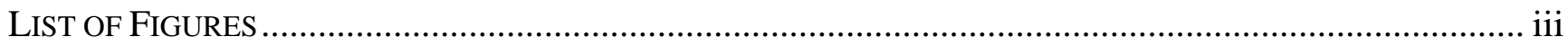

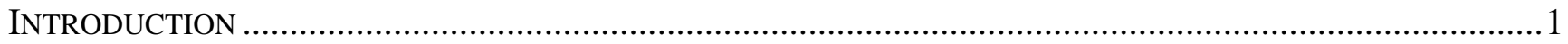

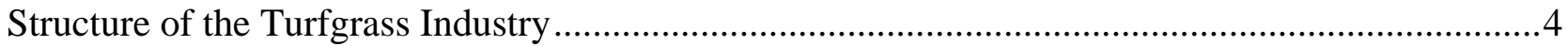

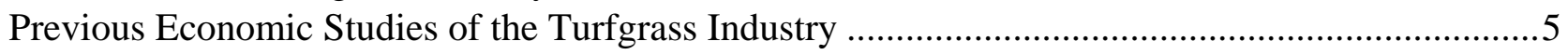

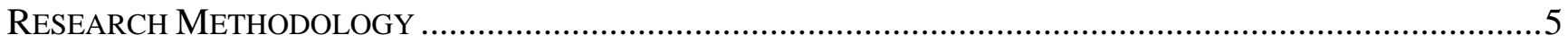

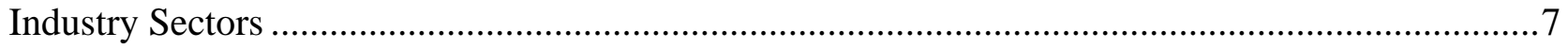

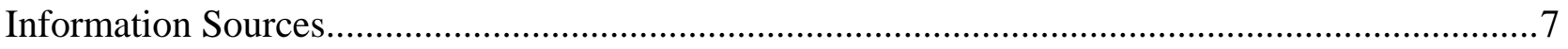

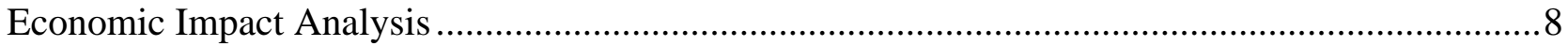

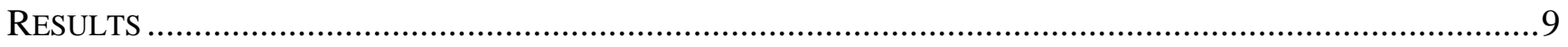

National Results for All Industry Sectors ...........................................................................

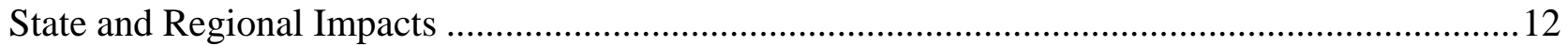

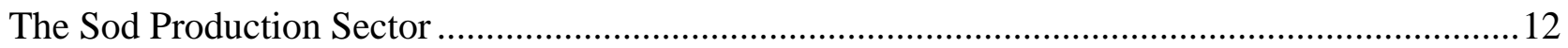

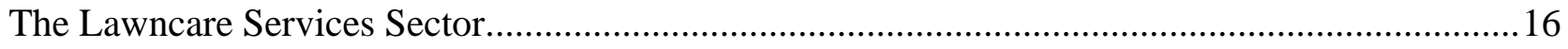

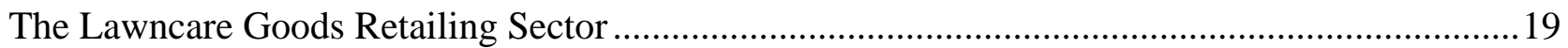

The Lawn Equipment Manufacturing Sector ..................................................................21

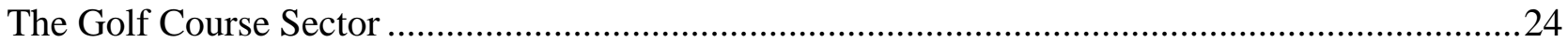

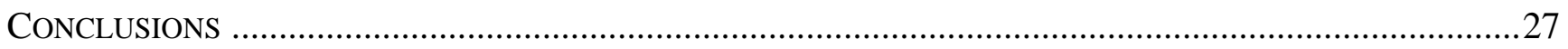

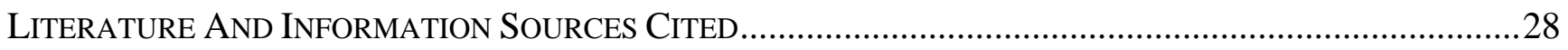

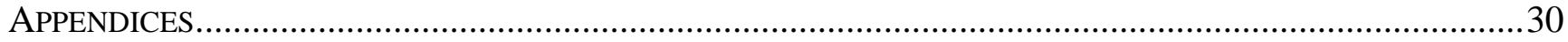

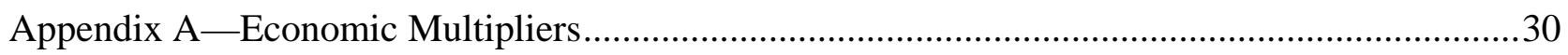

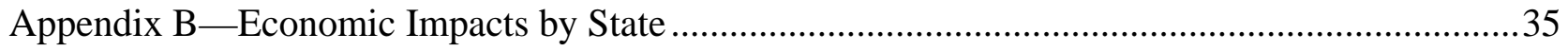

\section{Acknowledgements}

This study was sponsored in part by the International Turfgrass Research Foundation, Turfgrass Producers International, Rolling Meadows, IL

This is EDIS document FE632, a publication of the Food and Resource Economics Department, Florida Cooperative Extension Service, Institute of Food and Agricultural Sciences, University of Florida, Gainesville, FL. Published April 2006. Please visit the EDIS website at http://edis.ifas.ufl.edu. 


\section{LIST OF TABLES}

Table 1. Previous economic impact studies of the turfgrass industry, 1978-2004 .............................6

Table 2. Classification of sectors associated with the turfgrass and lawncare industry ......................... 7

Table 3. Summary of economic impacts of the turfgrass and lawncare industry in the United States,

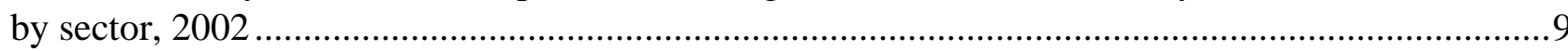

Table 4. Employment and value added impacts of the U.S. turfgrass and lawncare industry,

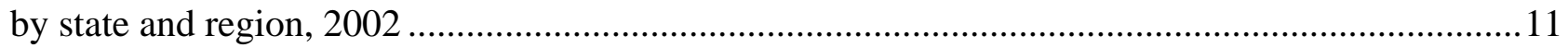

Table 5. U.S. sod farms, production and harvested area, 2002 ........................................................ 13

Table 6. Characteristics of U.S. sod production, by region......................................................... 14

Table 7. Value of U.S. turfgrass-related landscape services specialties.............................................17

Table 8. Value of U.S. lawn equipment manufacturing shipments, 2002 .......................................21

Table A-1. Multipliers for sod farms (nursery and greenhouse sector)..........................................30

Table A-2. Multipliers for lawncare services (services to buildings sector). ....................................31

Table A-3. Multipliers for lawncare retailing (building materials and garden supplies stores sector). 32

Table A-4. Multipliers for lawn and garden equipment manufacturing ...........................................33

Table A-5. Multipliers for golf courses (amusement, gambling and recreation services). ...................34

Table B-1. Economic impacts of U.S. sod production, by state, 2002 ...........................................35

Table B-2. Economic impacts of U.S. lawncare services, by state, 2002. ......................................36

Table B-3. Economic impacts of U.S. lawncare goods retailing, by state, 2002 .............................37

Table B-4. Economic impacts of U.S. lawn equipment manufacturing, by state, 2002.....................38

Table B-5. Economic impacts of U.S. golf courses, by state, 2002 ................................................39

\section{LIST OF FIGURES}

Figure 1. Market structure of the turfgrass industry............................................................ 4

Figure 2. Employment impacts of the U.S. turfgrass and lawncare industry, 2002 .........................10

Figure 3. Top ten states for output impacts of the sod production sector, 2002 ...............................15

Figure 4. Top ten states for employment impacts of the sod production sector, 2002 .........................15

Figure 5. Top ten states for value added impacts of the sod production sector, 2002 ........................16

Figure 6. Top ten states for output impacts in the lawncare services sector, 2002. ...........................18

Figure 7. Top ten states for total employment impacts in the lawncare services sector, 2002.............18

Figure 8. Top ten states for economic value added impacts in the lawncare services sector, 2002......19

Figure 9. Top ten states for output impacts of the lawncare goods retailing sector, 2002..................20

Figure 10. Top ten states for total employment impacts of the lawncare goods retailing sector, 2002. 20

Figure 11. Top ten states for value added impacts of the lawncare goods retailing sector, 2002 .........21

Figure 12. Top ten states for output impacts in the lawn equipment manufacturing sector, 2002........22

Figure 13. Top ten states for employment impacts of lawn equipment manufacturing sector, 2002 ....23

Figure 14. Top ten states for value added impacts of lawn equipment manufacturing sector, 2002 ....23

Figure 15. Top ten states for output impacts of the golf course sector, 2002 ..................................25

Figure 16. Top ten states for employment impacts of the golf course sector, 2002 ..........................25

Figure 17. Top ten states for value added impacts of the golf course sector, 2002............................26 


\section{INTRODUCTION}

Cultivated turfgrass is a pervasive feature of the urban landscape in the United States and many other developed regions of the world. According to Beard (1973), turfgrass provides at least three major benefits to human activities: functional, recreational, and ornamental. Functional uses include wind and water erosion control, thereby reducing dust and mud problems surrounding homes and businesses. Metropolitan areas and suburban residences profit from the cool, green pleasant environment afforded from healthy lawns, with landscapes frequently complemented by numerous trees, flowers and shrubs. Turf is also recognized for reducing glare, noise, air pollution and heat buildup. Turf is used extensively along roadsides for erosion control and as a stabilized zone for emergency stopping and repairs. Recreational use of turf is extensive throughout the world. Common sports activities played on turf include golf, lawn tennis, soccer, rugby, polo, and football. Most professional and recreational sports utilize grass surfaces because of its ability to minimize injuries (compared to hard surfaces) and provide a durable groundcover capable of cost-effective regeneration from season to season. Ornamental or aesthetic attributes of turfgrass are also highly regarded. Properly landscaped homes and businesses may also benefit financially from higher resale values when compared to poorly landscaped residences (Behe, et al, 2005; Des Rosiers, et al, 2002; Henry, 1999; Orland, et al, 1992).

\section{Structure of the Turfgrass Industry}

In the United States, a very large industry has rapidly evolved to produce and deliver turfgrass products and services. This industry contributes to the national economy in terms of employment, spending on inputs, income from sales of turfgrass products and services, as well as business taxes generated by its economic activities. Economic activity in the turfgrass industry may be broadly grouped into two categories: 1) production and supply of turfgrass products and related services and 2) intermediate and final consumption of turf products and services. The supply of turfgrass products includes not only grass but also the many goods necessary for production and maintenance, such as chemicals, fertilizer and lawn equipment. Turfgrass service activities include landscape planning and design, landscape installation and the ongoing maintenance of turfgrass areas. Consumption of turfgrass products and services may be subdivided as (a) integral turf-based activities, such as golf courses or athletic fields, which rely heavily on turfgrass as a major driver of their business and (b) ancillary uses, such as lawns surrounding homes, businesses, and public roads and highways.

The structure of the turfgrass industry and the flow of goods and services among the various sectors of the industry are shown in Figure 1. Central to this economic activity are the sod growers who create the product that is directly or indirectly utilized by the rest of the industry. Manufacturers of turf equipment, fertilizers and chemicals hold a similar economic role as primary producers. Wholesalers, retailers, and service vendors purchase and resell sod and other turfgrass products together with their related services to consumers. These market intermediaries provide value-added services to customers including transportation, packaging, installation, and product use information. In addition, lawn
Figure 1. Market structure of the turfgrass industry.

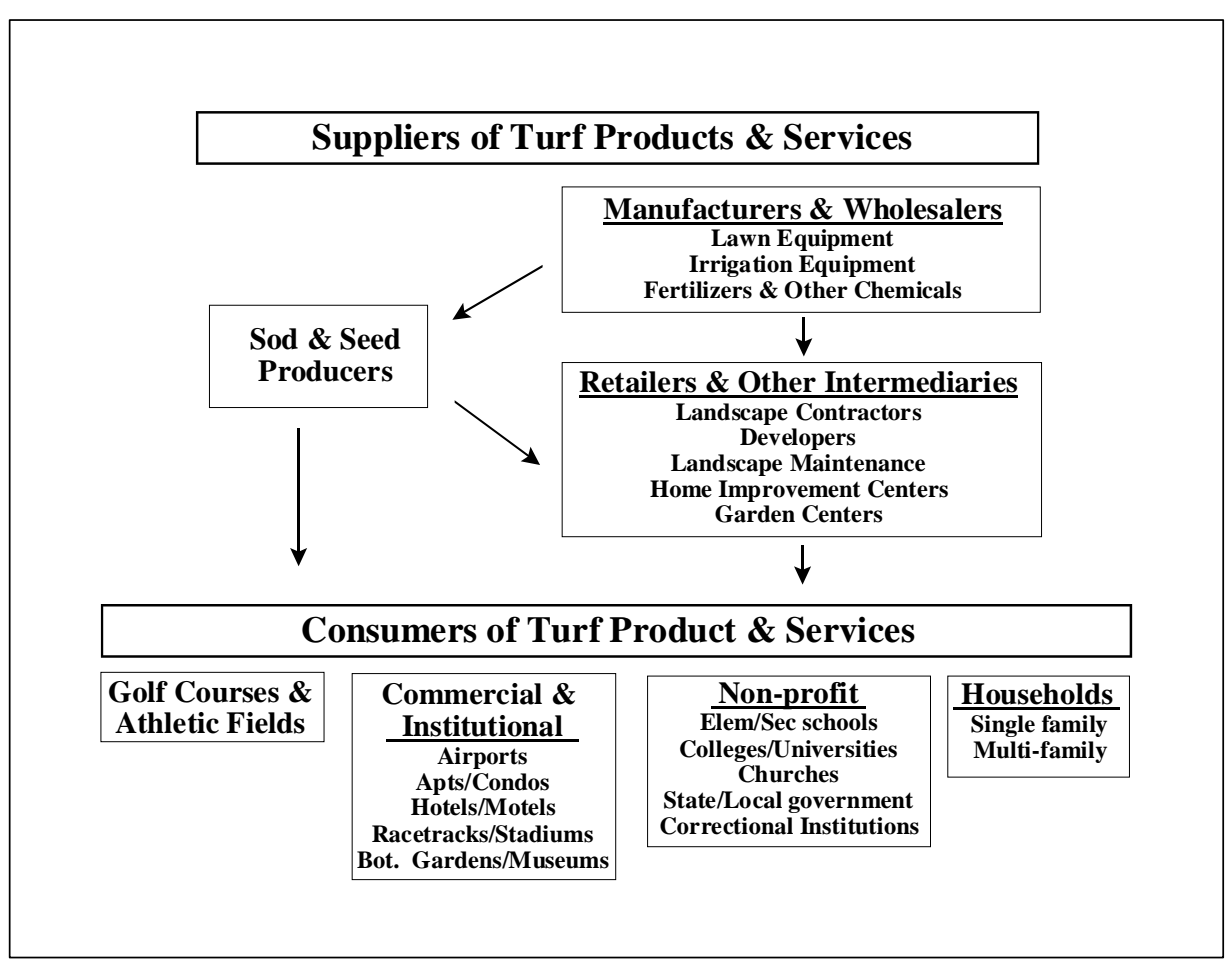


maintenance service vendors provide complete lawn care services, such as mowing, pest and disease control, irrigation and fertilization. Each of these service activities adds value to turfgrass products for final consumers.

The purpose of this study was to document the size, scope and structure of the turfgrass industry and to assess its economic contribution to the United States economy. Input-output (IO) models were employed to generate multipliers that account for the full range of economic activity between industry sectors within each state. I-O models capture what each business or sector must purchase from every other sector to produce its products and services. Variables examined in this analysis include output or total sales impacts, employment (jobs generated), value added (net income after direct costs are subtracted from gross output), labor income, and indirect business taxes. Total impacts include the direct effects, which are changes in economic activity resulting from the sale of a product or service to intermediate or final consumers; indirect effects of economic activity arising from purchases of inputs by the directly affected sectors; and induced effects from household spending as a result of income earned by industry employee. As an example of indirect impacts, sod sales by a producer results in purchases of inputs such as seeds, fertilizer, and chemicals as he replants his harvested fields.

\section{Previous Economic Studies of the Turfgrass Industry}

For many decades the U.S. Department of Agriculture has collected detailed production and financial data on the farm sector. This information has been used by government agencies, universities, and trade associations to track changes in the size and scope of the various agricultural industries over time. However, not all sectors of agriculture were included in the government's early data collection effort. Typically, those sectors incorporated were limited to large-scale "food \& fiber" commodities, such as corn, soybeans, cotton, citrus, dairy, and cattle. This decision to focus on the largest, most common sectors of agriculture was largely cost driven - it was simply too expensive for the government to collect detailed information on the many hundreds of relatively minor "specialty crops" that were produced in this country. In the past 20 years, the economic significance of specialty crops has grown appreciably and, as a consequence, the USDA now conducts broader studies that include nearly all specialty crops. Additional studies have been conducted that focus on ornamental crops and turfgrass, such as "Floriculture and Nursery Crops Outlook" (USDA/ERS, 2005). While these studies have filled a void in government statistics for "green industry" crops, due to the large numbers of specialty crops produced and the number of states producing them, information collected is for the most part limited to area under production (acres or square feet).

Since the early 1970s the economic importance of the green industry has grown substantially, making it the second most important sector in agriculture (USDA/NASS, 2004). This development was spurred primarily by rapid population growth and rising household incomes that began in the early 1990s and continues today. With an expanding economy, more disposable income, and extremely low interest rates, the demand for new home construction rose markedly as well. A strong upturn in the construction of homes, commercial businesses and schools translated into a similarly strong upturn in the demand for landscape materials, including turfgrass. This in turn prompted the green industry to ratchet up supply of products and services, hence the remarkable growth of this industry.

The downside to urban population growth and green industry expansion is the pressure it places on scarce resources, particularly land and water. Competition for these resources is felt in many parts of the country, but is particularly acute in densely populated areas (Carriker, 1993; Campbell \& Sargent, 2001; Haydu et al, 2004). As industries struggle for access to more water and land, the incentives to document their economic contributions to society have grown. As a result, a recent abundance of "green industry" studies funded largely by state trade associations and conducted by University economists and horticulturists have been published. The scope of industry publications and the methodologies employed vary widely, but all have a common theme and purpose of documenting the economic contribution of their respective industries. A list of over 50 of these state-level publications spanning the period 1978 to 2004 is presented in Table 1. The titles of these studies can be grouped into three categories: 1) studies that have general titles such as "Green Industry Survey", "Environmental Horticulture" or "Nursery Industry", most of which also cover the turfgrass industry as well; 2) studies with titles that identify both nursery and turfgrass explicitly; and 3) studies with turfgrass titles only.

The present study extends findings from a previous study by the same authors (Hall, Hodges and Haydu, 2005) which estimated economic impacts for the Green Industry in the United States, of which turfgrass-related activity is an important component. 
Table 1. Previous economic impact studies of the turfgrass industry in individual states, 1978-2004.

\begin{tabular}{|c|c|c|}
\hline $\begin{array}{c}\text { Year } \\
\text { Reported }\end{array}$ & State & Scope \\
\hline 2004 & Wisconsin & Green Industry Survey \\
\hline 2004 & New England & Environmental Horticulture \\
\hline 2003 & New Jersey & Turfgrass Industry \\
\hline 2003 & New York & Turfgrass Industry \\
\hline 2002 & Nevada & Green Industry Operations \\
\hline 2002 & Colorado & Green Industry \\
\hline 2002 & Michigan & Turfgrass Industry \\
\hline 2002 & Arizona & Green Industry \\
\hline 2002 & Georgia & Golf Course and Landscape Maintenance \\
\hline 2001 & Iowa & Turfgrass Industry \\
\hline 2001 & Idaho & Green Industry \\
\hline 2001 & Ohio & Green Industry \\
\hline 2001 & Louisiana & Green Industry \\
\hline 2001 & Illinois & Green Industry \\
\hline 2001 & Florida & Environmental Horticulture Industry \\
\hline 2000 & Kansas & Horticulture Industry \\
\hline 2000 & Texas & Green Industry \\
\hline 2000 & Virginia & Turfgrass Industry \\
\hline 2000 & Maryland & Horticulture Industry \\
\hline 2000 & Missouri & Nursery Industry \\
\hline 2000 & Pennsylvania & Green Industry \\
\hline 1999 & South Carolina & Horticulture Industry \\
\hline 1999 & North Carolina & Turfgrass \\
\hline 1999 & Arizona & Green Industry \\
\hline 1999 & Wisconsin & Turfgrass Industry \\
\hline 1998 & Missouri & Turfgrass Industry \\
\hline 1998 & New England & Environmental Horticulture Industry \\
\hline 1997 & Florida & Environmental Horticultural Industry \\
\hline 1997 & Louisiana & Nursery and Turfgrass Industry \\
\hline 1996 & Maryland & Turfgrass Industry \\
\hline 1996 & Mississippi & Turfgrass Industry \\
\hline 1995 & New Mexico & Turfgrass Industry \\
\hline 1995 & Louisiana & Green Industry \\
\hline 1994 & Arizona & Green Industry \\
\hline 1994 & Kansas & Turfgrass Industry \\
\hline 1994 & North Carolina & Turfgrass Industry \\
\hline 1994 & South Carolina & Golf Industry \\
\hline 1994 & South Carolina & Ornamental Horticulture and Turfgrass Industry \\
\hline 1994 & Kansas & Horticulture Industry \\
\hline 1993 & Colorado & Green Industry \\
\hline 1993 & Texas & Green Industry \\
\hline 1993 & Tennessee & Nursery and Floriculture Industry \\
\hline 1991 & Florida & Turfgrass Industry \\
\hline 1990 & Michigan & Nursery and Landscape Industry \\
\hline 1989 & Ohio & Turfgrass Industry \\
\hline 1989 & Kentucky & Turfgrass Industry \\
\hline 1989 & Pennsylvania & Turfgrass Industry \\
\hline 1989 & Michigan & Turfgrass Industry \\
\hline 1987 & Oklahoma & Turfgrass Industry \\
\hline 1986 & North Carolina & Turfgrass Industry \\
\hline 1985 & New Jersey & Turfgrass Industry \\
\hline 1984 & Rhode Island & Turfgrass Industry \\
\hline 1982 & Virginia & Turfgrass Industry \\
\hline 1978 & Oklahoma & Turfgrass Industry \\
\hline
\end{tabular}

Source: Hall, Hodges and Haydu, 2005. 


\section{RESEARCH METHODOLOGY}

\section{Industry Sectors}

The economic sectors associated with the turfgrass and lawncare industry in the United States include sod farms, lawncare services, lawn and garden retail stores, lawn equipment manufacturing, and golf courses, as indicated in Table 2. Definitions of these sectors were based on the North American Industry Classification System (NAICS, Executive Office of the President, Office of Management and Budget), at the five or six-digit level of detail. The five sectors shown in Table 2 are major components of the turfgrass industry that were used in estimating economic impacts. However, it should be noted that they do not represent all the sectors that contribute to the value of the turf industry. There are other turf-based recreational activities, such as racetracks and athletic fields, which were not included in the analysis due to a lack of data to estimate their economic impact. Consequently, the impact values presented in this report for the turfgrass industry are considered a conservative estimate of the true value. In the same vein, it is also important to recognize that this study includes golf courses as part of the turfgrass industry's economic impact. Although it is logical to do so since turfgrass is a key input in golf operations, other aspects of golf operations are less directly attributable to turfgrass, such as restaurants or lodging establishments. In these activities, the economic role of turfgrass may be less clear and less significant. This qualifier is important given the economic significance of this particular sector.

Table 2. Classification of sectors associated with the turfgrass and lawncare industry.

\begin{tabular}{lll}
\hline \multicolumn{1}{c}{ Sector } & \multicolumn{1}{c}{ Industry Sector(s) (NAICS code) } & \multicolumn{1}{c}{ Implan Sector Name (Number) } \\
\hline Sod Farms & Nursery and Floriculture Production (11142)* & Nursery \& Greenhouse (6) \\
Lawncare Services & Landscaping Services (56173)* & Services To Buildings And Dwellings (458) \\
Lawncare Retail & Lawn and Garden Equipment and Supplies & Building Material And Garden Supply Stores \\
Stores & Stores (4442)* and Home Centers (44411)* & $(404)$ \\
Lawn Equipment & Lawn \& Garden Tractor and Home Lawn and & Lawn \& Garden Equipment Manufacturing (258) \\
Manufacturing & Garden Equipment Manufacturing (333112)* & Amusement, Gambling and Recreation Services \\
Golf Courses & Golf Courses and Country Clubs (71391) & (458) \\
\hline
\end{tabular}

* Turfgrass-related activity in this sector is a portion of the overall industry sector.

\section{Information Sources}

Economic information on the turfgrass industry was compiled from a variety of sources. The Census of Agriculture and Economic Census were considered to be the most reliable information sources available since they have well-established statistical methodologies with adjustment for small or non-responding firms and provide published confidence parameters.

For sod farms, national and state information on number of farms and production area were taken from the Census of Agriculture for 2002. Area and value of turfgrass harvested were estimated from industry survey data, with harvest value based on regional average prices. In this survey, a total of 581 sod farms were sent questionnaires of which 159 were returned, for a response rate of 27 percent. To determine value, respondents were asked their production area, percent of area harvested, average price (farm gate price, i.e., delivery not included), and share of total sales as sod products, and the share of sales that to customers outside their state.

For the sectors of lawncare services, retailing, equipment manufacturing and golf courses, information on number of establishments, employment, and sales (receipts) were taken from the 2002 Economic Census Industry Report Series for U.S. totals (U.S. Census Bureau, 2005). State-level information on number of firms, employment and payroll were taken from County Business Patterns (U.S. Department of Commerce), and were adjusted to match the U.S. totals. For some states in which employment and wages were non-disclosed because of a small number of firms reporting, employment was estimated at the midpoint of the range indicated, and payroll was estimated at the national average annual wages per employee.

Information on specific lawncare-related landscape services was taken from Dun \& Bradstreet (Dun and Bradstreet Information Systems, 1997). A total of 18 specialty sectors were delineated representing over 53 
thousand establishments nationwide. For the activities of lawn and garden services, garden maintenance and planting services, and landscape contractors, the share of total revenues that were turfgrass-related was estimated at 29.5 percent, based on data from the Economic Census. Retail sales of lawncare goods were taken from the National Gardening Survey for 2002, which was conducted by Harris Interactive for the National Gardening Association (Butterfield, 2005). Sales of lawncare goods amounted to \$11.96 Bn in 2002, which represented 30.2 percent of total U.S. household retail lawn and garden expenditures (\$39.64 Bn). Information on manufacturing of specific lawn equipment was taken from the Current Industrial Report on Farm Machinery and Lawn and Garden Equipment Manufacturing (U.S. Census Bureau, 2003b). Lawn equipment was segregated into six different categories, accounting for a total of \$6.15 billion in sales in 2003.

\section{Economic Impact Analysis}

To evaluate the broad regional economic impacts of the turfgrass and lawncare industry in the United States, regional economic models were developed for each state using the Implan software system and associated state datasets (MIG, Inc., 2004). The Implan system includes over 500 distinct industry sectors. The Implan data used for this analysis was based on fiscal year 2001. The information for these models was derived from the U.S. National Income and Product Accounts, together with regional economic data collected by the U.S. Department of Commerce, Bureau of Economic Analysis. Input-output models represent the structure of a regional economy in terms of transactions between industries, employees, households, and government institutions (Miller and Blair, 1985).

Economic multipliers derived from the models were used to estimate the total economic activity generated in each state by sales (or output) to final demand or exports. This includes the effects of intermediate purchases by industry firms from other economic sectors (indirect effects) and the effects of industry employee household consumer spending (induced effects), in addition to direct sales by industry firms. The regional Implan models were constructed as fully closed models, with all household, government, and capital accounts treated as endogenous, to derive Social Accounting Matrix (SAM) type multipliers, which represent transfer payments as well as earned income. Separate multipliers are provided for output (sales), employment, value added, labor income, and business taxes. The sectors used in the Implan models are indicated in Table 2 and the multipliers for each industry sector and state are shown in Appendix A. The multipliers for output, value added, labor income, and indirect business taxes are expressed in units of dollars per dollar output, while the employment multiplier is expressed in jobs per million dollars output. Differences in values of the multipliers reflect the structure of industry sectors and regional mix of supplier industries. The multipliers were applied to estimated industry sales or output in order to estimate total economic impacts. For the producer, manufacturer, service, and golf course sectors, total economic impacts were estimated as:

$$
I_{h i j}=S_{h i} x\left[A_{h i j}+E_{h i} \times\left(B_{h i j}+C_{h i j}\right)\right]
$$

while impacts for the retail trade sectors were estimated as:

$$
I_{h i j}=S_{h i} x G_{i}\left[A_{h i j}+B_{h i j}+C_{h i j}\right] \text {, }
$$

where:

$\mathrm{I}_{\text {hij }}$ is total impact for measures (j) of output, employment, value added, labor income, or indirect business taxes, in each sector (i), and state (h).

$\mathrm{S}_{\mathrm{hi}}$ is industry sales in sector $\mathrm{i}$ and state $\mathrm{h}$.

$E_{h i}$ is the proportion of industry sales exported or shipped outside the state, by sector $\mathrm{i}$ in state $\mathrm{h}$.

$A_{\text {hij }}$ is the direct effects multiplier for measure $\mathrm{j}$ in sector $\mathrm{i}$ and state $\mathrm{h}$.

$B_{\text {hij }}$ is the indirect effects multiplier for measure $j$ in sector $i$ and state $h$.

$\mathrm{C}_{\mathrm{hij}}$ is the induced effects multiplier for measure $\mathrm{j}$ in sector $\mathrm{i}$ and state $\mathrm{h}$.

$G_{i}$ is the gross margin on retail sales for sector $i$.

The calculation for the producer and service sectors assumes that only the export portion of output is sold to final demand and, therefore, is subject to the indirect and induced effects multipliers, while the remainder of in-state sales is subject to intermediate demand from other business sectors and to direct effects multipliers. Data on exports were taken from the Implan database for 2001 or 1999, except in the case of the nursery and greenhouse sector, where information for some states was taken from a national nursery industry survey 
(Brooker, et al, 2005). The calculation for the retail lawn and garden store sector assumed output is reduced to reflect only the gross margin on sales (29.5 percent) according to national averages (U.S. Census Bureau, 2004b). In some cases, impact results for 2002 values were restated 7.36 percent higher to express in current dollars terms, using the Gross Domestic Product (GDP) Implicit Price Deflator (U.S. Dept. Commerce, 2005) for April 2002 and April 2005.

\section{RESULTS}

\section{National Results for All Industry Sectors}

Total economic impacts of the five major sectors of the turfgrass industry in 2002 are summarized in Table 3. Total output or revenue impacts were estimated at $\$ 57.94$ billion ( $\mathrm{Bn})$. Total value added or net income impacts were \$35.07 Bn, including labor (earned) income of \$23.04 Bn. Whereas “total output impacts” is a gross figure, value added is a "net" estimate in that it basically subtracts out the Cost of Goods Sold (COGS) from gross output. Total employment impacts were 822,848 jobs, including both fulltime and part-time positions. Economic activity in the turfgrass industry also remunerated $\$ 2.42 \mathrm{Bn}$ in indirect business taxes to local and state governments. When these impact estimates for 2002 are adjusted for inflation to express in 2005 dollars, the total output impact is $\$ 62.20 \mathrm{Bn}$, the total value added impact is $\$ 37.65 \mathrm{Bn}$, the total labor income impact is $\$ 24.73 \mathrm{Bn}$, and the indirect business tax impact is $\$ 2.60 \mathrm{Bn}$. Other results in this report may be adjusted for inflation by multiplying 2002-dollar values by 1.0736 .

Table 3. Summary of economic impacts of the turfgrass and lawncare industry in the United States, by sector, 2002.

\begin{tabular}{|c|c|c|c|c|c|c|c|c|}
\hline \multirow{2}{*}{ Sector } & \multicolumn{4}{|c|}{ Output } & \multirow{2}{*}{$\begin{array}{l}\text { Value } \\
\text { Added } \\
\text { (Mn\$) }\end{array}$} & \multirow{2}{*}{$\begin{array}{l}\text { Labor } \\
\text { Income } \\
\text { (Mn\$) }\end{array}$} & \multirow{2}{*}{$\begin{array}{c}\text { Indirect } \\
\text { Business } \\
\text { Tax } \\
\text { (Mn\$) }\end{array}$} & \multirow{2}{*}{$\begin{array}{c}\text { Employ- } \\
\text { ment } \\
\text { (jobs) }\end{array}$} \\
\hline & $\begin{array}{l}\text { Total } \\
\text { (Mn\$) }\end{array}$ & $\begin{array}{l}\text { Direct } \\
(\mathrm{Mn} \$)\end{array}$ & $\begin{array}{l}\text { Indirect } \\
(\mathrm{Mn} \$)\end{array}$ & $\begin{array}{l}\text { Induced } \\
(\mathrm{Mn} \$)\end{array}$ & & & & \\
\hline Sod Production & $1,669.6$ & $1,494.5$ & 28.9 & 146.2 & $1,266.3$ & 585.8 & 27.2 & 17,028 \\
\hline Lawncare Services & $18,506.9$ & $12,811.5$ & $1,013.4$ & $4,681.9$ & $12,425.1$ & $9,684.5$ & 458.4 & 295,841 \\
\hline Lawncare Retailing & $8,473.7$ & $3,529.1$ & 922.9 & $4,021.8$ & $5,483.1$ & $3,615.3$ & 671.2 & 114,294 \\
\hline $\begin{array}{l}\text { Lawn Equipment } \\
\text { Manufacturing }\end{array}$ & $7,513.7$ & $6,148.4$ & 613.4 & 756.6 & $2,364.7$ & $1,224.3$ & 117.3 & 33,995 \\
\hline Golf Courses & $21,772.3$ & $17,433.8$ & 941.8 & $3,396.7$ & $13,532.2$ & $7,926.7$ & $1,145.6$ & 361,690 \\
\hline Total & $57,936.2$ & $41,417.3$ & $3,520.4$ & $13,003.2$ & $35,071.5$ & $23,036.7$ & $2,419.7$ & 822,848 \\
\hline
\end{tabular}

As explained previously, the total economic impact is comprised of direct, indirect and induced components. Direct output impacts, representing sales by the turfgrass industry sectors, amounted to $\$ 41.42 \mathrm{Bn}$, indirect output impacts were $\$ 3.52 \mathrm{Bn}$., representing the value of purchased goods and services by the turfgrass industry, and induced impacts were $\$ 13.00 \mathrm{Bn}$, arising from consumer spending by industry employees (Table 3).

Individually, the five sectors of the turfgrass industry each contributed substantially to the total impacts. Sod producers created nearly $\$ 1.67$ billion in gross output, representing roughly 3 percent of the total industry. Although this sector's share of revenue is relatively small due to its "product" rather than "service" orientation, its importance lies with the economic activity that is generated throughout the rest of the system. Without sod producers there would be less demand for lawncare services, retailing, and equipment manufacturing, particularly in the warmer southern states where seed is rarely used. Lawn equipment manufacturers, which also primarily offer a product rather than a service, contributed $\$ 7.51 \mathrm{Bn}$ in total output, accounting for 13 percent industry share. Lawncare retailing was the third largest sector contributing \$8.47 $\mathrm{Bn}$ in total output, representing nearly 15 percent share. Lawncare services were estimated to have generated $\$ 18.51 \mathrm{Bn}$ in output impacts, representing nearly one-third share. Golf courses comprised the largest single component of gross output, $\$ 21.77 \mathrm{Bn}$ or 37 percent of the industry. The last two sectors — lawncare services and golf courses — are 
heavily weighted towards value added services and, consequently, account for the greatest share of economic impacts.

For employment impacts of the turfgrass industry, 44 percent of jobs $(361,690)$ were derived from golf courses, 36 percent from lawn care services (295,841), 14 percent from lawncare retailing $(114,294), 4$ percent from lawn equipment manufacturing, and 2 percent by the sod production industry (Figure 3 ). This employment created $\$ 23.0 \mathrm{Bn}$ in labor income and paid $\$ 2.4$ billion in indirect business taxes. Labor income contributes to economic activity by creating demand as employees spend their earnings on other goods and services such as food, housing, clothes, and recreational pursuits. Although "jobs created” and labor income are crucial measures of economic activity, by themselves they do not tell the entire story of an industry's contribution to society. As will be shown later, a sector can have low employment levels but, because of its high product value, service value or regional trade value, still contribute substantially to a local or national economy.

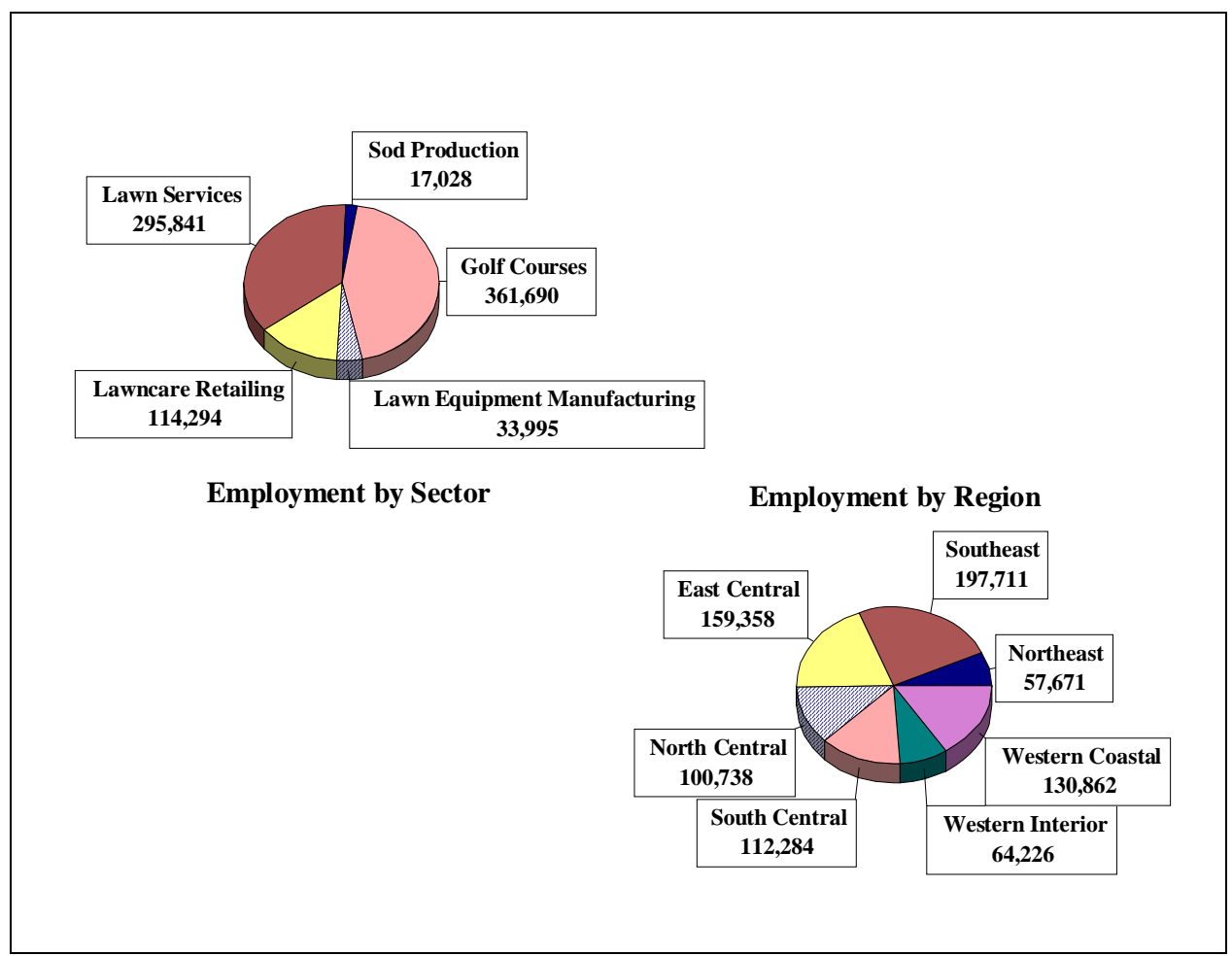

Figure 2. Employment impacts of the U.S. turfgrass and lawncare industry, by sector and region, 2002.

\section{State and Regional Impacts}

Employment and value added impacts of the turfgrass industry are summarized by sector, state and region in Table 4. Seven regions were defined for this study: 1) Northeast - Connecticut, Maine, Massachusetts, New Hampshire, New York, Rhode Island, and Vermont; 2) Southeast — Alabama, Florida, Georgia, North Carolina, South Carolina, and Tennessee; 3) East Central — Delaware, Kentucky, Maryland, Michigan, New Jersey, Ohio, Pennsylvania, Virginia, and West Virginia; 4) North Central — Illinois, Indiana, Iowa, Minnesota, Nebraska, North Dakota, South Dakota, and Wisconsin; 5) South Central - Arkansas, Kansas, Louisiana, Mississippi, Missouri, Oklahoma, and Texas; 6) Western Interior - Arizona, Colorado, Idaho, Montana, Nevada, New Mexico, Utah, and Wyoming; and 7) Western Coastal — Alaska, California, Hawaii, Oregon, and Washington.

Of the seven regions, the Southeast comprised the largest share of total employment with roughly onequarter $(197,711)$ of all jobs and 22 percent $(\$ 7.9 \mathrm{Bn})$ of value added impacts. It should be noted, however, that these rankings are based on total impacts only and that considerable variation exists across regions when discussing the five turfgrass sectors. For instance, the Southeast was first in sod production and equipment manufacturing, but fifth in lawncare retailing. Similarly, the North Central region was ranked fifth overall, but was second in equipment manufacturing. This indicates that product or service specialization varies considerably across regions. The East Central region, constituting 19 percent of total employment and 20 
percent of value added, was a close second in regional rankings. In third place was the Western Coastal region accounting for 16 percent of employment impacts and 15 percent of value added. South Central region was ranked fourth with 14 percent share of employment and 11 percent in value added. Rankings for remaining regions were North Central ( $5^{\text {th }}$ place), Western Interior $\left(6^{\text {th }}\right)$, and the Northeast $\left(7^{\text {th }}\right)$.

The top ten individual states in terms of employment impacts were California (101,022 jobs), Florida $(83,944)$, Texas $(52,784)$, Ohio $(33,154)$, Illinois $(31,625)$, Pennsylvania $(30,845)$, North Carolina $(28,860)$, Georgia $(27,327)$, South Carolina $(25,083)$ and New York $(23,965)$.

Table 4. Employment and value added impacts of the U.S. turfgrass and lawncare industry by state, region and industry group, 2002.

\begin{tabular}{|c|c|c|c|c|c|c|c|c|c|c|c|c|}
\hline \multirow[b]{2}{*}{ State/Region } & \multicolumn{6}{|c|}{ Employment Impacts (jobs) } & \multicolumn{6}{|c|}{ Value Added Impacts (Mn\$) } \\
\hline & $\begin{array}{c}\text { Sod } \\
\text { Pro- } \\
\text { duction }\end{array}$ & $\begin{array}{l}\text { Lawn } \\
\text { Services }\end{array}$ & $\begin{array}{l}\text { Lawncare } \\
\text { Retailing }\end{array}$ & $\begin{array}{l}\text { Eqmt. } \\
\text { Manuf. }\end{array}$ & $\begin{array}{l}\text { Golf } \\
\text { Courses }\end{array}$ & Total & $\begin{array}{l}\text { Sod Pro- } \\
\text { duction }\end{array}$ & $\begin{array}{l}\text { Lawn } \\
\text { Services }\end{array}$ & $\begin{array}{l}\text { Lawncare } \\
\text { Retailing }\end{array}$ & $\begin{array}{l}\text { Eqmt. } \\
\text { Manuf. }\end{array}$ & $\begin{array}{c}\text { Golf } \\
\text { Courses }\end{array}$ & Total \\
\hline Total U.S. & 17,028 & 295,841 & 114,294 & 33,995 & 361,690 & 822,849 & $1,266.3$ & $12,425.1$ & $5,483.1$ & $2,364.7$ & $13,532.2$ & $35,071.5$ \\
\hline Northeast & 558 & 22,053 & 7,814 & 741 & 26,505 & 57,671 & 36.6 & $1,253.5$ & 424.7 & 57.1 & $1,424.1$ & $3,196.0$ \\
\hline Connecticut & 61 & 4,399 & 1,233 & 0 & 4,257 & 9,950 & 4.8 & 259.1 & 72.7 & 0.0 & 216.6 & 553.3 \\
\hline Maine & 62 & 1,210 & 524 & 10 & 909 & 2,715 & 3.6 & 51.4 & 21.8 & 0.7 & 44.8 & 122.3 \\
\hline Massachusetts & 30 & 6,038 & 1,390 & 0 & 6,576 & 14,033 & 1.0 & 371.0 & 80.8 & 0.0 & 342.0 & 794.8 \\
\hline New Hampshire & 9 & 1,401 & 523 & 0 & 1,156 & 3,089 & 0.3 & 68.2 & 26.5 & 0.0 & 70.0 & 165.1 \\
\hline New York & 248 & 7,540 & 3,666 & 722 & 11,789 & 23,965 & 20.5 & 425.9 & 201.6 & 55.7 & 653.1 & $1,356.8$ \\
\hline Rhode Island & 148 & 954 & 80 & 0 & 1,555 & 2,737 & 6.2 & 52.7 & 4.0 & 0.0 & 75.8 & 138.7 \\
\hline Vermont & 0 & 511 & 398 & 10 & 263 & 1,181 & 0.0 & 25.2 & 17.2 & 0.8 & 21.8 & 65.0 \\
\hline Southeast & 7,261 & 62,508 & 16,762 & 13,414 & 97,766 & 197,711 & 615.0 & $2,262.5$ & 798.9 & 867.4 & 3,353.4 & 7,897.3 \\
\hline Alabama & 1,115 & 4,177 & 1,329 & 59 & 5,354 & 12,033 & 102.4 & 141.5 & 56.8 & 4.3 & 159.0 & 464.0 \\
\hline Florida & 3,544 & 25,281 & 4,114 & 67 & 50,938 & 83,944 & 294.3 & 895.2 & 200.0 & 3.7 & $1,926.5$ & $3,319.7$ \\
\hline Georgia & 761 & 10,290 & 3,333 & 2,409 & 10,534 & 27,327 & 99.5 & 393.8 & 176.2 & 155.1 & 325.2 & $1,149.7$ \\
\hline North Carolina & 265 & 11,390 & 3,487 & 355 & 13,362 & 28,860 & 43.7 & 409.8 & 159.1 & 31.6 & 398.0 & $1,042.2$ \\
\hline South Carolina & 651 & 6,017 & 1,427 & 5,211 & 11,777 & 25,083 & 55.7 & 211.8 & 63.0 & 318.8 & 349.4 & 998.6 \\
\hline Tennessee & 926 & 5,353 & 3,071 & 5,313 & 5,801 & 20,463 & 19.3 & 210.5 & 143.8 & 354.0 & 195.3 & 923.1 \\
\hline East Central & 2,092 & 62,670 & 23,065 & 3,618 & 67,913 & 159,358 & 125.6 & $2,790.9$ & $1,109.2$ & 292.2 & $2,642.4$ & $6,960.3$ \\
\hline Delaware & 41 & 1,238 & 271 & 0 & 1,308 & 2,858 & 7.2 & 48.1 & 13.1 & 0.0 & 48.5 & 116.8 \\
\hline Kentucky & 237 & 2,271 & 2,348 & 7 & 3,528 & 8,390 & 13.6 & 80.5 & 100.2 & 0.5 & 105.1 & 299.8 \\
\hline Maryland & 145 & 8,924 & 2,082 & 10 & 5,896 & 17,056 & 14.6 & 407.5 & 109.2 & 0.8 & 225.9 & 758.0 \\
\hline Michigan & 317 & 6,820 & 3,332 & 522 & 10,925 & 21,916 & 17.2 & 370.3 & 165.4 & 65.2 & 588.6 & $1,206.6$ \\
\hline New Jersey & 583 & 9,200 & 1,653 & 54 & 7,231 & 18,722 & 33.6 & 472.9 & 96.7 & 4.8 & 349.2 & 957.2 \\
\hline Ohio & 318 & 12,821 & 4,515 & 2,117 & 13,383 & 33,154 & 17.8 & 516.9 & 203.2 & 152.1 & 482.3 & $1,372.1$ \\
\hline Pennsylvania & 74 & 10,067 & 4,578 & 166 & 15,960 & 30,845 & 5.1 & 454.1 & 219.7 & 15.3 & 548.8 & $1,243.0$ \\
\hline Virginia & 363 & 10,370 & 3,781 & 741 & 8,440 & 23,694 & 16.4 & 408.6 & 182.3 & 53.6 & 256.1 & 917.0 \\
\hline West Virginia & 14 & 960 & 505 & 0 & 1,243 & 2,723 & 0.1 & 32.2 & 19.5 & 0.0 & 38.0 & 89.8 \\
\hline North Central & 1,166 & 27,875 & 22,541 & 9,604 & 39,552 & 100,738 & 93.0 & $1,426.3$ & $1,025.1$ & 749.1 & $1,608.8$ & $4,902.2$ \\
\hline Illinois & 237 & 10,303 & 5,218 & 1,819 & 14,049 & 31,625 & 22.2 & 623.9 & 267.8 & 140.4 & 612.7 & $1,666.9$ \\
\hline Indiana & 169 & 5,907 & 3,568 & 1,133 & 8,053 & 18,831 & 12.3 & 249.4 & 157.4 & 74.9 & 311.8 & 805.7 \\
\hline Iowa & 117 & 1,754 & 2,797 & 124 & 4,551 & 9,343 & 9.8 & 69.6 & 117.4 & 7.1 & 161.8 & 365.7 \\
\hline Minnesota & 424 & 3,910 & 3,352 & 1,037 & 3,868 & 12,590 & 31.9 & 201.3 & 161.2 & 75.1 & 195.7 & 665.2 \\
\hline Nebraska & 61 & 1,116 & 2,087 & 87 & 2,058 & 5,408 & 5.9 & 45.1 & 84.6 & 6.2 & 64.1 & 205.9 \\
\hline North Dakota & 1 & 188 & 631 & 9 & 255 & 1,084 & 0.0 & 7.0 & 23.8 & 0.7 & 11.7 & 43.2 \\
\hline South Dakota & 4 & 278 & 1,029 & 11 & 804 & 2,126 & 0.4 & 8.8 & 39.4 & 0.9 & 31.7 & 81.2 \\
\hline Wisconsin & 154 & 4,418 & 3,861 & 5,383 & 5,915 & 19,731 & 10.5 & 221.1 & 173.5 & 443.9 & 219.3 & $1,068.4$ \\
\hline South Central & 4,085 & 34,481 & 21,117 & 4,932 & 47,669 & 112,284 & 222.6 & $1,188.0$ & 954.1 & 273.4 & $1,450.9$ & $4,089.1$ \\
\hline Arkansas & 347 & 1,671 & 1,488 & 2,511 & 2,642 & 8,659 & 32.7 & 53.9 & 57.1 & 122.6 & 70.4 & 336.6 \\
\hline Kansas & 107 & 2,234 & 2,092 & 475 & 3,399 & 8,307 & 9.2 & 86.1 & 88.1 & 34.4 & 100.8 & 318.6 \\
\hline Louisiana & 132 & 1,931 & 1,879 & 10 & 4,927 & 8,879 & 8.0 & 55.2 & 78.1 & 0.7 & 162.4 & 304.3 \\
\hline Mississippi & 222 & 1,259 & 1,472 & 1,023 & 3,355 & 7,331 & 17.2 & 37.1 & 57.5 & 59.6 & 101.9 & 273.3 \\
\hline Missouri & 308 & 4,238 & 4,055 & 815 & 7,799 & 17,214 & 13.7 & 157.3 & 185.4 & 49.6 & 296.8 & 702.7 \\
\hline
\end{tabular}




\begin{tabular}{|c|c|c|c|c|c|c|c|c|c|c|c|c|}
\hline \multirow[b]{2}{*}{ State/Region } & \multicolumn{6}{|c|}{ Employment Impacts (jobs) } & \multicolumn{6}{|c|}{ Value Added Impacts (Mn\$) } \\
\hline & $\begin{array}{l}\text { Sod } \\
\text { Pro- } \\
\text { duction }\end{array}$ & $\begin{array}{l}\text { Lawn } \\
\text { Services }\end{array}$ & $\begin{array}{l}\text { Lawncare } \\
\text { Retailing }\end{array}$ & $\begin{array}{c}\text { Eqmt. } \\
\text { Manuf. }\end{array}$ & $\begin{array}{c}\text { Golf } \\
\text { Courses }\end{array}$ & Total & $\begin{array}{l}\text { Sod Pro- } \\
\text { duction }\end{array}$ & $\begin{array}{c}\text { Lawn } \\
\text { Services }\end{array}$ & $\begin{array}{l}\text { Lawncare } \\
\text { Retailing }\end{array}$ & $\begin{array}{l}\text { Eqmt. } \\
\text { Manuf. }\end{array}$ & $\begin{array}{c}\text { Golf } \\
\text { Courses }\end{array}$ & Total \\
\hline Oklahoma & 993 & 3,037 & 1,862 & 61 & 3,159 & 9,110 & 42.7 & 69.7 & 75.3 & 4.4 & 81.4 & 273.4 \\
\hline Texas & 1,976 & 20,113 & 8,270 & 38 & 22,388 & 52,784 & 99.1 & 728.9 & 412.7 & 2.2 & 637.2 & $1,880.0$ \\
\hline $\begin{array}{l}\text { Western } \\
\text { Interior }\end{array}$ & 975 & 26,371 & 8,459 & 913 & 27,507 & 64,226 & 104.0 & $1,057.9$ & 393.4 & 63.8 & $1,042.3$ & $2,661.5$ \\
\hline Arizona & 109 & 9,164 & 1,612 & 892 & 11,120 & 22,897 & 15.3 & 324.6 & 77.1 & 62.3 & 339.3 & 818.6 \\
\hline Colorado & 287 & 7,133 & 2,132 & 11 & 5,320 & 14,883 & 28.5 & 328.0 & 111.7 & 0.7 & 267.3 & 736.2 \\
\hline Idaho & 190 & 1,401 & 1,390 & 0 & 1,255 & 4,236 & 25.1 & 54.5 & 61.2 & 0.0 & 43.5 & 184.3 \\
\hline Montana & 47 & 366 & 887 & 0 & 1,025 & 2,325 & 3.8 & 13.6 & 33.9 & 0.0 & 43.2 & 94.5 \\
\hline Nevada & 31 & 4,959 & 503 & 0 & 5,379 & 10,872 & 3.9 & 213.0 & 26.9 & 0.0 & 231.9 & 475.7 \\
\hline New Mexico & 45 & 1,322 & 631 & 0 & 1,171 & 3,169 & 5.9 & 42.1 & 26.2 & 0.0 & 30.7 & 105.0 \\
\hline Utah & 245 & 1,744 & 1,072 & 11 & 1,758 & 4,830 & 19.8 & 68.3 & 46.9 & 0.8 & 69.1 & 204.8 \\
\hline Wyoming & 21 & 280 & 233 & 0 & 479 & 1,013 & 1.9 & 13.9 & 9.3 & 0.0 & 17.3 & 42.4 \\
\hline $\begin{array}{l}\text { Western } \\
\text { Coastal }\end{array}$ & 893 & 59,884 & 14,536 & 772 & 54,777 & 130,862 & 69.6 & $2,445.9$ & 777.8 & 61.6 & $2,010.2$ & $5,365.1$ \\
\hline Alaska & 4 & 173 & 96 & 0 & 77 & 350 & 0.3 & 10.9 & 4.7 & 0.0 & 2.9 & 18.9 \\
\hline California & 553 & 48,547 & 9,370 & 693 & 41,858 & 101,022 & 48.7 & $1,971.8$ & 525.2 & 56.2 & 1,539.9 & $4,141.7$ \\
\hline Hawaii & 7 & 1,653 & 216 & 0 & 3,848 & 5,724 & 0.4 & 65.0 & 10.6 & 0.0 & 152.5 & 228.5 \\
\hline Oregon & 154 & 3,556 & 2,113 & 62 & 3,610 & 9,495 & 7.0 & 141.8 & 97.8 & 4.0 & 124.1 & 374.7 \\
\hline Washington & 174 & 5,954 & 2,742 & 17 & 5,383 & 14,270 & 13.2 & 256.4 & 139.5 & 1.5 & 190.8 & 601.3 \\
\hline
\end{tabular}

\section{The Sod Production Sector}

The sod and seed production sector is the beginning of the market chain for the turfgrass industry. According to the 2002 Census of Agriculture, a total of 2,124 sod production firms were in operation in 2002 (USDA, 2004), as summarized in Table 5. Of the top 10 states, two stood out in terms of farm numbers: Florida with 235 and Texas with 205. A second tier with roughly half these farm numbers was Alabama (96), Oklahoma (95), Georgia (92), Minnesota (89), and North Carolina (87). A third tier included Wisconsin (63), California (62), and Ohio (62). Altogether the top 10 states comprised just over half of all firms in the United States. Census figures show a total of 386,505 acres in production in 2002 of which roughly two-thirds (250,432 acres) were harvested and sold. Other characteristics of sod production, including percent of area harvested, average product prices, and share of sales outside the state, are summarized regionally from survey data in Table 6.

When ranking the top 10 states in terms of total economic impact for sod production, four tiers are readily apparent. Florida clearly held the top tier with nearly 20 percent of the U.S. total, or \$319 Mn (Figure 3). Texas was alone in the second tier with $\$ 168 \mathrm{Mn}$ in total gross output. Together these two states accounted for nearly one-third (30\%) of total U.S. output impact. Alabama at \$108 Mn and Georgia with \$106 Mn in output impacts were closely tied for third and fourth place, representing the third tier. The fourth tier consisted of Oklahoma ( $\$ 77 \mathrm{Mn}$ ), California ( $\$ 70 \mathrm{Mn}$ ), Minnesota ( $\$ 65 \mathrm{Mn})$, South Carolina (\$59 Mn), Colorado (\$47 $\mathrm{Mn}$ ), and North Carolina (\$46 Mn). All totaled, the top 10 states accounted for \$1.06 Bn or 64 percent of output impacts generated in the United States. When comparing state-level firm numbers discussed in the first paragraph, and economic impacts in this paragraph, a fairly strong correlation between farm numbers and value is apparent. However, it is important not to over-generalize that more firms per state always result in greater impacts. For instance, Wisconsin and Ohio were ranked in the top 10 states with regard to number of firms, but were not in the top ten with regard to economic impacts, where they were replaced by Colorado and South Carolina. As will be seen later, much depends on the value of the product or service supplied by a particular industry. Lawn-equipment manufacturers, for instance, are relatively few compared to other turfgrass sectors, but they represent considerable economic value because of the high cost of equipment they produce. 
Table 5. U.S. sod farms, production area and harvested area, 2002

\begin{tabular}{|c|c|c|c|}
\hline State & Farms & $\begin{array}{l}\text { Production Area in } \\
\text { the Open (Acres) }\end{array}$ & $\begin{array}{c}\text { Harvested } \\
\text { Area (Acres)* }\end{array}$ \\
\hline Alabama & 96 & 25,805 & 17,057 \\
\hline Alaska & 2 & 130 & 86 \\
\hline Arizona & 13 & 3,187 & 1,689 \\
\hline Arkansas & 58 & 8,998 & 5,948 \\
\hline California & 62 & 15,909 & 10,516 \\
\hline Colorado & 48 & 7,767 & 4,117 \\
\hline Connecticut & 10 & 1,251 & 609 \\
\hline Delaware & 6 & 2,305 & 1,044 \\
\hline Florida & 235 & 92,990 & 62,836 \\
\hline Georgia & 92 & 24,653 & 16,296 \\
\hline Hawaii & 20 & 113 & 75 \\
\hline Idaho & 38 & 4,704 & 2,493 \\
\hline Illinois & 40 & 7,994 & 3,893 \\
\hline Indiana & 38 & 5,076 & 2,472 \\
\hline Iowa & 33 & 4,836 & 2,355 \\
\hline Kansas & 49 & 4,971 & 3,286 \\
\hline Kentucky & 54 & 4,692 & 2,125 \\
\hline Louisiana & 23 & 2,747 & 1,816 \\
\hline Maine & 10 & 1,151 & 561 \\
\hline Maryland & 29 & 4,987 & 2,259 \\
\hline Massachusetts & 6 & 390 & 190 \\
\hline Michigan & 54 & 10,262 & 4,649 \\
\hline Minnesota & 89 & 14,564 & 7,093 \\
\hline Mississippi & 47 & 4,352 & 2,877 \\
\hline Missouri & 53 & 6,002 & 3,967 \\
\hline Montana & 16 & 1,232 & 653 \\
\hline Nebraska & 38 & 3,015 & 1,468 \\
\hline Nevada & 11 & 720 & 382 \\
\hline New Hampshire & 2 & 130 & 63 \\
\hline New Jersey & 53 & 12,485 & 5,656 \\
\hline New Mexico & 5 & 1,186 & 629 \\
\hline New York & 14 & 6,868 & 3,345 \\
\hline North Carolina & 87 & 10,952 & 7,239 \\
\hline North Dakota & 3 & 27 & 13 \\
\hline Ohio & 62 & 9,434 & 4,274 \\
\hline Oklahoma & 95 & 17,846 & 11,796 \\
\hline Oregon & 14 & 2,608 & 1,724 \\
\hline Pennsylvania & 24 & 2,100 & 951 \\
\hline Rhode Island & 15 & 2,453 & 1,195 \\
\hline South Carolina & 27 & 14,027 & 9,272 \\
\hline South Dakota & 3 & 195 & 95 \\
\hline Tennessee & 56 & 8,419 & 5,565 \\
\hline Texas & 205 & 38,341 & 25,343 \\
\hline Utah & 46 & 4,036 & 2,139 \\
\hline Vermont & 3 & 3 & 1 \\
\hline Virginia & 25 & 7,315 & 3,314 \\
\hline Washington & 41 & 3,756 & 2,483 \\
\hline West Virginia & 2 & 130 & 59 \\
\hline Wisconsin & 63 & 4,399 & 2,142 \\
\hline Wyoming & 9 & 610 & 323 \\
\hline Total U.S. & 2,124 & 386,504 & 250,432 \\
\hline
\end{tabular}

Source: 2002 Census of Agriculture, USDA, 2004.

*Estimated using harvest ratio information from survey data (see Table 6). 
Table 6. Characteristics of U.S. sod producers surveyed, by region.

\begin{tabular}{|c|c|c|c|c|c|c|c|}
\hline Region: States & $\begin{array}{l}\text { Sample } \\
\text { Size }\end{array}$ & $\begin{array}{c}\text { Number } \\
\text { Respon- } \\
\text { dents }\end{array}$ & $\begin{array}{l}\text { Production } \\
\text { Area } \\
\text { (Acres) }\end{array}$ & $\begin{array}{l}\text { Percent of } \\
\text { Area } \\
\text { Harvested }\end{array}$ & $\begin{array}{l}\text { Average } \\
\text { Weighted } \\
\text { Price } \\
(\$ / \mathrm{SqFt})\end{array}$ & $\begin{array}{c}\text { Share of } \\
\text { Total } \\
\text { Sales as } \\
\text { Sod } \\
\text { Products } \\
(\%) \\
\end{array}$ & $\begin{array}{c}\text { Share of } \\
\text { Sales } \\
\text { Outside } \\
\text { State } \\
(\%)\end{array}$ \\
\hline Northeast: Maine, New & & & & & & & \\
\hline $\begin{array}{l}\text { Hampshire, New York, } \\
\text { Rhode Island }\end{array}$ & 21 & 10 & 3,947 & 46.0 & 0.226 & 77.2 & 34.4 \\
\hline $\begin{array}{l}\text { East Central: Delaware, } \\
\text { Kentucky, Maryland, } \\
\text { Michigan, New Jersey, Ohio, } \\
\text { Pennsylvania, Virginia }\end{array}$ & 99 & 25 & 12,451 & 45.3 & 0.157 & 81.2 & 4.8 \\
\hline $\begin{array}{c}\text { Southeast: Alabama, Florida, } \\
\text { Georgia, North Carolina, } \\
\text { South Carolina, Tennessee }\end{array}$ & 206 & 72 & 114,090 & 63.0 & 0.132 & 90.4 & 9.5 \\
\hline $\begin{array}{l}\text { North Central: Illinois, Iowa, } \\
\text { Minnesota, Nebraska, } \\
\text { Wisconsin }\end{array}$ & 78 & 18 & 11,620 & 48.7 & 0.161 & 80.7 & 22.7 \\
\hline $\begin{array}{c}\text { South Central: Arkansas, Kansas, } \\
\text { Missouri, Texas, Oklahoma }\end{array}$ & 63 & 12 & 10,746 & 66.1 & 0.133 & 83.3 & 9.6 \\
\hline $\begin{array}{l}\text { Western Interior: Colorado, } \\
\text { Idaho, Montana, Nevada, } \\
\text { Utah, Wyoming }\end{array}$ & 65 & 12 & 4,725 & 53.0 & 0.215 & 84.8 & 14.7 \\
\hline $\begin{array}{c}\text { Western Coastal: California, } \\
\text { Oregon, Washington }\end{array}$ & 49 & 10 & 8,785 & 92.2 & 0.235 & 93.3 & 0.9 \\
\hline Total & 581 & 159 & 166,364 & & & & \\
\hline
\end{tabular}

Source: UF/IFAS Sod Producer Survey, 2005 (unpublished data).

Figure 4 illustrates the top 10 states in terms of employment impacts for sod production. Again, four tiers are discernable, with Florida holding the number one spot at 3,544 jobs. Texas is ranked second with 1,976 turfgrass-related jobs. A third tier is comprised of three states, Alabama with 1,115 jobs, Oklahoma with 993, and Tennessee with 926 employment positions. Five states comprised the fourth tier — Georgia, South Carolina, New Jersey, California, and Minnesota, with employment ranging from a high of 761 in the case of Georgia to a low of 424 for Minnesota. Altogether, the top 10 states accounted for 68 percent of total employment by the U.S. sod production sector.

Value added is an important measure of economic contribution because it represents the net income gain to a local, regional, or national economy due to the activity of a given sector. It is considered a net figure because all direct costs used in the production of the product or service has been subtracted from gross output. Thus, it is considered an unbiased indicator of economic importance. The top 10 states accounted for over twothirds of the $\$ 1.27 \mathrm{Bn}$ in value added for the U.S. sod production industry (Figure 7). Florida dominated with \$294 Mn, followed by three states - Alabama (\$102 Mn), Georgia (\$100 Mn), and Texas with (\$99 Mn). A third tier is comprised of South Carolina, California, North Carolina, Oklahoma, New Jersey, and Arkansas. Within this group, value added ranged from a high of \$56 Mn for South Carolina to a low of \$33 Mn for Arkansas. Again it is important to recognize that rankings in one category, such as employment or number of firms, do not guarantee a similar ranking with other indicators. For example, with value added, Alabama replaces Texas for second place and, for the first time, New Jersey reaches the top 10 status. 


\section{Total Output Impacts (\$Mn)}

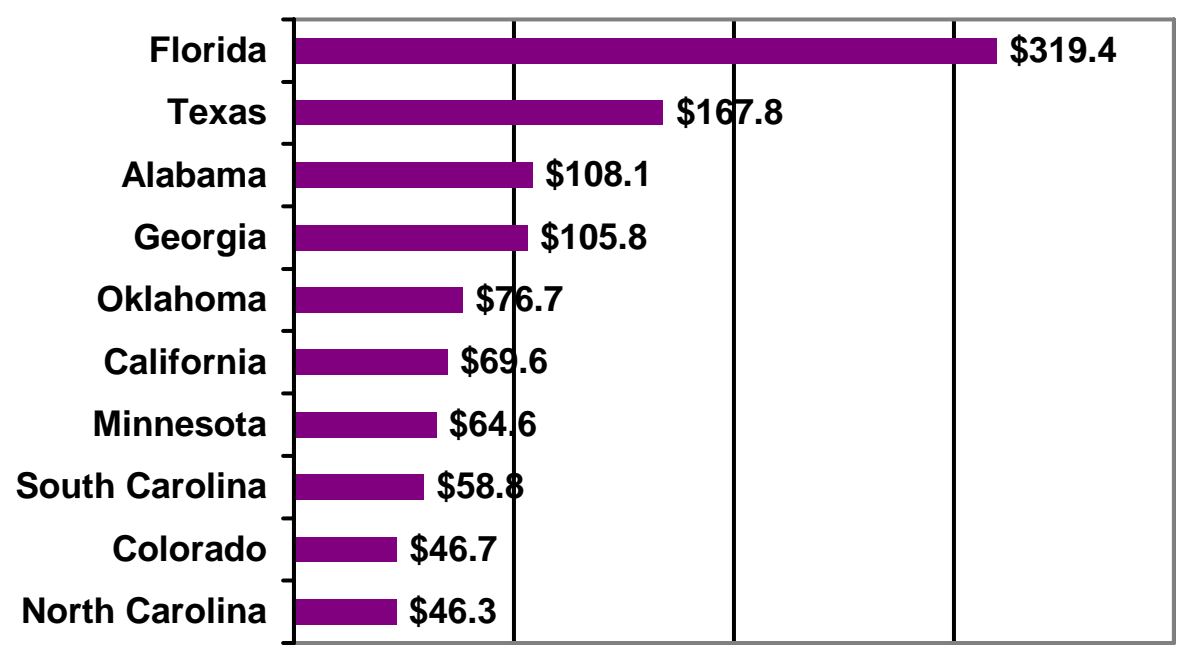

Figure 3. Top ten states for output impacts of the sod production sector, 2002.

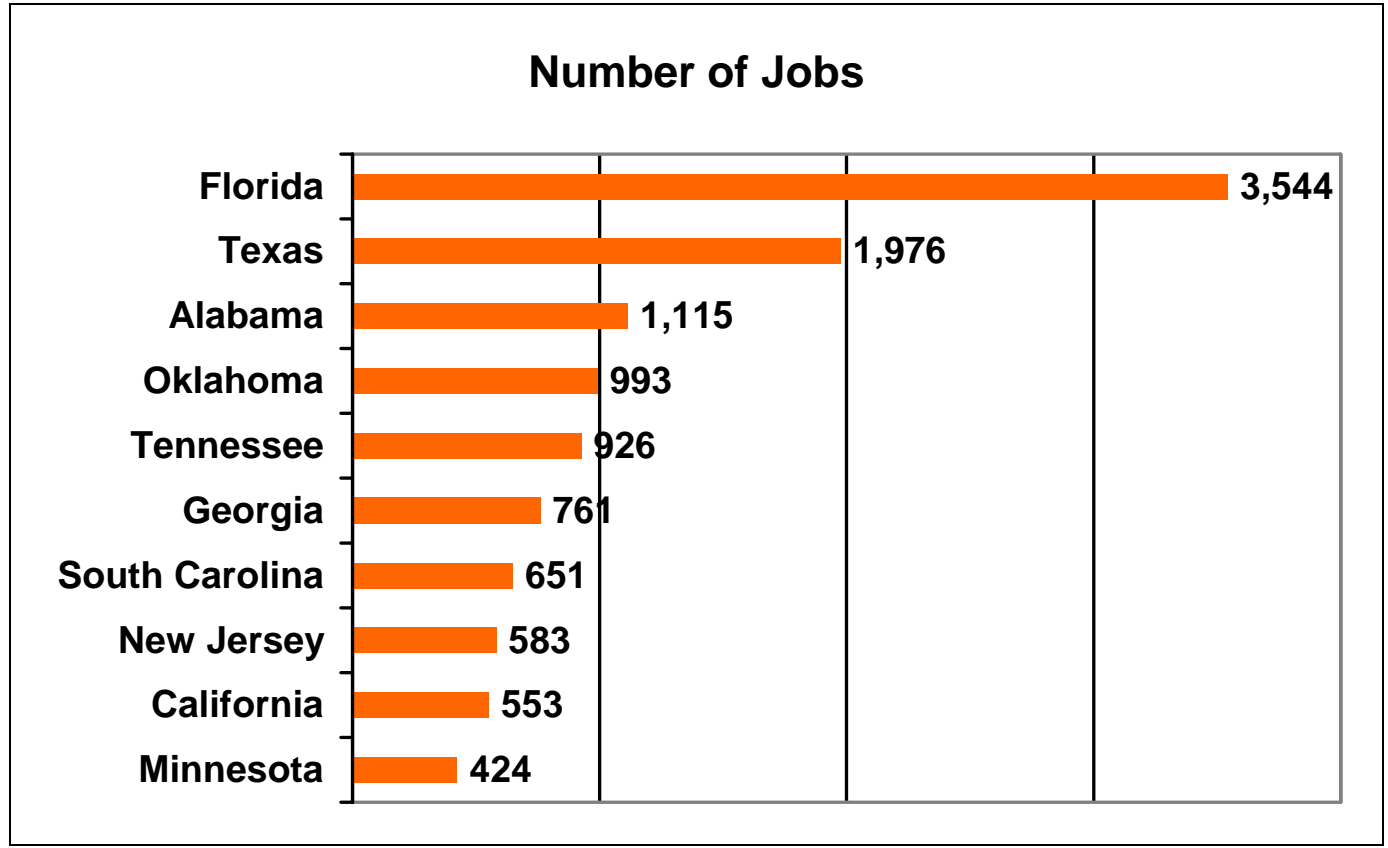

Figure 4. Top ten states for employment impacts of the sod production sector, 2002. 


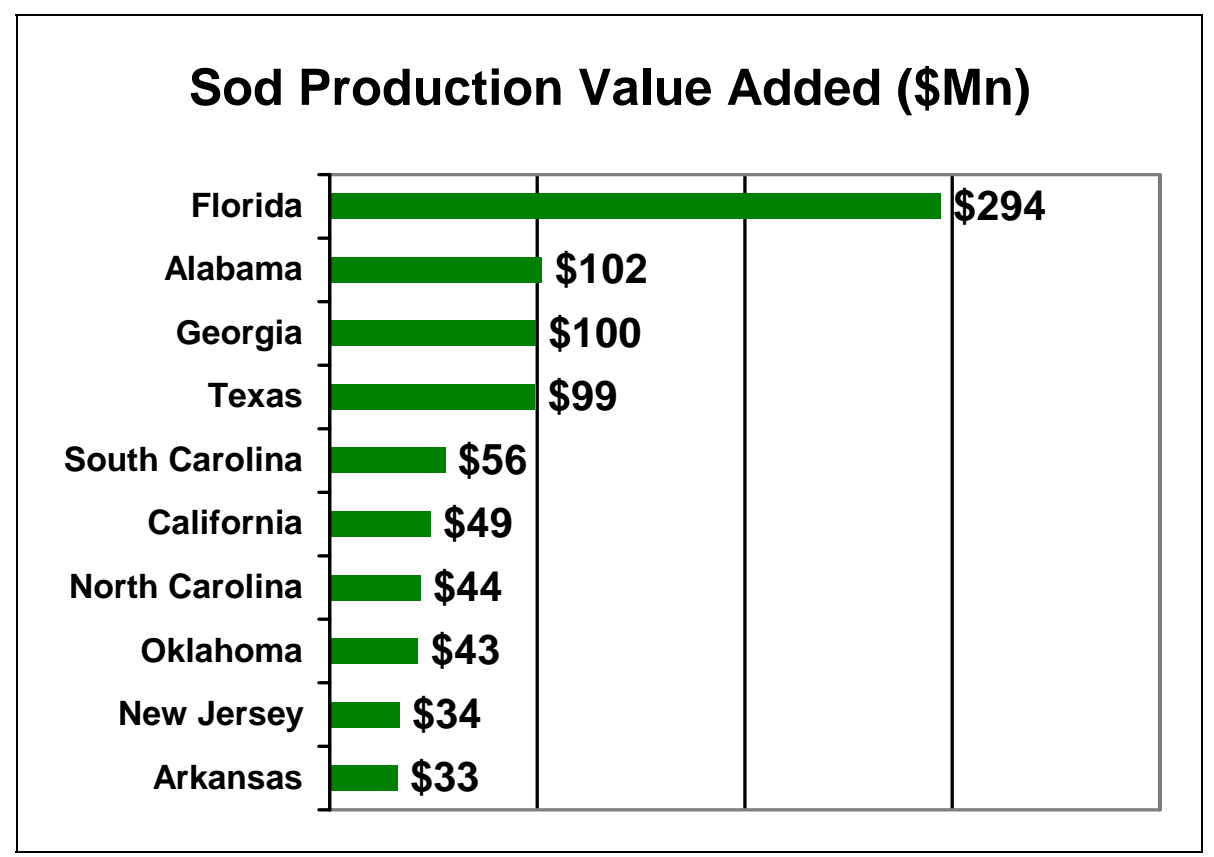

Figure 5. Top ten states for value added impacts of the sod production sector, 2002.

\section{The Lawncare Services Sector}

As defined previously, the lawncare services sector includes firms that provide turfgrass-related horticultural services and are a subset of the firms included in the NAICS sector entitled "Landscaping Services” (561730). This industry sector comprises those establishments primarily engaged in providing landscape care and maintenance services and/or installing trees, shrubs, plants, lawns, or gardens. As a secondary activity, these firms may also design landscapes and/or plans for the construction of walkways, retaining walls, decks, fences, ponds, and similar structures. As a cross-reference, firms in this sector do not include establishments primarily engaged in installing artificial turf or in constructing or installing walkways, retaining walls, decks, fences, ponds, or similar structures, which are classified under Construction (Sector 23); planning and designing the development of land areas for projects, such as parks and other recreational areas; airports, highways, hospitals, schools, land subdivisions, and commercial, industrial, and residential areas, which are classified in, Landscape Architectural Services (541320); retailing landscaping materials and providing the installation and maintenance of these materials, which are classified under Nursery, Garden Center, and Farm Supply Stores (444220).

Sales from these lawncare-related specialty services were $\$ 8.59$ billion, or over one-third (36\%) of a $\$ 35.24$ billion in total U.S. landscape services (Table 7). The top three sectors were lawn care services (SIC: 0782-0203), landscape contractors (SIC: 0782-9903), and lawn services (SIC: 0782-0200) accounting for over 80 percent of all revenues generated by this sector (U.S. Department of Labor, Standard Industrial Classification System).

The total value of lawncare services provided in 2002 totaled \$12.8 Bn. Total economic impacts derived from the lawncare services sector include \$18.5 Bn in output impacts, 295,481 jobs, and \$12.4 Bn in economic value added (Appendix Table B-2). All 50 states reported lawncare services activity with the total number of firms per state ranging from 46 (in Alaska) to 3,643 in California. Thirteen states had over 1,000 service providers, while twelve others reported between 500 and 1000 service providers within their respective states. The top ten states represented a combined 20,559-lawncare service providers who accounted for 54 percent of the industry's total number of establishments. 
Table 7. Value of U.S. turfgrass-related landscape services specialties.

\begin{tabular}{lrrr}
\hline \multicolumn{1}{c}{ Industry Description } & $\begin{array}{c}\text { Number } \\
\text { Businesses }\end{array}$ & $\begin{array}{c}\text { Employment } \\
\text { (jobs) }\end{array}$ & Sales (\$Mn) \\
\hline Lawn services & 9,348 & 36,391 & $1,396.2$ \\
Cemetery upkeep services & 155 & 755 & 28.0 \\
Fertilizing services, lawn & 301 & 1,710 & 115.3 \\
Lawn care services & 24,475 & 66,202 & $2,759.8$ \\
Mowing services, lawn & 2,017 & 4,298 & 149.8 \\
Mulching services, lawn & 112 & 637 & 38.8 \\
Seeding services, lawn & 206 & 1,191 & 79.9 \\
Sodding contractor & 532 & 3,112 & 148.9 \\
Spraying services, lawn & 300 & 2,094 & 75.3 \\
Sprigging services, lawn & 5 & 5 & 0.1 \\
Turf installation services, except artificial & 518 & 1,295 & 53.6 \\
Bermuda sprigging services & 32 & 150 & 6.5 \\
Highway lawn and garden maintenance services & 380 & 2,720 & 185.1 \\
Lawn and garden services & 6,034 & 19,834 & 750.1 \\
Garden services & 614 & 1,284 & 43.8 \\
Garden maintenance services & 187 & 1,372 & 52.6 \\
Garden planting services & 35 & 136 & 5.5 \\
Landscape contractors & 8,588 & 53,080 & $2,698.0$ \\
\hline Total & 53,840 & 196,266 & $8,587.2$ \\
\hline Source: Dun
\end{tabular}

Source: Dun \& Bradstreet Information Services, 1997.

Figure 6 illustrates the top 10 states in terms of the total output impacts associated with lawncare service. These top 10 states represented \$10.2 Bn in total output impacts, approximately 55 percent of the U.S. total. The top 3 states were California, Florida, and Texas with \$2.9 Bn, \$1.3 Bn, and \$1.1 Bn in total output impacts, respectively, together representing 28 percent of the national total. Interestingly, Virginia and Maryland, though not in the top 10 in terms of the number of lawncare service providers in their states, were in the top 10 in terms of output impacts generated, displacing New York and Michigan, which had more establishments but lower output impacts.

In terms of total employment impacts, the lawncare services sector represented a total of 295,841 jobs, with the top 10 states representing 168,382 (57\%) of the total number of jobs, as depicted in Figure 7 . This time, Virginia and Georgia entered the top 10 in terms of total employment impacts in spite of the fact that each had fewer numbers of firms located in their respective states than the states they displaced (New York and Michigan). As before, the top three states were California, Florida, and Texas - more than doubling the number of jobs provided by the other top 10 states.

Total value added impacts of the top 10 states (Figure 8) amounted to $\$ 6.9 \mathrm{Bn}$, which was about 50 percent of the national total of $\$ 12.4 \mathrm{Bn}$. These results seem to indicate that the lawncare services sector represents substantial labor income impacts particularly in the top 10 states. 


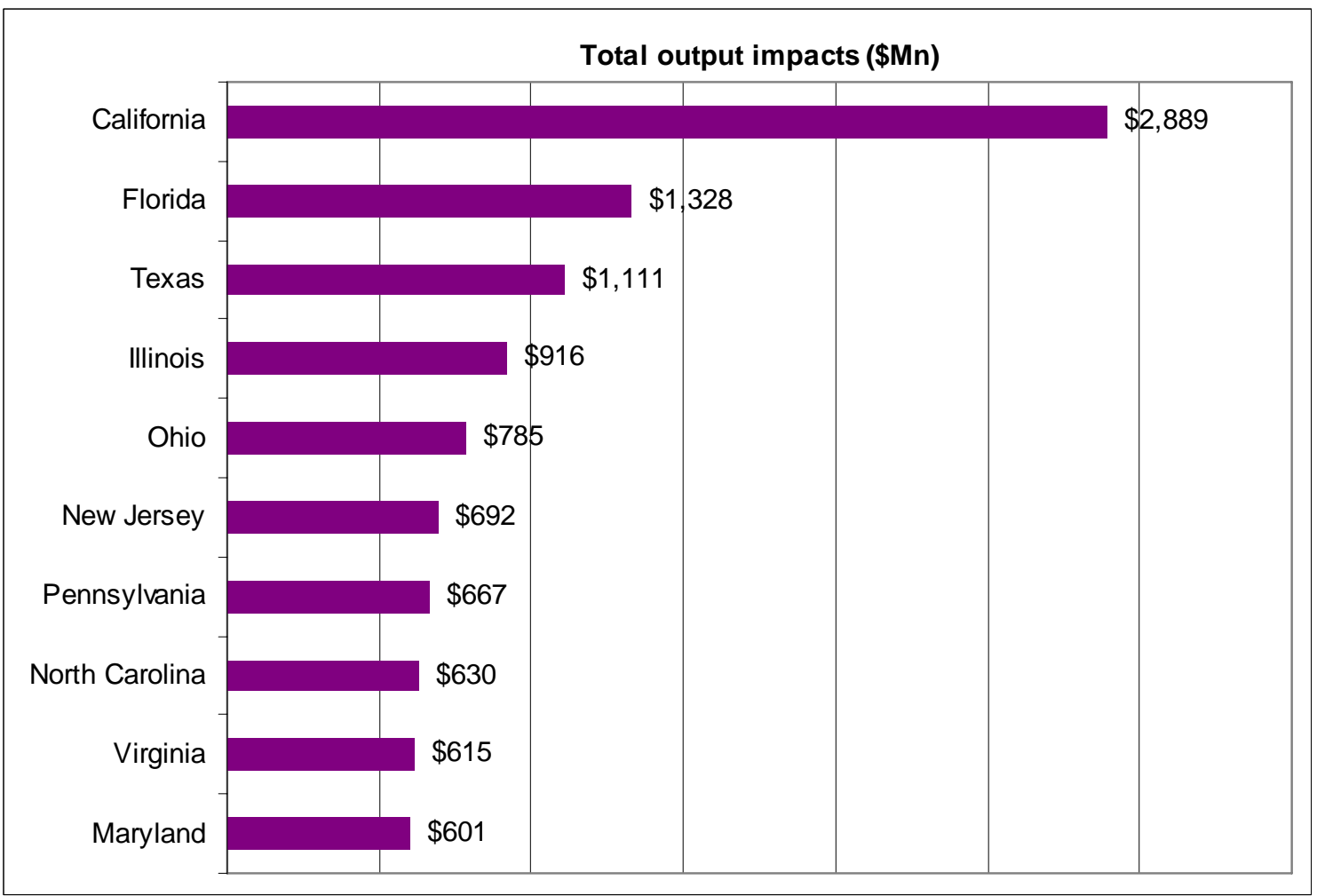

Figure 6. Top ten states for output impacts of the lawncare services sector, 2002.

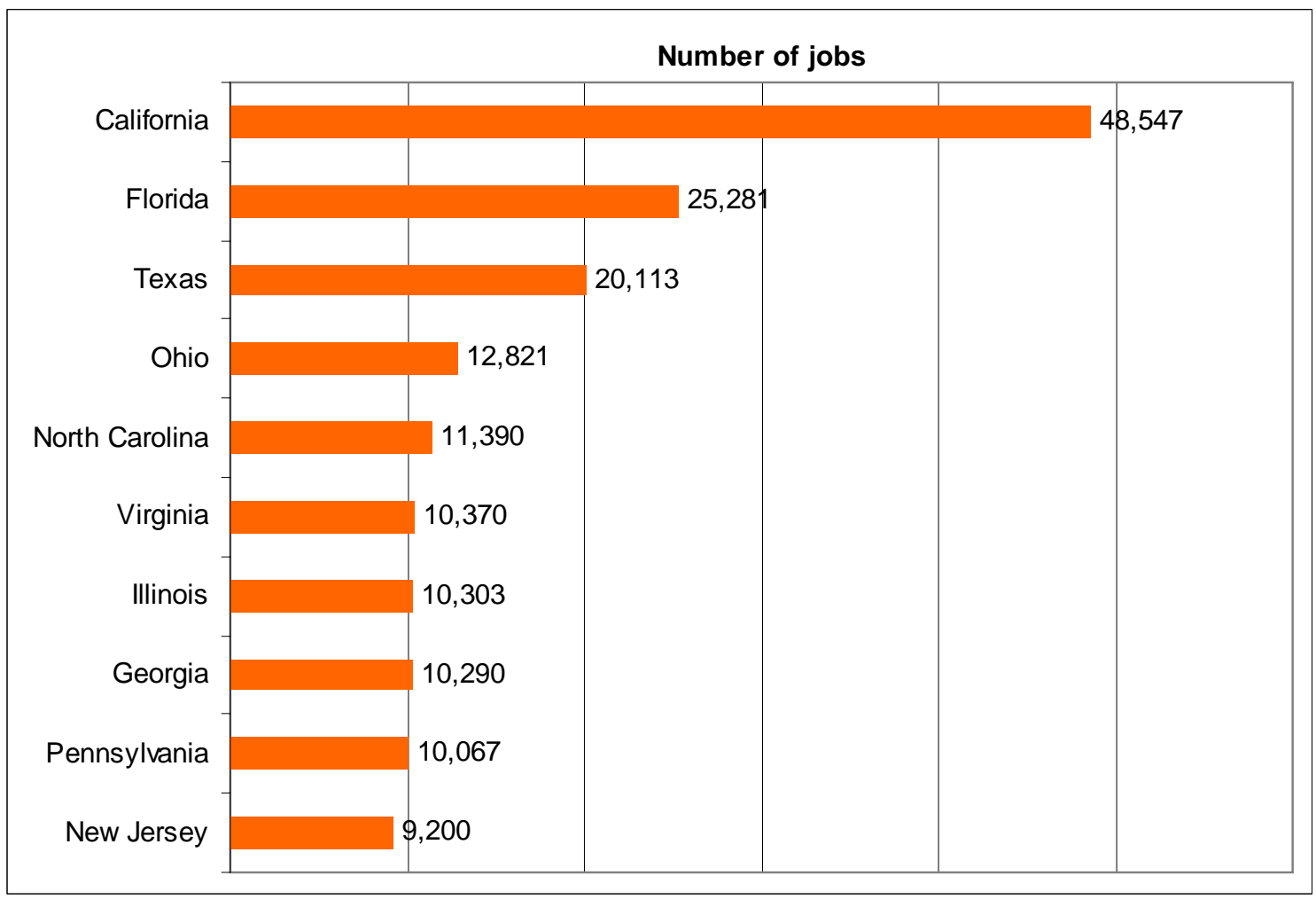

Figure 7. Top ten states for employment impacts of the lawncare services sector, 2002. 


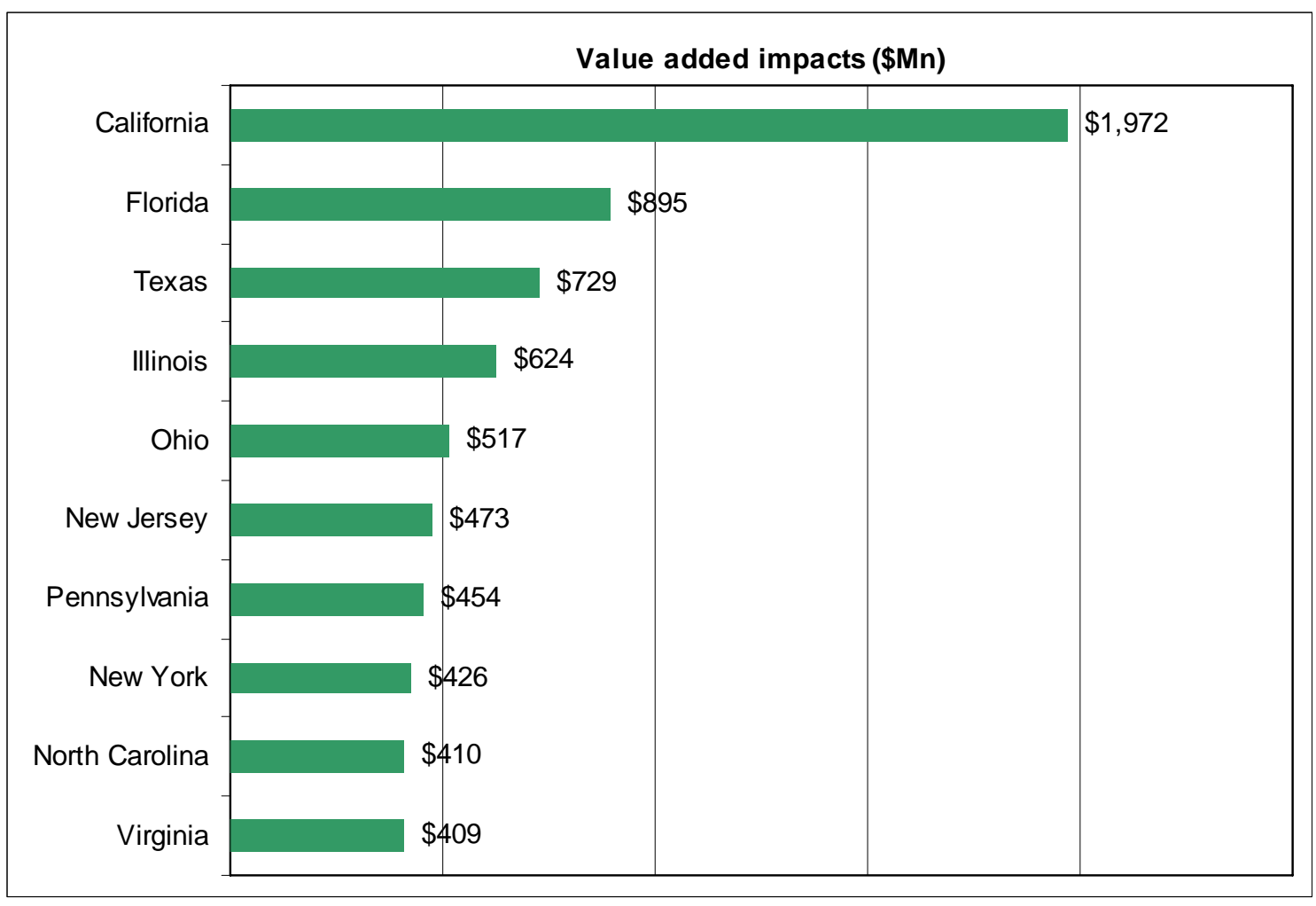

Figure 8. Top ten states for value added impacts of the lawncare services sector, 2002.

\section{The Lawncare Goods Retailing Sector}

As defined previously, the lawncare goods retailing sector includes firms that provide turfgrass-related goods and are a subset of the firms included in the NAICS sector entitled "Lawn and Garden Equipment and Supplies Stores" (4442) and "Home Centers" (44411). By definition, retail lawn and garden supply stores are independent and chain stores that sell primarily horticultural goods and services to end consumers. Retail building materials and supply stores are largely home improvement centers, such as Lowes, Home Depot, and Ace Hardware, all of which have lawn and garden centers and sell an assortment of turfgrass and turfgrass maintenance-related products.

The total value of turfgrass-related lawncare goods retailing in 2002 totaled \$3.5 Bn. Appendix Table B-3 summarizes total economic impacts derived from the lawncare goods retailing sector including $\$ 8.5 \mathrm{Bn}$ in output impacts, 114,294 jobs, and \$5.5 Bn in economic value added. As stated earlier, the calculation for retail sectors assumed output is reduced to reflect only the gross margin on sales (29.5 percent) according to national averages of for lawn and garden stores and building materials and supply stores (U.S. Census Bureau, 2004b; 2004d). All 50 states reported lawncare goods retailing activity.

Figure 9 illustrates the top 10 states in terms of the total output impacts associated with lawncare goods retailing. These top 10 states represented $\$ 3.7 \mathrm{Bn}$ in total output impacts, approximately 47 percent of the U.S. total. The top 3 states included California, Texas, and Illinois with \$798 Mn, \$645 Mn, and \$417 Mn in total output impacts, respectively, representing 22 percent of the national total output. The next leading states in the top 10 (in terms of output impacts) included Pennsylvania, Ohio, Florida, New York, Missouri, Virginia and Wisconsin (in descending order).

In terms of total employment impacts, the lawncare goods retailing sector represented a total of 114,294 jobs, with the top 10 employing states representing 51,428 (45\%) of the total (Figure 10). The same top 10 output impact states indicated above were also the top 10 employing states, although Missouri, Wisconsin, Virginia and New York changed with respect to the order they appeared in the top 10 employing states.

Total value added impacts of the top 10 states (Figure 11) amounted to $\$ 2.6 \mathrm{Bn}$, which was about 47 percent of the national total of $\$ 5.5 \mathrm{Bn}$. Georgia replaced Wisconsin in the top 10 states in terms of value added 
impacts, with Wisconsin dropping to the $11^{\text {th }}$ place spot. These results indicate that the lawncare goods retailing sector generates substantial labor income impacts and indirect business taxes, due to the high level of labor inputs in the retail sector.

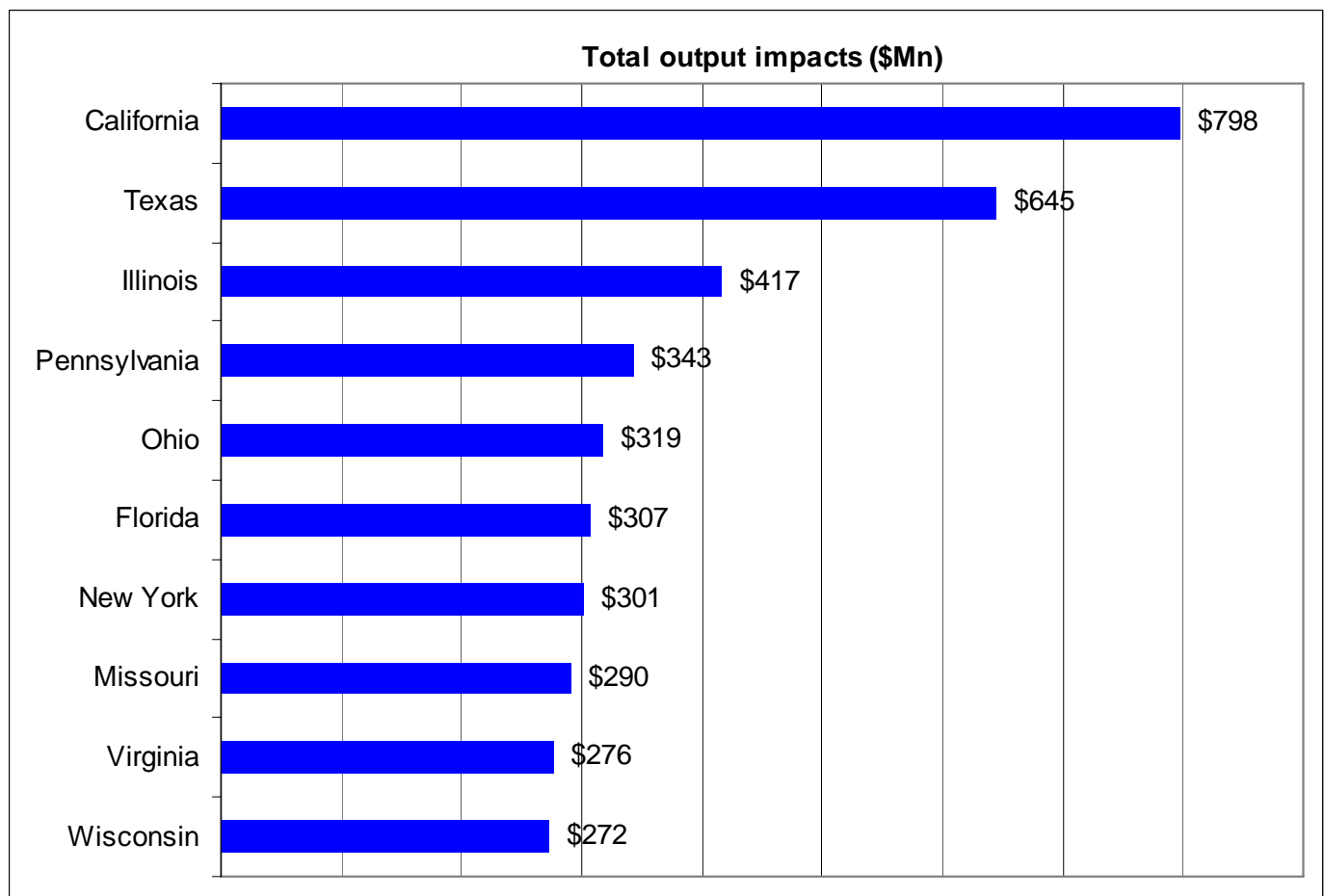

Figure 9. Top ten states for output impacts of the lawncare goods retailing sector, 2002.

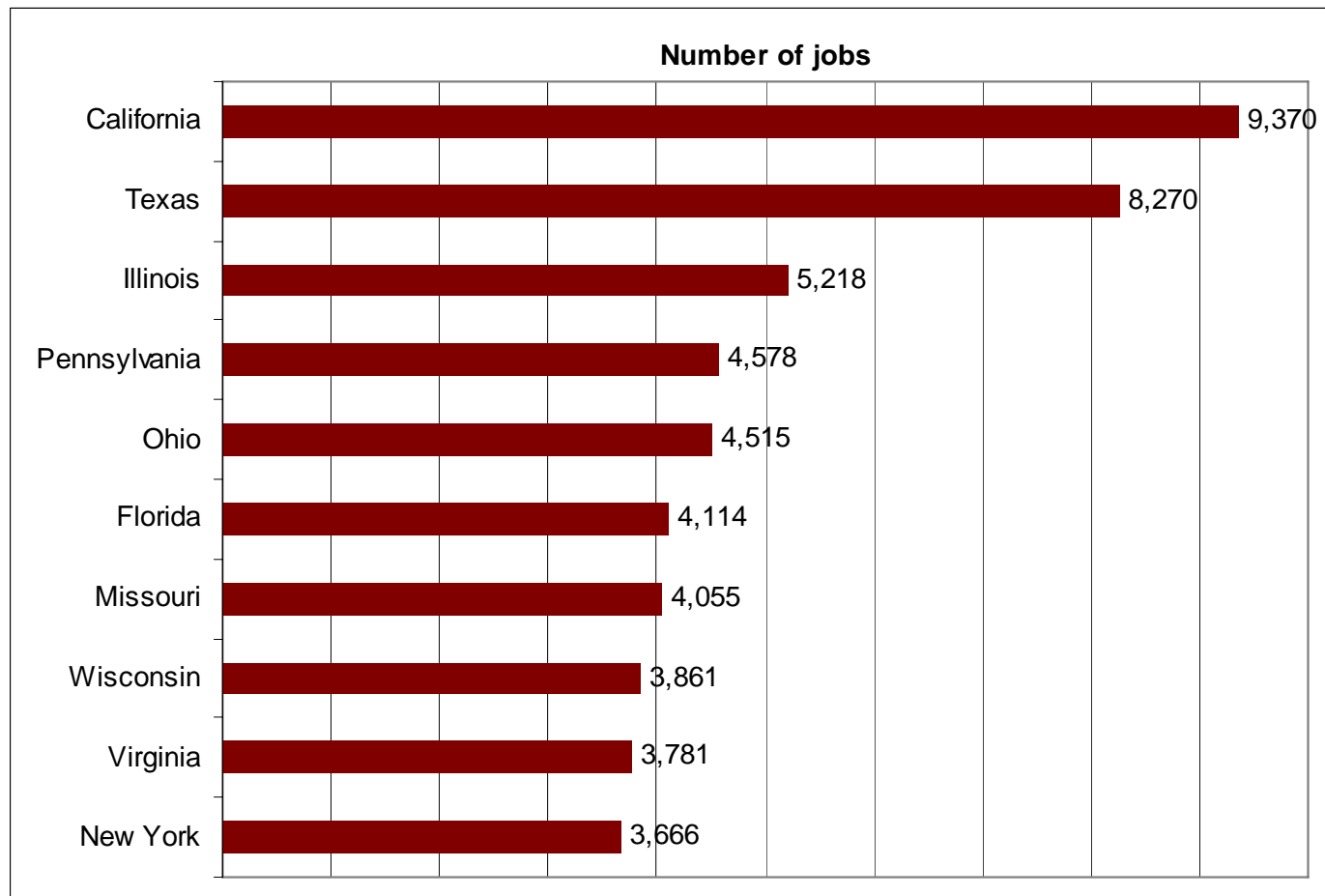

Figure 10. Top ten states for employment impacts of the lawncare goods retailing sector, 2002. 


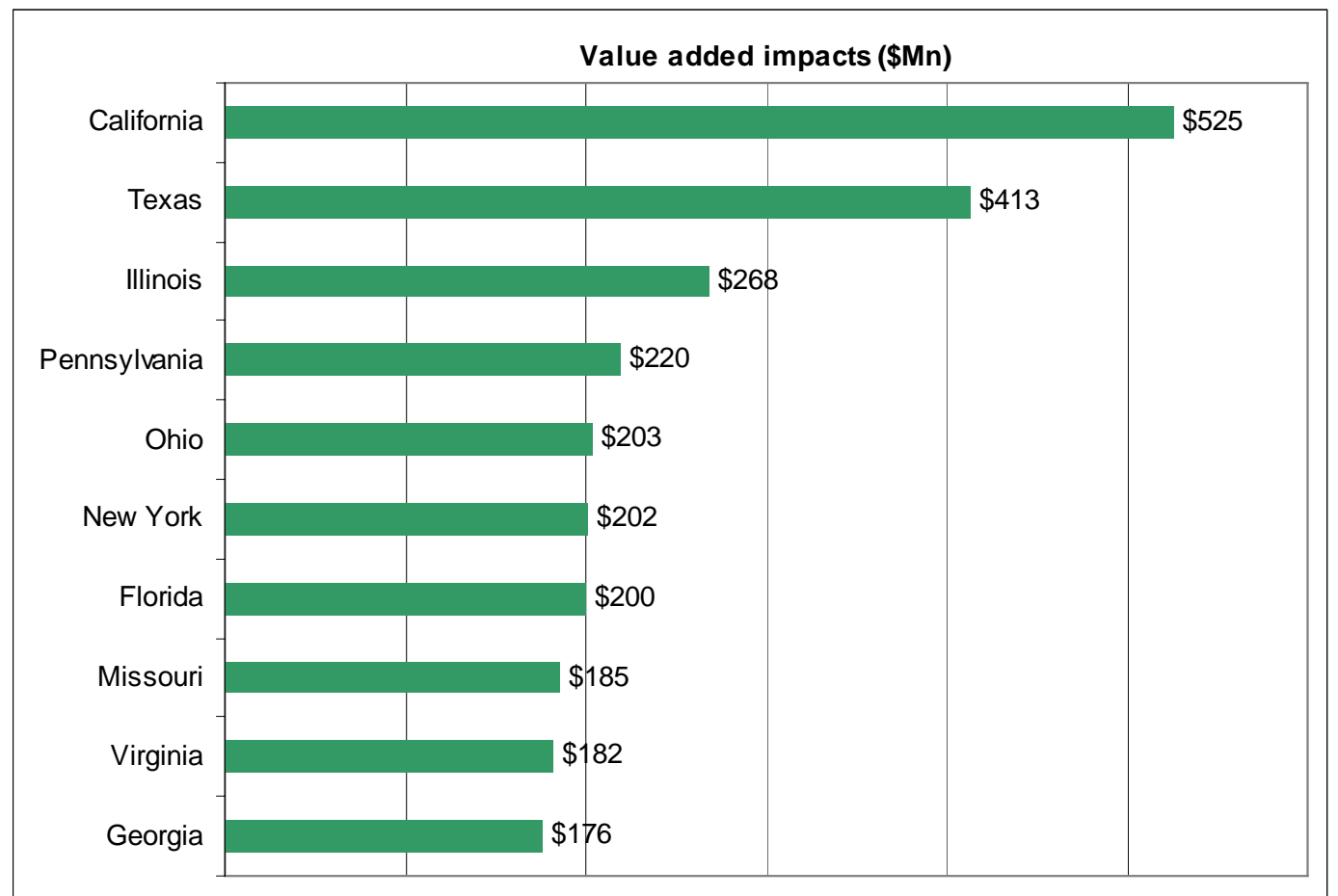

Figure 11. Top ten states for value added impacts of the lawncare goods retailing sector, 2002.

\section{The Lawn Equipment Manufacturing Sector}

As defined previously, the lawn equipment sector includes firms that manufacture commercial turf and grounds care equipment (including parts and attachments), push-type lawnmowers, powered lawn edgers/trimmers, yard vacuums and blowers, lawn tractors and riding mowers, and parts and attachments for consumer lawn and garden equipment. The total value of shipments of lawn equipment in 2002 totaled \$6.1 Bn (Table 8). Appendix Table B-4 summarizes total economic impacts derived from the lawn equipment sector including \$7.5 Bn in output impacts, 33,995 jobs, and \$2.4 Bn in value added. Thirty-seven of the 50 states reported lawn equipment manufacturing activity with the total number of firms per state ranging from one (in 9 states) to twelve in Indiana. Four states had only 2 manufacturing locations, while nine others reported 3 manufacturing locations within their respective states. The top ten states represented a combined 81 manufacturing locations, which accounted for 54 percent of the industry's manufacturing sites. Lawn equipment was segregated into six different categories, accounting for a total of $\$ 6.15$ billion in sales in 2003. Of the six categories, the top two in terms of sales were lawn tractors and riding mowers for homeowners ( $\$ 2.2 \mathrm{Bn})$ and commercial turf and grounds care equipment at \$1.7 Bn.

Table 8. Value of U.S. lawn equipment manufacturing shipments, 2002.

\begin{tabular}{lr}
\hline \multicolumn{1}{c}{ Type Equipment } & $\begin{array}{c}\text { Value of } \\
\text { Shipments } \\
\text { (Mn\$) }\end{array}$ \\
\hline Commercial turf \& grounds care equipment, incl. parts \& attachments & $1,677.9$ \\
Push-type lawnmowers (consumer) & 961.8 \\
Powered lawn edgers/trimmers (consumer) & 514.0 \\
Yard vacuums \& blowers (consumer) & 222.3 \\
Lawn tractors \& riding mowers (consumer) & $2,224.6$ \\
Parts and attachments for consumer lawn \& garden equipment & 547.9 \\
Total & $6,148.4$ \\
\hline
\end{tabular}

Source: U.S. Census Bureau, 2003a. 
Figure 12 illustrates the top 10 states in terms of the total output impacts associated with lawn equipment manufacturing. These top 10 states represented $\$ 6.0 \mathrm{Bn}$ in total output impacts, approximately 80 percent of the U.S. total. Interestingly, South Carolina, Arkansas, and Mississippi all entered the top 10 in terms of total output impacts in spite of indicating that they each had only 3 manufacturing firms located in their respective states. They displaced California, Michigan, and Pennsylvania in the top 10 even though these states had considerably higher numbers of firms represented $(8,6$, and 10 , respectively), reflecting the size and scale of their manufacturing sites. The top 3 states included Wisconsin, Tennessee, and South Carolina with \$1.15 $\mathrm{Bn}, \$ 1.09 \mathrm{Bn}$, and \$1.08 Bn in total output impacts, respectively. The next closest state in terms of output impacts (Georgia) represented less than half of any of the top three states.

In terms of total employment impacts, the lawn equipment sector represented a total of 33,995 jobs, with the top 10 states representing 27,956 (82\%) of the total number (Figure 13). Again, South Carolina, Arkansas, and Mississippi all entered the top 10 in terms of total employment impacts in spite of indicating that they each had only 3 manufacturing firms located in their respective states. They again displaced California, Michigan, and Pennsylvania, again reflecting perhaps the greater employment associated with the size and scale of their manufacturing sites. More than doubling the number of jobs of any of the other top 10 states, the top three states included Wisconsin, Tennessee, and South Carolina.

Total value added impacts of the top 10 states (Figure 14) amounted to $\$ 1.9 \mathrm{Bn}$, which was about 80 percent of the national total of $\$ 2.4 \mathrm{Bn}$. These results seem to indicate that the manufacturing of lawn equipment is highly concentrated geographically and represents substantial labor income impacts and indirect business taxes, particularly in the top 10 states.

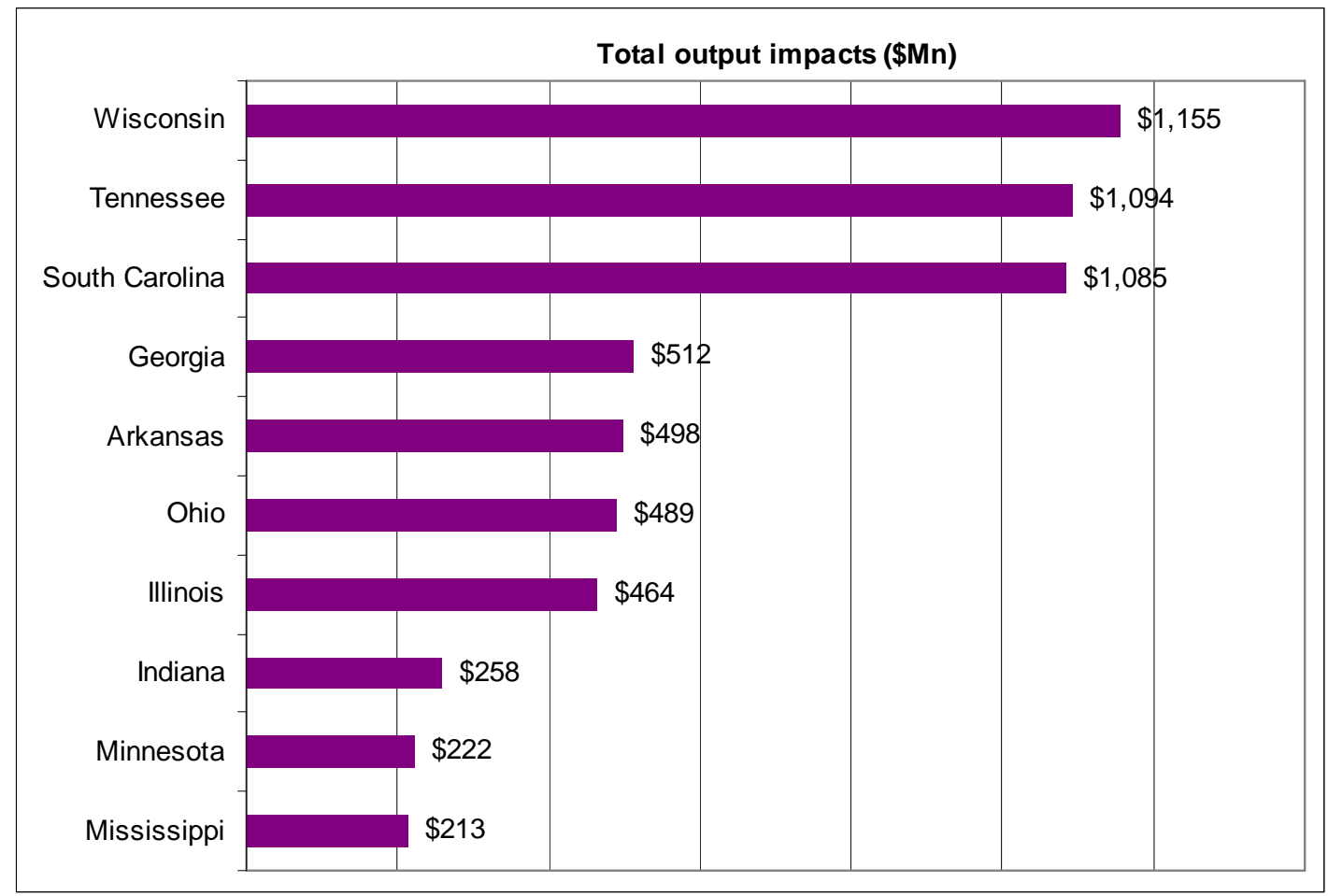

Figure 13. Top ten states for output impacts of the lawn equipment sector, 2002. 


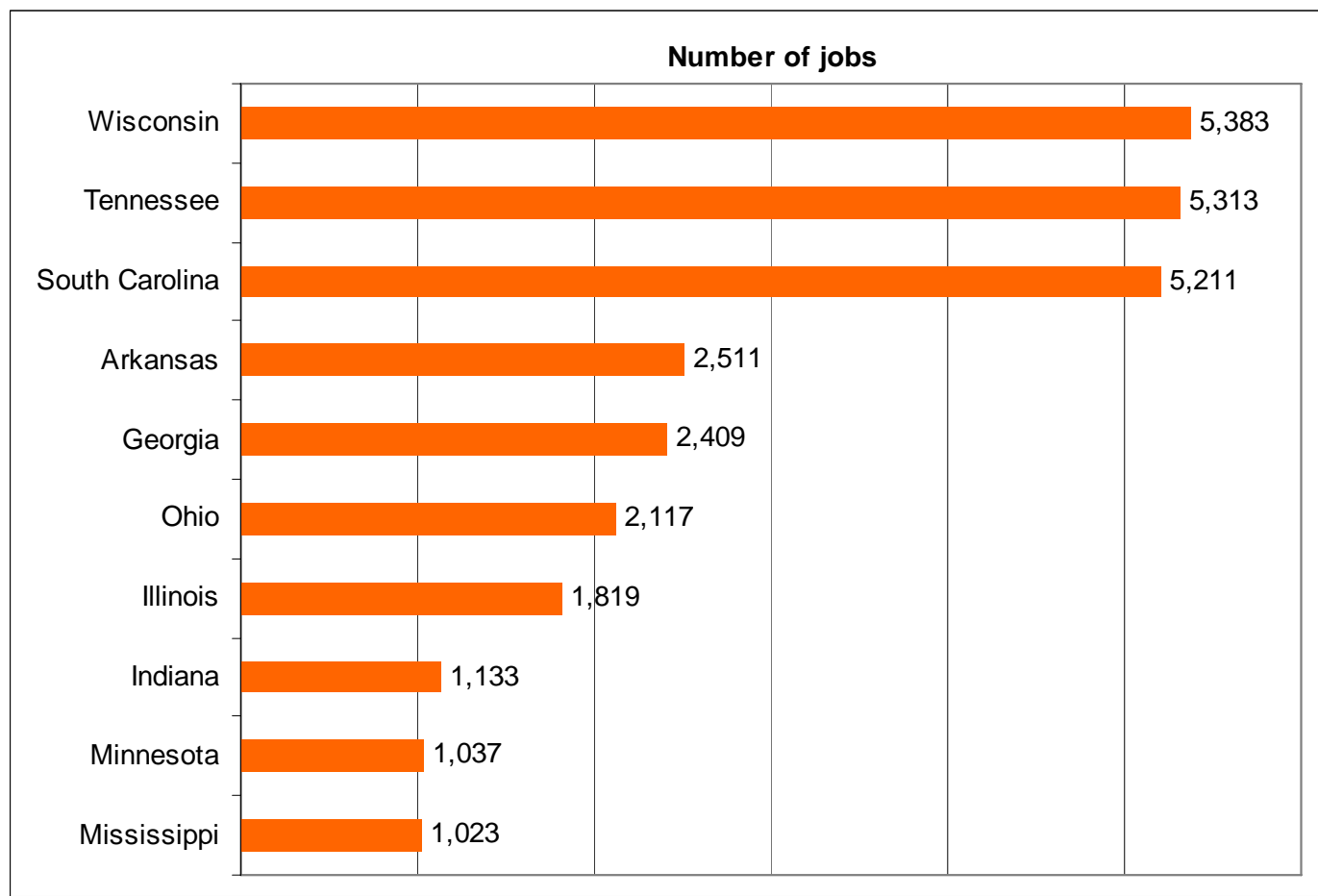

Figure 13. Top ten states for employment impacts of the lawn equipment sector, 2002.

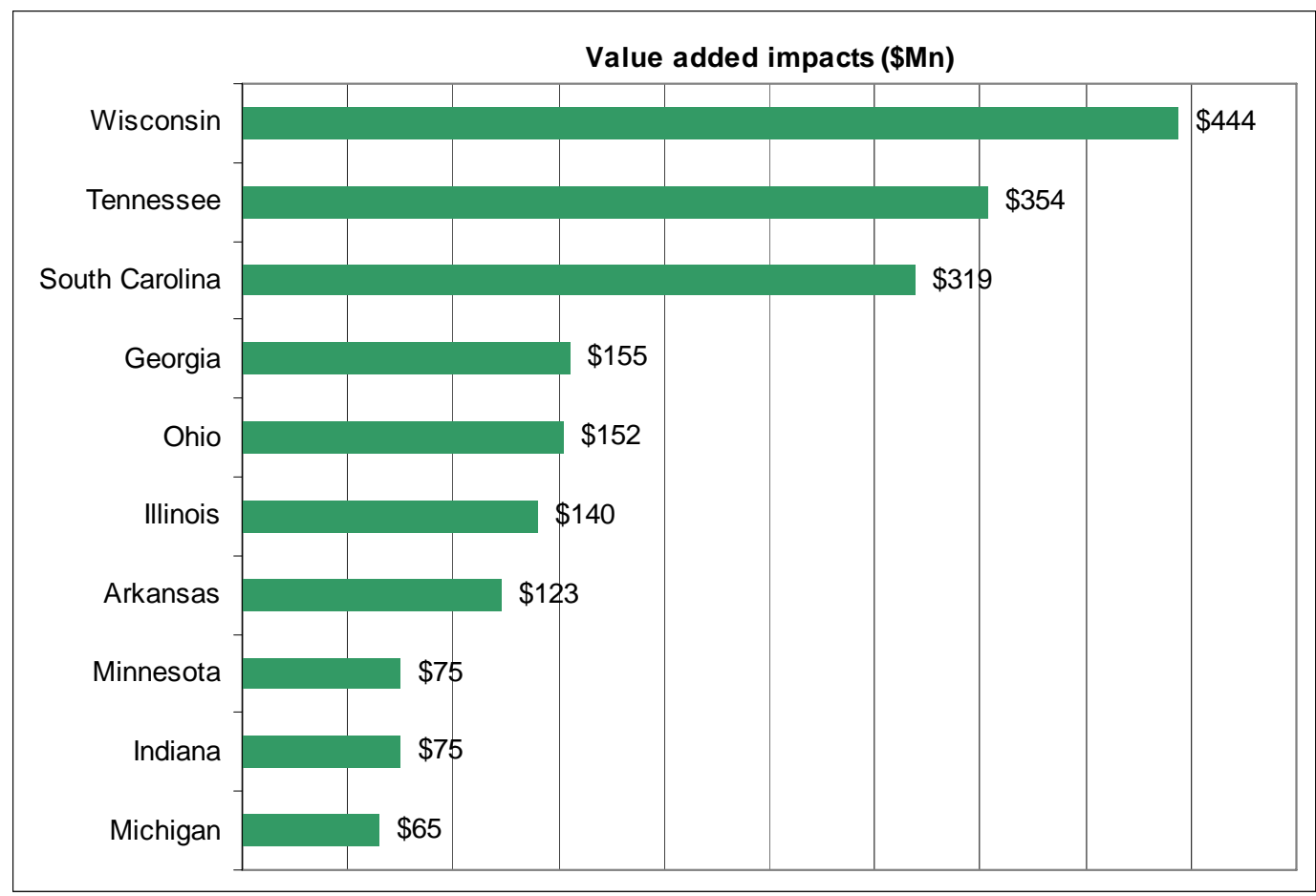

Figure 14. Top ten states for value added impacts of the lawn equipment sector, 2002. 


\section{The Golf Course Sector}

Golf is a highly popular recreational activity in the United States. According to the National Golf Foundation, in 2004 there were over 16,000 golf facilities nationwide (NGF, 2005). A facility is defined as a complex that contains at least one golf course. Golf courses typically fall into eight categories, but are dominated by three major types - private, semi-private and public. Increasingly, residential developments are incorporating golf courses as part of their recreational facilities. In fact, about 60 percent of golf courses currently under construction will be part of a residential community, but only 22 percent of existing courses are part of a golf community. The five states with the most golf courses are: 1) Florida - 1,073; 2) California 925; 3) Texas - 857; 4) Michigan - 852; and 5) New York - 822. This state ranking, including the total number of courses in the U.S., differs considerably from the Economic Census data used in the study (Appendix Table B-5). The government census data lists a total of 11,836 golf courses in the country, a difference of roughly 5,000 units (26\%) compared to NGF data. This discrepancy is a result of two factors. First, the census data is for 2002, as opposed to the more recent (2004) NGF data. The second and most significant reason is due to the definition of a golf course establishment used by the U.S. Census Bureau. According to the definition given in the report, an establishment is typically a "single physical location". Related to this, when establishments had multiple economic activities, the one with the most dominant activity was selected. In this case, a golf course residing in an upscale residential community may not be recognized as a golf course, because it represents a lesser economic activity than the overall development. Therefore, the low number of golf courses reported is due to their classification under other industry sectors, such as residential developers, non-profit community associations, or municipal governments. As a consequence, the results presented below will be understated for golf courses. This underestimate is in the neighborhood of 25 percent nationally, but varies considerably more across independent states. For instance, NGF shows Florida with 1,073 facilities in 2004, but the Census data lists 587, a discrepancy of about 80 percent; California, on the other hand, has a difference of only 34 percent.

Of the five turfgrass sectors examined in this study, golf courses were the single largest component (37 percent) in terms of economic impact for 2002. In that year, the 11,836 U.S. golf facilities generated \$21.8 Bn in output impacts, employed 361,690 people, and contributed $\$ 13.5 \mathrm{Bn}$ in value added. This sector also provided \$7.9 Bn in labor income and paid \$1.1 Bn in indirect business taxes. Due primarily to this significance, it should be noted that, although turfgrass is a key input to golf operations, it is not the only one, even though in this study we are claiming all the economic impacts of golf courses. For instance, restaurants and lodging establishments rely on turfgrass only indirectly; yet contribute significantly to total impacts.

All 50 states were listed as having golf course establishments. The average number of establishments per state was 237, the fewest number (18) was located in Alaska and the most (689) situated in California. A listing of the top 10 states for the number of golf course firms, according to Census Bureau's estimates, are shown in Appendix Table B-5. As noted, California is ranked number one with the most golf courses (689), followed by New York (674), Michigan (652), Ohio (646), Pennsylvania (612), Florida (587), Texas (581), Illinois (497), North Carolina (456) and Wisconsin (393). Combined, the top 10 states comprised nearly half (49\%) of all golf course establishments in the country. Total golf course output impacts for the top 10 states are illustrated in Figure 15. Florida contributed the largest economic impact with $\$ 3.1 \mathrm{Bn}$, followed closely by California with $\$ 2.5 \mathrm{Bn}$. The remaining eight states had output impacts ranging from New York (\$1.0 Bn) to South Carolina ( $\$ 565 \mathrm{Mn}$ ). Combined, the top 10 states contributed over half (57 percent) of golf course output impacts in the U.S. in 2002.

Golf course employment figures for the top 10 states are shown in Figure 16. State-level employment rankings differ somewhat from the output impact rankings discussed above. Florida and California are still number one and two, at 50,938 and 41,858 jobs, respectively. Texas, however has supplanted New York for third place, which is now number eight. Michigan, which was number six, is no longer in the top 10 and has been replaced by Arizona. Two reasons might explain the change in rankings across states when examining employment numbers. First, golf courses in some states may have invested more heavily in capital to offset the increasing cost of labor. For example, golf courses with more automated irrigation systems and technologically advanced maintenance equipment would conceivably reduce labor needs. Second, some establishments may provide a larger array of member services, such as restaurants and bars, clubhouses, and lodging places that would require additional labor resources. Combined, the top 10 states contributed over half (57 percent) of total golf course employment in the U.S. in 2002.

Estimates of the top 10 states for golf course value added are shown in Figure 17. State-level rankings for value added are exactly the same as for output impacts. The top two states in value added were Florida and 
California with \$1.9 Bn and \$1.5 Bn, respectively. The remaining eight states ranged from a high of \$653 Mn for New York to a low of \$349 Mn for South Carolina. Altogether in 2002 the top 10 states provided 54 percent of golf course value added in the U.S.

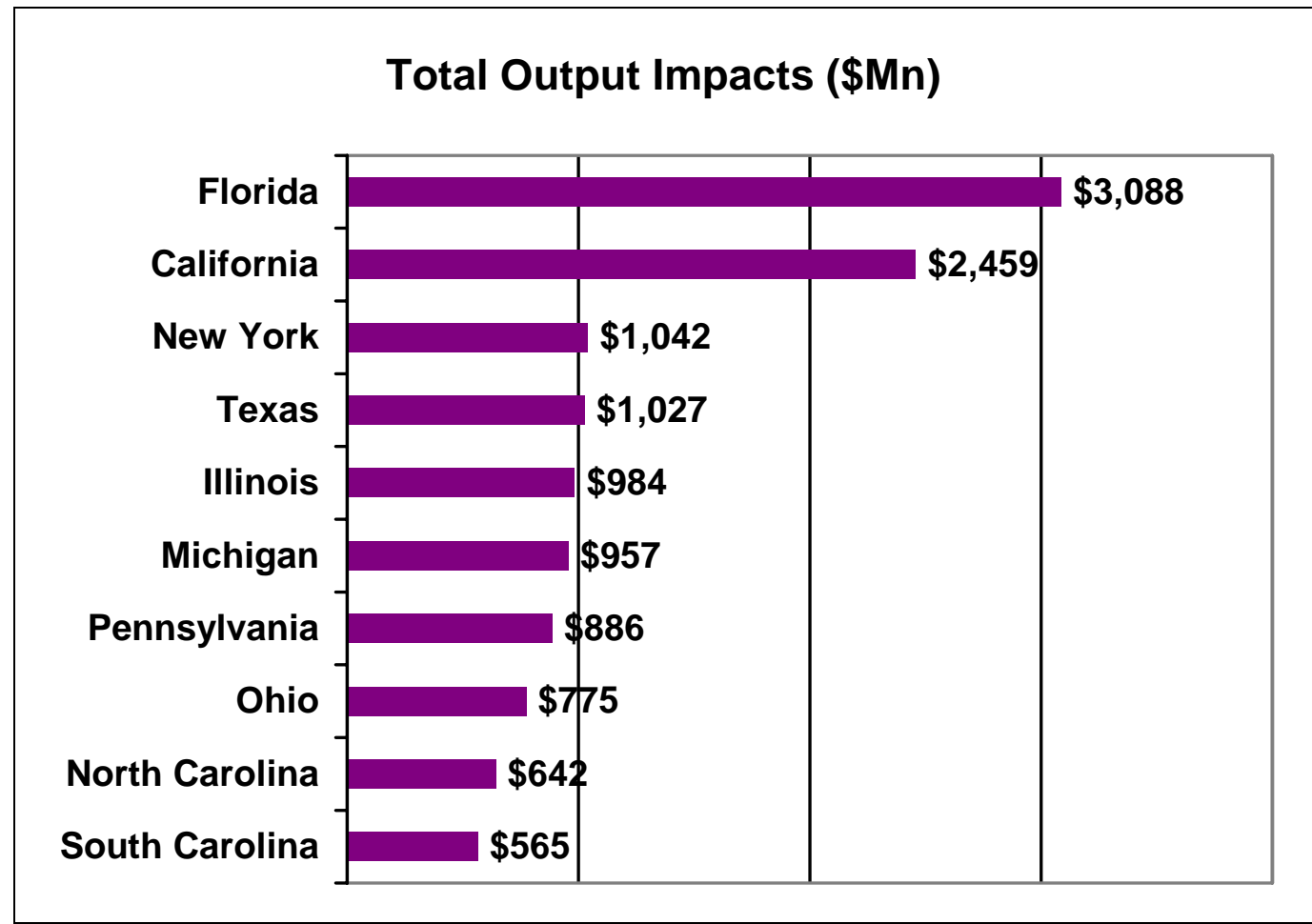

Figure 15. Top ten states for output impacts of the golf course sector, 2002.

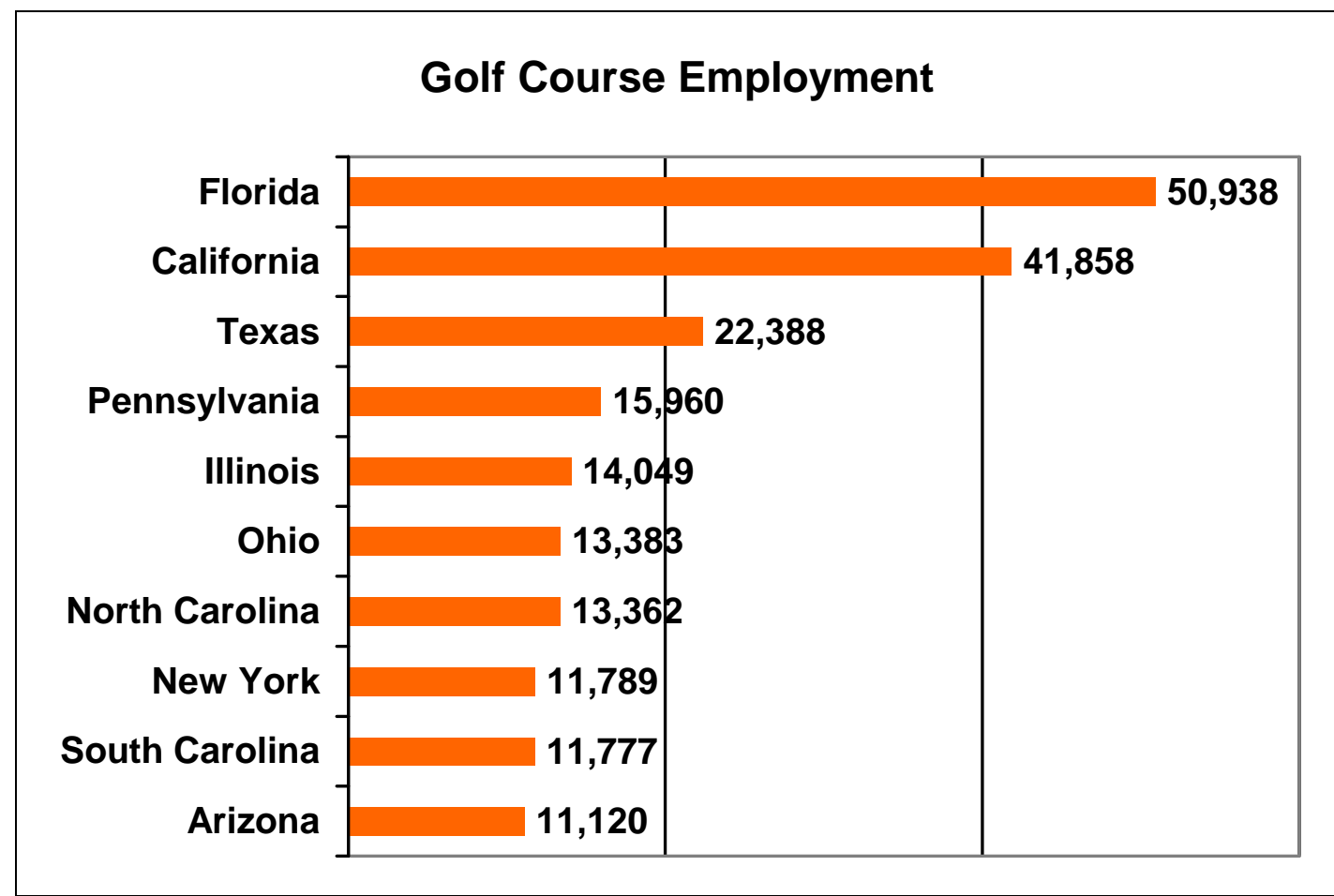

Figure 16. Top ten states for total employment impacts (jobs) of the golf course sector, 2002. 


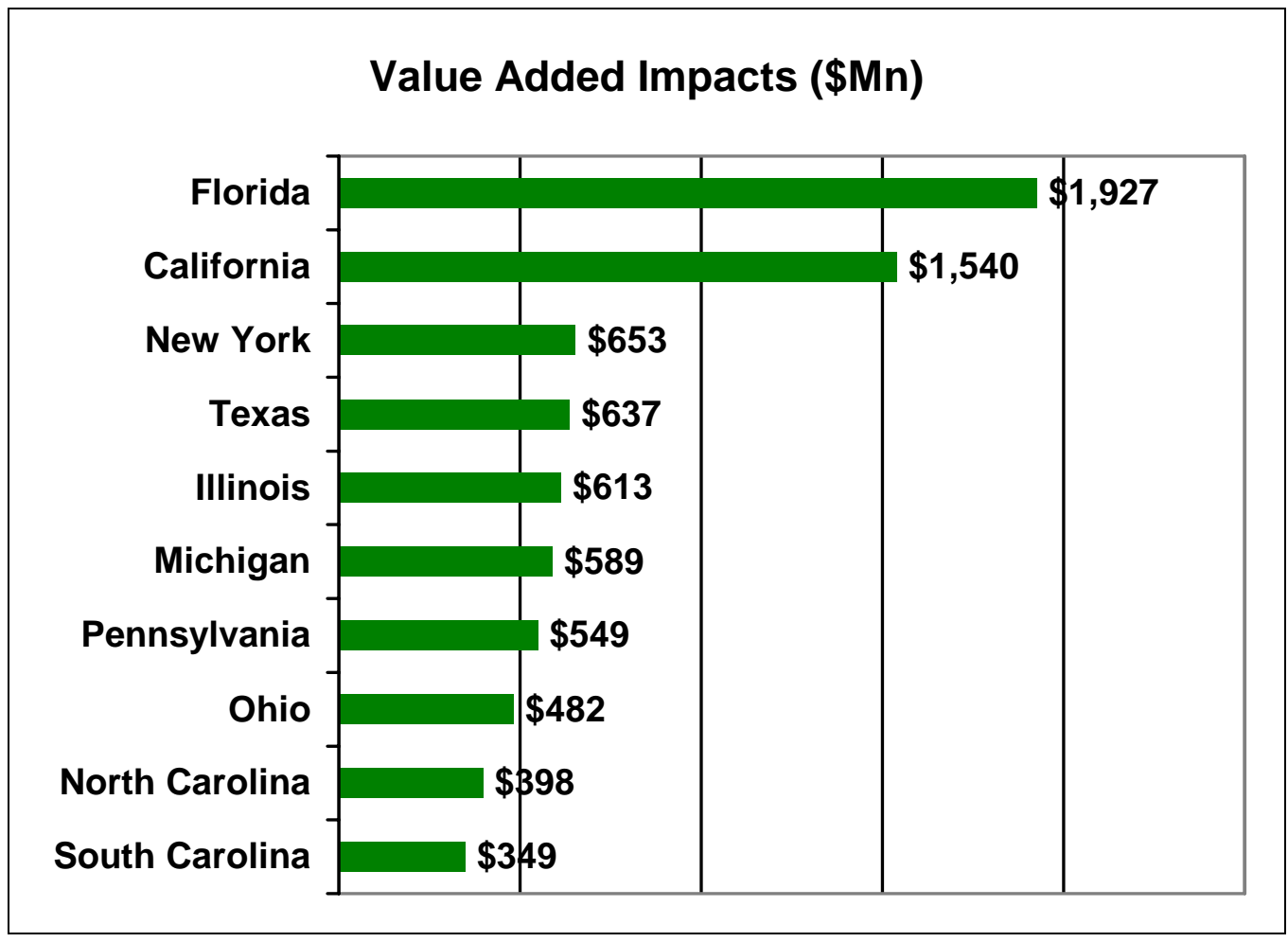

Figure 17. Top ten states for value added impacts of the golf course sector, 2002. 


\section{CONCLUSIONS}

In this study, five sectors were examined to assess contributions of the turfgrass industry to the United States economy. These sectors included sod farms, lawncare services, lawncare retail stores, lawn equipment manufacturing, and golf courses. Missing from the study were several recreational sports groups that were not included due to an absence of secondary data. If data had existed for these other turf-based recreational activities, the estimated economic impact would have been even larger. Still, results from the five groups clearly indicate a large contribution to the national economy. Collectively, in 2005 dollars, these five sectors generated \$62.2 Bn of total output impacts, \$37.7 Bn in value added, remunerated \$24.7 Bn in labor income, paid \$2.6 Bn in indirect business taxes, and generated 822,849 jobs.

At the state level, economic impacts varied markedly by geographic location and type of impact being measured. For the sod production sector, southern states tended to dominate total output impacts due the warmer year-around climate and the higher proportion of sod grown vegetatively. For lawn care services, there was no discernable pattern across states. California was the single largest contributor, followed by Florida and Texas. Interestingly, central (Illinois, Ohio) and several northern states (New Jersey, Pennsylvania, Virginia and Maryland) were also in the top ten tier. For the lawn equipment sector, Wisconsin, Tennessee and South Carolina were the top three states, each with over a billion dollars in total output impacts. For the lawn care goods retailing sector, California and Texas stood out, followed by a mixture of southern, central and northern states. In the case of golf courses, Florida and California clearly dominated with \$3.1 Bn and \$2.5 Bn in output impacts, respectively, with New York, Texas, Illinois and Michigan comprising a secondary tier with roughly \$1 Bn each. 


\section{LITERATURE AND INFORMATION SOURCES CITED}

Behe, B., J. Hardy, S. Barton, J. Brooker, T. Fernandez, C. Hall, J. Hicks, R. Hinson, P. Knight, R. McNiel, T. Page, B. Rowe, C. Safley, and R. Schutzki. 2005. Landscape Plant Material, Size, and Design Sophistication Increase Perceived Home Value. Journal of Environmental Horticulture (accepted).

Brooker, John C., C. Hall, D. Eastwood, J. Haydu, and A. Hodges. 2005. The Fourth National Industry Survey of Production and Marketing Practices. Southern Nursery Association 49:38-43.

Butterfield, B. 2005. National Gardening Survey, 2004. National Gardening Association, Burlington, VT.

Campbell, Ramsey, and Robert Sargent. 2001. Water Crisis May Strike Here by 2006. The Orlando Sentinel, November 27, p.A1.

Carriker, R.L. 1993. Agriculture, Water Quality, and Public Policy. Food and Resource Economics Department Staff Paper SP-96-15, University of Florida, Gainesville, FL.

Des Rosiers, F., M. Theriault, Y. Kestens, and P. Vleeeneuve. 2002. Landscaping and House Values: An Empirical Investigation. Journal of Real Estate Research 23(1-2):139-161.

Dun and Bradstreet Information Systems. 1997. Industry reports, available at http://www.zapdata.com/IndustryReports/About.do (login required).

Executive Office of the President, Office of Management and Budget. North American Industry Classification System (manual), United States, 1997. U.S. Government Printing Office, Washington, D.C.

Hall, C., A. Hodges and J. Haydu. 2005. Economic Impacts of the Green Industry in the United States. Final report to the National Urban and Community Forestry Advisory Committee (USDA/NUCFAC). Available at http://www.utextension.utk.edu/hbin.greenimpact.html.

Haydu, John J., Richard C. Beeson, and Jean Caron. 2004. Economic Analysis of Five Irrigation Technologies for Container-grown Viburnum odoratissimum. Acta Horticulturae 664:309-316.

Henry, Mark S. 1999. Landscaping Quality and the Price of Single Family Houses: Further Evidence from Home Sales in Greenville, South Carolina. Journal of Environmental Horticulture 17(1):25-30.

Lawn \& Landscape Magazine. 2004. 2004 State of the Industry Report (October 13). Available at http://www.lawnandlandscape.com.

MIG, Inc. 1999. Implan Professional, version 2.0, Social Accounting \& Impact Analysis Software: User's Guide, Analysis Guide and Data Guide. Stillwater, MN (April).

MIG, Inc. 2004. Implan 200150 State Data Package. Stillwater, MN (January).

Miller, R.E. and P.D. Blair. 1985. Input-output Analysis: Foundations and Extensions. Englewood Cliffs, NJ: Prentice-Hall.

National Golf Foundation. 2005. Number of U.S. golf facilities. Jupiter, FL. http://www.ngf.org/cgi/home.asp

Orland, B., J. Vining and A. Ebreo. 1992. The Effect of Street Trees on Perceived Values of Residential Property. Environment and Behavior 24(3):298-325. 
University of Florida. 2005. Sod Producer Survey, 2005. Unpublished data. Institute of Food \& Agricultural Sciences, University of Florida, Gainesville, FL.

U.S. Census Bureau. 2003. Farm Machinery and Lawn and Garden Equipment Manufacturing: 2002. Current Industrial Reports MA333A(02)-1. United States Department of Commerce, Washington, D.C. (August).

U.S. Census Bureau. 2004a. 2002 County Business Patterns, EPCD, County \& State Database on NAICS Basis. United States Department of Commerce, Washington, D.C. Available online at http://www.census.gov/epcd/cbp/view/cbpview.html (accessed December 2004).

U.S. Census Bureau. 2004b. Annual Benchmark Report for Retail Trade and Food Services: January 1992 through February 2004. Current Business Reports BR/03-A. U.S. Department of Commerce, Washington, D.C. (March).

U.S. Census Bureau. 2004c. Amusement, Gambling, and Recreation Industries, 2002 Economic Census, Arts, Entertainment, and Recreation Industry Series, EC02-711-03. United States Department of Commerce, Washington, D.C. (August).

U.S. Census Bureau. 2004d. Annual Benchmark Report for Wholesale Trade: January 1992 through December 2003. Current Business Reports BW/03-A. United States Department of Commerce, Washington, D.C. (March).

U.S. Census Bureau. 2004e. Annual Estimates of the Population for the United States and States, and for Puerto Rico. April 1, 2000 to July 1, 2004 (NST-EST2004-01). Population Division, Census Bureau, Washington, D.C. (December 22).

U.S. Census Bureau. 2004f. Lawn and Garden Equipment \& Supplies Stores, 2002 Economic Census, Retail Trade Industry Series, EC02-441-08. United States Department of Commerce, Washington, D.C. (September).

U.S. Census Bureau. 2004g. Services to Buildings and Dwellings, 2002 Economic Census, Administrative and Support and Waste Management and Remedial Services Industry Series, EC02-561-07. United States Department of Commerce, Washington, D.C. (June).

U.S. Census Bureau. 2005. 2002 Economic Census Industry Report Series for U.S. Totals. United States Department of Commerce, Washington, D.C.

U.S. Department of Agriculture, National Agricultural Statistics Service. 2004. 2002 Census of Agriculture. United States Summary and State Data, Vol. 1, Geographic Area Series, Part 51, AC-02-A-51. United States Department of Agriculture, Washington, D.C. (June).

U.S. Department of Agriculture. 2005. Floriculture and Nursery Crops Outlook. FLO-04. Available online at http://usda.mannlib.cornell.edu/reports/erssor/specialty/flo-bb/flo04.pdf

U.S. Department of Commerce. 2005. Gross Domestic Product: Implicit Price Deflator, 1970-2005, Quarterly. Available at http://research.stlouisfed.org/fred/data/gdp/gdpdef.

U.S. Department of Labor. Standard Industrial Classification (SIC) System Electronic Search Engine. Available online at http://www.osha.gov/pls/imis/sicsearch.html. 


\section{Appendix A-Economic Multipliers}

Table A-1. Multipliers for sod farms (nursery and greenhouse sector).

\begin{tabular}{|c|c|c|c|c|c|c|c|c|c|}
\hline \multirow[t]{2}{*}{ State } & \multicolumn{3}{|c|}{$\begin{array}{c}\text { Output } \\
\text { (dollars per dollar output) }\end{array}$} & \multicolumn{3}{|c|}{$\begin{array}{c}\text { Employment } \\
\text { (jobs per million dollars output) }\end{array}$} & \multicolumn{3}{|c|}{$\begin{array}{c}\text { Value Added } \\
\text { (dollars per dollar output) }\end{array}$} \\
\hline & Direct & Indirect & Induced & Direct & Indirect & Induced & Direct & Indirect & Induced \\
\hline Alabama & 1.0000 & 0.0138 & 0.9627 & 10.0716 & 0.1517 & 12.4493 & 0.9806 & 0.0087 & 0.5680 \\
\hline Alaska & 1.0000 & 0.2405 & 0.6367 & 6.9822 & 2.2494 & 7.9460 & 0.5387 & 0.1286 & 0.4360 \\
\hline Arizona & 1.0000 & 0.0887 & 1.1240 & 4.7669 & 1.1851 & 13.2398 & 0.8576 & 0.0523 & 0.6795 \\
\hline Arkansas & 1.0000 & 0.0686 & 0.8536 & 8.8633 & 0.8414 & 11.8816 & 0.9002 & 0.0357 & 0.4852 \\
\hline California & 1.0000 & 0.2452 & 1.2352 & 7.6564 & 2.5024 & 12.3251 & 0.7122 & 0.1381 & 0.7684 \\
\hline Colorado & 1.0000 & 0.2781 & 1.1559 & 5.1514 & 2.8823 & 12.7265 & 0.6105 & 0.1587 & 0.7082 \\
\hline Connecticut & 1.0000 & 0.0123 & 0.9990 & 11.9537 & 0.1086 & 9.8177 & 0.9806 & 0.0082 & 0.6279 \\
\hline Delaware & 1.0000 & 0.0107 & 0.8625 & 5.2486 & 0.1031 & 9.5756 & 0.9806 & 0.0058 & 0.4777 \\
\hline Florida & 1.0000 & 0.0506 & 1.3196 & 11.0630 & 0.6775 & 15.6132 & 0.9340 & 0.0326 & 0.8040 \\
\hline Georgia & 1.0000 & 0.0138 & 1.2438 & 6.7008 & 0.1384 & 13.9947 & 0.9806 & 0.0085 & 0.7596 \\
\hline Hawaii & 1.0000 & 0.0461 & 1.2567 & 15.2817 & 0.5506 & 16.0437 & 0.9262 & 0.0283 & 0.8468 \\
\hline Idaho & 1.0000 & 0.0121 & 1.0397 & 5.8911 & 0.1811 & 15.0342 & 0.9806 & 0.0073 & 0.6278 \\
\hline Illinois & 1.0000 & 0.2825 & 1.1046 & 5.5685 & 2.2010 & 11.4449 & 0.6263 & 0.1513 & 0.6655 \\
\hline Indiana & 1.0000 & 0.2931 & 0.7993 & 6.9067 & 2.8990 & 9.6792 & 0.5697 & 0.1482 & 0.4550 \\
\hline Iowa & 1.0000 & 0.3099 & 0.6446 & 4.3094 & 3.5665 & 8.5764 & 0.4743 & 0.1629 & 0.3721 \\
\hline Kansas & 1.0000 & 0.4025 & 0.7166 & 4.3825 & 3.8081 & 9.1713 & 0.4222 & 0.1964 & 0.4150 \\
\hline Kentucky & 1.0000 & 0.0590 & 0.8568 & 15.7775 & 0.7674 & 10.8581 & 0.9111 & 0.0324 & 0.4945 \\
\hline Louisiana & 1.0000 & 0.1925 & 0.8690 & 11.2600 & 2.0092 & 11.7970 & 0.6971 & 0.1000 & 0.5193 \\
\hline Maine & 1.0000 & 0.1089 & 0.9014 & 12.5596 & 1.5805 & 12.6316 & 0.7853 & 0.0638 & 0.5372 \\
\hline Maryland & 1.0000 & 0.0556 & 1.3375 & 8.6240 & 0.5121 & 15.0707 & 0.9042 & 0.0358 & 0.8800 \\
\hline Massachusetts & 1.0000 & 0.2388 & 0.9664 & 19.7582 & 2.2071 & 9.7408 & 0.6108 & 0.1449 & 0.6075 \\
\hline Michigan & 1.0000 & 0.3241 & 0.8163 & 9.3898 & 3.2341 & 8.9356 & 0.5090 & 0.1811 & 0.4717 \\
\hline Minnesota & 1.0000 & 0.3785 & 0.9383 & 5.3138 & 3.4583 & 10.6843 & 0.4687 & 0.2027 & 0.5559 \\
\hline Mississippi & 1.0000 & 0.0140 & 0.8944 & 12.0558 & 0.1667 & 12.7023 & 0.9806 & 0.0074 & 0.5274 \\
\hline Missouri & 1.0000 & 0.3312 & 0.9235 & 11.9260 & 3.9309 & 11.4019 & 0.5243 & 0.1858 & 0.5467 \\
\hline Montana & 1.0000 & 0.2274 & 0.6610 & 5.8150 & 2.6883 & 9.9243 & 0.5392 & 0.1098 & 0.3944 \\
\hline Nebraska & 1.0000 & 0.2772 & 0.7011 & 3.0697 & 3.0804 & 9.3944 & 0.4488 & 0.1491 & 0.4114 \\
\hline Nevada & 1.0000 & 0.0091 & 1.1471 & 6.7480 & 0.1111 & 12.6026 & 0.9806 & 0.0054 & 0.7101 \\
\hline New Hampshire & 1.0000 & 0.2508 & 0.8996 & 17.4168 & 2.9685 & 10.4967 & 0.6143 & 0.1508 & 0.5304 \\
\hline New Jersey & 1.0000 & 0.1144 & 0.8814 & 14.6176 & 0.9297 & 8.5973 & 0.8390 & 0.0667 & 0.5537 \\
\hline New Mexico & 1.0000 & 0.0641 & 1.0139 & 5.4760 & 0.8715 & 14.3807 & 0.9031 & 0.0337 & 0.6365 \\
\hline New York & 1.0000 & 0.1471 & 0.8323 & 8.4013 & 1.1874 & 8.2927 & 0.7335 & 0.0879 & 0.5313 \\
\hline North Carolina & 1.0000 & 0.0135 & 1.0810 & 5.0395 & 0.1432 & 13.1926 & 0.9806 & 0.0086 & 0.6360 \\
\hline North Dakota & 1.0000 & 0.2983 & 0.4694 & 3.7344 & 2.9328 & 6.9018 & 0.3862 & 0.1378 & 0.2775 \\
\hline Ohio & 1.0000 & 0.2732 & 0.7432 & 10.3194 & 2.7486 & 8.8566 & 0.5800 & 0.1412 & 0.4321 \\
\hline Oklahoma & 1.0000 & 0.3647 & 0.9112 & 12.8865 & 4.7810 & 12.2900 & 0.5553 & 0.1878 & 0.5383 \\
\hline Oregon & 1.0000 & 0.3294 & 0.9778 & 13.8836 & 4.2927 & 12.2179 & 0.6255 & 0.1961 & 0.5969 \\
\hline Pennsylvania & 1.0000 & 0.1821 & 1.1103 & 10.6688 & 1.6047 & 12.2233 & 0.7525 & 0.1004 & 0.6635 \\
\hline Rhode Island & 1.0000 & 0.1877 & 0.6967 & 15.3068 & 2.0839 & 8.4742 & 0.6193 & 0.1073 & 0.4414 \\
\hline South Carolina & 1.0000 & 0.0127 & 0.9736 & 10.8809 & 0.1444 & 12.6953 & 0.9806 & 0.0083 & 0.5816 \\
\hline South Dakota & 1.0000 & 0.2270 & 0.6427 & 3.3676 & 2.5886 & 9.2002 & 0.5031 & 0.1226 & 0.3712 \\
\hline Tennessee & 1.0000 & 0.3834 & 0.9055 & 27.1515 & 5.4979 & 10.7726 & 0.5292 & 0.2087 & 0.5297 \\
\hline Texas & 1.0000 & 0.3805 & 1.1091 & 11.9364 & 3.7715 & 12.0449 & 0.5917 & 0.2066 & 0.6634 \\
\hline Utah & 1.0000 & 0.0957 & 1.3284 & 9.4921 & 1.0876 & 17.5553 & 0.8639 & 0.0523 & 0.7882 \\
\hline Vermont & 1.0000 & 0.1314 & 0.8535 & 7.6434 & 1.8912 & 11.9415 & 0.7577 & 0.0764 & 0.5149 \\
\hline Virginia & 1.0000 & 0.1930 & 1.0200 & 15.3364 & 2.0653 & 11.8871 & 0.6868 & 0.1130 & 0.6547 \\
\hline Washington & 1.0000 & 0.1196 & 1.0418 & 10.8278 & 1.3185 & 11.5996 & 0.8467 & 0.0689 & 0.6358 \\
\hline West Virginia & 1.0000 & 0.5103 & 0.4108 & 34.0957 & 7.9856 & 5.9567 & 0.2380 & 0.2247 & 0.2502 \\
\hline Wisconsin & 1.0000 & 0.2804 & 0.8099 & 7.2554 & 3.0855 & 10.0009 & 0.5565 & 0.1514 & 0.4698 \\
\hline Wyoming & 1.0000 & 0.2662 & 0.6148 & 5.2722 & 3.1226 & 8.8150 & 0.5680 & 0.1310 & 0.3745 \\
\hline
\end{tabular}

Source: Implan 50 state data package, 2001 (MIG, Inc. 2004). 
Table A-2. Multipliers for lawncare services (services to buildings sector).

\begin{tabular}{|c|c|c|c|c|c|c|c|c|c|}
\hline \multirow[t]{2}{*}{ State } & \multicolumn{3}{|c|}{$\begin{array}{c}\text { Output } \\
\text { (dollars per dollar output) } \\
\end{array}$} & \multicolumn{3}{|c|}{$\begin{array}{c}\text { Employment } \\
\text { (jobs per million dollars output) }\end{array}$} & \multicolumn{3}{|c|}{$\begin{array}{c}\text { Value Added } \\
\text { (dollars per dollar output) } \\
\end{array}$} \\
\hline & Direct & Indirect & Induced & Direct & Indirect & Induced & Direct & Indirect & Induced \\
\hline Alabama & 1.000 & 0.247 & 0.939 & 36.6 & 3.7 & 12.3 & 0.665 & 0.159 & 0.567 \\
\hline Alaska & 1.000 & 0.198 & 0.793 & 33.6 & 2.8 & 9.8 & 0.679 & 0.120 & 0.535 \\
\hline Arizona & 1.000 & 0.233 & 1.135 & 30.3 & 3.1 & 13.6 & 0.695 & 0.150 & 0.701 \\
\hline Arkansas & 1.000 & 0.212 & 0.839 & 35.3 & 3.4 & 11.7 & 0.671 & 0.122 & 0.486 \\
\hline California & 1.000 & 0.273 & 1.414 & 27.2 & 3.1 & 14.3 & 0.710 & 0.175 & 0.887 \\
\hline Colorado & 1.000 & 0.257 & 1.356 & 31.0 & 3.2 & 15.1 & 0.691 & 0.164 & 0.840 \\
\hline Connecticut & 1.000 & 0.248 & 1.041 & 27.9 & 2.9 & 10.5 & 0.706 & 0.169 & 0.666 \\
\hline Delaware & 1.000 & 0.200 & 0.820 & 33.3 & 2.8 & 9.7 & 0.681 & 0.124 & 0.486 \\
\hline Florida & 1.000 & 0.272 & 1.299 & 30.0 & 3.7 & 15.4 & 0.696 & 0.182 & 0.804 \\
\hline Georgia & 1.000 & 0.260 & 1.287 & 30.0 & 3.2 & 14.6 & 0.696 & 0.170 & 0.803 \\
\hline Hawaii & 1.000 & 0.240 & 1.179 & 32.5 & 3.5 & 15.1 & 0.684 & 0.157 & 0.795 \\
\hline Idaho & 1.000 & 0.240 & 0.950 & 34.8 & 4.0 & 13.9 & 0.674 & 0.152 & 0.579 \\
\hline Illinois & 1.000 & 0.253 & 1.373 & 26.9 & 3.0 & 14.3 & 0.711 & 0.157 & 0.830 \\
\hline Indiana & 1.000 & 0.229 & 1.002 & 32.9 & 3.4 & 12.3 & 0.682 & 0.134 & 0.578 \\
\hline Iowa & 1.000 & 0.219 & 0.897 & 35.0 & 3.5 & 12.1 & 0.673 & 0.129 & 0.522 \\
\hline Kansas & 1.000 & 0.238 & 1.029 & 33.3 & 3.5 & 13.2 & 0.681 & 0.140 & 0.601 \\
\hline Kentucky & 1.000 & 0.225 & 0.846 & 34.7 & 3.6 & 10.9 & 0.674 & 0.136 & 0.498 \\
\hline Louisiana & 1.000 & 0.257 & 0.936 & 39.2 & 4.1 & 12.7 & 0.652 & 0.152 & 0.564 \\
\hline Maine & 1.000 & 0.207 & 0.921 & 35.3 & 3.4 & 13.1 & 0.671 & 0.129 & 0.562 \\
\hline Maryland & 1.000 & 0.246 & 1.357 & 31.6 & 3.2 & 15.5 & 0.689 & 0.163 & 0.897 \\
\hline Massachusetts & 1.000 & 0.251 & 1.173 & 28.6 & 3.1 & 12.0 & 0.703 & 0.163 & 0.741 \\
\hline Michigan & 1.000 & 0.241 & 1.064 & 29.0 & 3.2 & 11.8 & 0.701 & 0.149 & 0.621 \\
\hline Minnesota & 1.000 & 0.266 & 1.286 & 31.2 & 3.5 & 14.7 & 0.690 & 0.164 & 0.764 \\
\hline Mississippi & 1.000 & 0.237 & 0.826 & 39.8 & 3.8 & 11.6 & 0.650 & 0.140 & 0.490 \\
\hline Missouri & 1.000 & 0.273 & 1.182 & 35.1 & 3.9 & 14.6 & 0.672 & 0.167 & 0.704 \\
\hline Montana & 1.000 & 0.205 & 0.816 & 43.3 & 3.6 & 12.2 & 0.633 & 0.117 & 0.489 \\
\hline Nebraska & 1.000 & 0.232 & 1.016 & 36.6 & 3.9 & 13.7 & 0.665 & 0.140 & 0.602 \\
\hline Nevada & 1.000 & 0.189 & 1.004 & 25.7 & 2.5 & 11.1 & 0.717 & 0.122 & 0.629 \\
\hline New Hampshire & 1.000 & 0.250 & 1.054 & 32.3 & 3.5 & 12.4 & 0.685 & 0.157 & 0.628 \\
\hline New Jersey & 1.000 & 0.266 & 1.033 & 28.9 & 2.9 & 10.1 & 0.702 & 0.174 & 0.653 \\
\hline New Mexico & 1.000 & 0.242 & 0.956 & 36.2 & 3.9 & 13.6 & 0.667 & 0.147 & 0.601 \\
\hline New York & 1.000 & 0.217 & 0.989 & 23.7 & 2.4 & 9.9 & 0.726 & 0.143 & 0.635 \\
\hline North Carolina & 1.000 & 0.252 & 1.097 & 34.0 & 3.4 & 13.6 & 0.677 & 0.163 & 0.666 \\
\hline North Dakota & 1.000 & 0.199 & 0.761 & 37.9 & 3.6 & 11.2 & 0.659 & 0.111 & 0.449 \\
\hline Ohio & 1.000 & 0.251 & 0.954 & 32.7 & 3.6 & 11.5 & 0.683 & 0.150 & 0.560 \\
\hline Oklahoma & 1.000 & 0.281 & 1.106 & 37.5 & 4.4 & 15.0 & 0.661 & 0.166 & 0.658 \\
\hline Oregon & 1.000 & 0.282 & 1.104 & 30.1 & 4.1 & 13.9 & 0.696 & 0.178 & 0.677 \\
\hline Pennsylvania & 1.000 & 0.259 & 1.222 & 28.9 & 3.3 & 13.5 & 0.701 & 0.161 & 0.736 \\
\hline Rhode Island & 1.000 & 0.183 & 0.841 & 31.3 & 2.6 & 10.3 & 0.690 & 0.114 & 0.538 \\
\hline South Carolina & 1.000 & 0.228 & 0.935 & 34.4 & 3.4 & 12.4 & 0.676 & 0.148 & 0.573 \\
\hline South Dakota & 1.000 & 0.229 & 0.861 & 47.5 & 3.9 & 12.4 & 0.613 & 0.133 & 0.504 \\
\hline Tennessee & 1.000 & 0.259 & 1.151 & 29.4 & 3.9 & 13.7 & 0.699 & 0.155 & 0.681 \\
\hline Texas & 1.000 & 0.309 & 1.284 & 33.7 & 3.8 & 13.9 & 0.679 & 0.190 & 0.772 \\
\hline Utah & 1.000 & 0.274 & 1.321 & 35.3 & 4.1 & 17.6 & 0.671 & 0.169 & 0.795 \\
\hline Vermont & 1.000 & 0.222 & 0.911 & 35.4 & 3.5 & 12.9 & 0.670 & 0.139 & 0.560 \\
\hline Virginia & 1.000 & 0.250 & 1.172 & 34.0 & 3.4 & 13.7 & 0.677 & 0.157 & 0.750 \\
\hline Washington & 1.000 & 0.250 & 1.056 & 30.9 & 3.1 & 11.9 & 0.692 & 0.159 & 0.649 \\
\hline West Virginia & 1.000 & 0.217 & 0.722 & 36.0 & 4.0 & 10.3 & 0.668 & 0.114 & 0.434 \\
\hline Wisconsin & 1.000 & 0.228 & 1.023 & 30.0 & 3.4 & 12.8 & 0.696 & 0.137 & 0.598 \\
\hline Wyoming & 1.000 & 0.214 & 0.721 & 39.3 & 3.6 & 10.3 & 0.652 & 0.123 & 0.440 \\
\hline
\end{tabular}

Source: Implan 50 state data package, 2001 (MIG, Inc. 2004). 
Table A-3. Multipliers for lawncare retailing (building materials and garden supplies stores sector).

\begin{tabular}{|c|c|c|c|c|c|c|c|c|c|}
\hline \multirow[t]{2}{*}{ State } & \multicolumn{3}{|c|}{$\begin{array}{c}\text { Output } \\
\text { (dollars per dollar output) } \\
\end{array}$} & \multicolumn{3}{|c|}{$\begin{array}{c}\text { Employment } \\
\text { (jobs per million dollars output) }\end{array}$} & \multicolumn{3}{|c|}{$\begin{array}{c}\text { Value Added } \\
\text { (dollars per dollar output) }\end{array}$} \\
\hline & Direct & Indirect & Induced & Direct & Indirect & Induced & Direct & Indirect & Induced \\
\hline Alabama & 1.000 & 0.214 & 0.943 & 17.0 & 2.6 & 12.8 & 0.674 & 0.128 & 0.586 \\
\hline Alaska & 1.000 & 0.202 & 0.822 & 15.2 & 2.3 & 10.4 & 0.684 & 0.122 & 0.566 \\
\hline Arizona & 1.000 & 0.268 & 1.167 & 15.8 & 2.9 & 14.6 & 0.680 & 0.173 & 0.743 \\
\hline Arkansas & 1.000 & 0.218 & 0.845 & 18.8 & 2.7 & 12.2 & 0.664 & 0.129 & 0.503 \\
\hline California & 1.000 & 0.298 & 1.414 & 14.5 & 2.7 & 14.7 & 0.687 & 0.193 & 0.905 \\
\hline Colorado & 1.000 & 0.287 & 1.416 & 14.8 & 2.7 & 16.2 & 0.686 & 0.187 & 0.894 \\
\hline Connecticut & 1.000 & 0.267 & 1.051 & 13.3 & 2.2 & 11.0 & 0.694 & 0.180 & 0.694 \\
\hline Delaware & 1.000 & 0.194 & 0.847 & 15.0 & 2.0 & 10.5 & 0.685 & 0.121 & 0.524 \\
\hline Florida & 1.000 & 0.289 & 1.311 & 15.8 & 3.1 & 16.0 & 0.680 & 0.187 & 0.828 \\
\hline Georgia & 1.000 & 0.277 & 1.303 & 14.2 & 2.7 & 15.2 & 0.689 & 0.180 & 0.826 \\
\hline Hawaii & 1.000 & 0.229 & 1.183 & 15.3 & 2.5 & 15.8 & 0.683 & 0.144 & 0.820 \\
\hline Idaho & 1.000 & 0.225 & 0.950 & 14.8 & 3.0 & 14.4 & 0.686 & 0.138 & 0.595 \\
\hline Illinois & 1.000 & 0.306 & 1.387 & 16.2 & 2.7 & 14.8 & 0.678 & 0.197 & 0.852 \\
\hline Indiana & 1.000 & 0.245 & 1.030 & 16.8 & 2.7 & 13.0 & 0.675 & 0.149 & 0.609 \\
\hline Iowa & 1.000 & 0.210 & 0.912 & 16.8 & 2.7 & 12.6 & 0.675 & 0.127 & 0.545 \\
\hline Kansas & 1.000 & 0.247 & 1.045 & 17.5 & 2.8 & 14.0 & 0.671 & 0.149 & 0.624 \\
\hline Kentucky & 1.000 & 0.207 & 0.830 & 16.9 & 2.5 & 11.0 & 0.674 & 0.126 & 0.499 \\
\hline Louisiana & 1.000 & 0.235 & 0.985 & 17.3 & 2.9 & 14.0 & 0.672 & 0.142 & 0.613 \\
\hline Maine & 1.000 & 0.187 & 0.934 & 16.9 & 2.5 & 13.8 & 0.675 & 0.115 & 0.592 \\
\hline Maryland & 1.000 & 0.255 & 1.368 & 15.2 & 2.6 & 16.0 & 0.684 & 0.165 & 0.924 \\
\hline Massachusetts & 1.000 & 0.271 & 1.182 & 13.4 & 2.4 & 12.4 & 0.693 & 0.179 & 0.765 \\
\hline Michigan & 1.000 & 0.261 & 1.083 & 15.2 & 2.6 & 12.4 & 0.683 & 0.169 & 0.650 \\
\hline Minnesota & 1.000 & 0.296 & 1.311 & 16.2 & 2.9 & 15.4 & 0.678 & 0.189 & 0.794 \\
\hline Mississippi & 1.000 & 0.198 & 0.846 & 18.2 & 2.6 & 12.4 & 0.667 & 0.113 & 0.515 \\
\hline Missouri & 1.000 & 0.288 & 1.218 & 16.3 & 3.2 & 15.5 & 0.677 & 0.183 & 0.739 \\
\hline Montana & 1.000 & 0.174 & 0.841 & 18.1 & 2.5 & 13.0 & 0.668 & 0.101 & 0.518 \\
\hline Nebraska & 1.000 & 0.242 & 1.057 & 18.1 & 3.0 & 14.8 & 0.667 & 0.149 & 0.641 \\
\hline Nevada & 1.000 & 0.221 & 0.995 & 14.0 & 2.3 & 11.3 & 0.690 & 0.144 & 0.642 \\
\hline New Hampshire & 1.000 & 0.231 & 1.073 & 13.8 & 2.5 & 13.3 & 0.691 & 0.148 & 0.660 \\
\hline New Jersey & 1.000 & 0.278 & 1.040 & 13.6 & 2.4 & 10.6 & 0.692 & 0.183 & 0.678 \\
\hline New Mexico & 1.000 & 0.238 & 1.002 & 17.3 & 3.2 & 14.9 & 0.672 & 0.142 & 0.654 \\
\hline New York & 1.000 & 0.283 & 0.993 & 15.3 & 2.2 & 10.3 & 0.683 & 0.191 & 0.651 \\
\hline North Carolina & 1.000 & 0.229 & 1.088 & 16.3 & 2.6 & 13.9 & 0.677 & 0.143 & 0.676 \\
\hline North Dakota & 1.000 & 0.192 & 0.767 & 18.5 & 2.6 & 11.7 & 0.665 & 0.107 & 0.467 \\
\hline Ohio & 1.000 & 0.265 & 0.952 & 16.7 & 2.9 & 11.8 & 0.675 & 0.165 & 0.572 \\
\hline Oklahoma & 1.000 & 0.251 & 1.110 & 18.2 & 3.2 & 15.6 & 0.667 & 0.149 & 0.678 \\
\hline Oregon & 1.000 & 0.280 & 1.060 & 16.1 & 3.2 & 13.7 & 0.679 & 0.179 & 0.665 \\
\hline Pennsylvania & 1.000 & 0.297 & 1.212 & 16.8 & 2.9 & 13.8 & 0.675 & 0.187 & 0.744 \\
\hline Rhode Island & 1.000 & 0.166 & 0.841 & 14.6 & 1.7 & 10.7 & 0.687 & 0.106 & 0.560 \\
\hline South Carolina & 1.000 & 0.199 & 0.935 & 16.3 & 2.3 & 12.9 & 0.678 & 0.121 & 0.590 \\
\hline South Dakota & 1.000 & 0.189 & 0.921 & 18.5 & 2.4 & 13.8 & 0.665 & 0.112 & 0.554 \\
\hline Tennessee & 1.000 & 0.252 & 1.132 & 15.8 & 2.7 & 14.0 & 0.680 & 0.157 & 0.685 \\
\hline Texas & 1.000 & 0.275 & 1.276 & 15.8 & 2.7 & 14.2 & 0.680 & 0.172 & 0.779 \\
\hline Utah & 1.000 & 0.278 & 1.344 & 16.4 & 3.5 & 18.5 & 0.677 & 0.170 & 0.829 \\
\hline Vermont & 1.000 & 0.221 & 0.939 & 16.1 & 2.8 & 13.8 & 0.678 & 0.136 & 0.599 \\
\hline Virginia & 1.000 & 0.268 & 1.213 & 16.6 & 2.7 & 14.6 & 0.676 & 0.171 & 0.791 \\
\hline Washington & 1.000 & 0.243 & 1.011 & 14.8 & 2.4 & 11.7 & 0.685 & 0.154 & 0.636 \\
\hline West Virginia & 1.000 & 0.179 & 0.691 & 18.5 & 2.3 & 10.1 & 0.666 & 0.102 & 0.427 \\
\hline Wisconsin & 1.000 & 0.246 & 1.033 & 16.2 & 2.8 & 13.3 & 0.678 & 0.152 & 0.621 \\
\hline Wyoming & 1.000 & 0.196 & 0.745 & 17.7 & 2.5 & 11.3 & 0.670 & 0.115 & 0.475 \\
\hline
\end{tabular}

Source: Implan 50 state data package, 2001 (MIG, Inc. 2004). 
Table A-4. Multipliers for lawn and garden equipment manufacturing.

\begin{tabular}{|c|c|c|c|c|c|c|c|c|c|}
\hline \multirow[t]{2}{*}{ State } & \multicolumn{3}{|c|}{$\begin{array}{c}\text { Output } \\
\text { (dollars per dollar output) }\end{array}$} & \multicolumn{3}{|c|}{$\begin{array}{c}\text { Employment } \\
\text { (jobs per million dollars output) }\end{array}$} & \multicolumn{3}{|c|}{$\begin{array}{c}\text { Value Added } \\
\text { (dollars per dollar output) }\end{array}$} \\
\hline & Direct & Indirect & Induced & Direct & Indirect & Induced & Direct & Indirect & Induced \\
\hline Alabama & 1.0000 & 0.4429 & 0.4896 & 3.2900 & 3.2506 & 6.4473 & 0.2642 & 0.1947 & 0.2955 \\
\hline Alaska & 0.0000 & 0.0000 & 0.0000 & 0.0000 & 0.0000 & 0.0000 & 0.0000 & 0.0000 & 0.0000 \\
\hline Arizona & 1.0000 & 0.3597 & 0.5697 & 3.3277 & 2.9147 & 6.8604 & 0.2575 & 0.1948 & 0.3502 \\
\hline Arkansas & 1.0000 & 0.4077 & 0.3606 & 3.7138 & 3.4109 & 5.1010 & 0.1886 & 0.1809 & 0.2091 \\
\hline California & 1.0000 & 0.4251 & 0.7547 & 3.2247 & 3.0416 & 7.6171 & 0.2758 & 0.2348 & 0.4736 \\
\hline Colorado & 1.0000 & 0.4800 & 0.7424 & 3.4502 & 3.2811 & 8.2543 & 0.2356 & 0.2564 & 0.4580 \\
\hline Connecticut & 0.0000 & 0.0000 & 0.0000 & 0.0000 & 0.0000 & 0.0000 & 0.0000 & 0.0000 & 0.0000 \\
\hline Delaware & 0.0000 & 0.0000 & 0.0000 & 0.0000 & 0.0000 & 0.0000 & 0.0000 & 0.0000 & 0.0000 \\
\hline Florida & 1.0000 & 0.4004 & 0.6010 & 3.6538 & 3.3020 & 7.2125 & 0.1993 & 0.2208 & 0.3723 \\
\hline Georgia & 1.0000 & 0.4893 & 0.6673 & 3.4603 & 3.4373 & 7.6435 & 0.2338 & 0.2472 & 0.4158 \\
\hline Hawaii & 0.0000 & 0.0000 & 0.0000 & 0.0000 & 0.0000 & 0.0000 & 0.0000 & 0.0000 & 0.0000 \\
\hline Idaho & 0.0000 & 0.0000 & 0.0000 & 0.0000 & 0.0000 & 0.0000 & 0.0000 & 0.0000 & 0.0000 \\
\hline Illinois & 1.0000 & 0.5983 & 0.8371 & 3.2753 & 3.7211 & 8.7408 & 0.2668 & 0.3064 & 0.5073 \\
\hline Indiana & 1.0000 & 0.5382 & 0.5580 & 3.3915 & 3.6417 & 6.8133 & 0.2461 & 0.2472 & 0.3202 \\
\hline Iowa & 1.0000 & 0.4463 & 0.4566 & 3.4311 & 3.4737 & 6.1325 & 0.2390 & 0.2057 & 0.2657 \\
\hline Kansas & 1.0000 & 0.3559 & 0.5204 & 3.1962 & 2.8828 & 6.6860 & 0.2809 & 0.1789 & 0.3016 \\
\hline Kentucky & 1.0000 & 0.4535 & 0.4209 & 3.4025 & 3.3179 & 5.4188 & 0.2441 & 0.1994 & 0.2467 \\
\hline Louisiana & 1.0000 & 0.2969 & 0.4392 & 3.3948 & 2.5738 & 6.0465 & 0.2455 & 0.1518 & 0.2653 \\
\hline Maine & 1.0000 & 0.2612 & 0.4107 & 3.4019 & 2.4644 & 5.8353 & 0.2442 & 0.1391 & 0.2480 \\
\hline Maryland & 1.0000 & 0.3996 & 0.7288 & 3.1810 & 2.6701 & 8.3104 & 0.2836 & 0.2056 & 0.4839 \\
\hline Massachusetts & 1.0000 & 0.4179 & 0.6047 & 3.3937 & 2.7618 & 6.1291 & 0.2457 & 0.2363 & 0.3823 \\
\hline Michigan & 1.0000 & 0.3944 & 0.6655 & 2.6073 & 2.5040 & 7.2272 & 0.3859 & 0.1968 & 0.3826 \\
\hline Minnesota & 1.0000 & 0.4012 & 0.6899 & 3.2360 & 3.0586 & 7.8939 & 0.2738 & 0.2220 & 0.4103 \\
\hline Mississippi & 1.0000 & 0.4277 & 0.3940 & 3.4747 & 3.2135 & 5.6533 & 0.2313 & 0.1739 & 0.2351 \\
\hline Missouri & 1.0000 & 0.5442 & 0.6373 & 3.5221 & 4.0671 & 7.9353 & 0.2228 & 0.2629 & 0.3796 \\
\hline Montana & 0.0000 & 0.0000 & 0.0000 & 0.0000 & 0.0000 & 0.0000 & 0.0000 & 0.0000 & 0.0000 \\
\hline Nebraska & 1.0000 & 0.3542 & 0.5503 & 3.1243 & 3.0915 & 7.4316 & 0.2937 & 0.1776 & 0.3248 \\
\hline Nevada & 0.0000 & 0.0000 & 0.0000 & 0.0000 & 0.0000 & 0.0000 & 0.0000 & 0.0000 & 0.0000 \\
\hline New Hampshire & 0.0000 & 0.0000 & 0.0000 & 0.0000 & 0.0000 & 0.0000 & 0.0000 & 0.0000 & 0.0000 \\
\hline New Jersey & 1.0000 & 0.3708 & 0.5236 & 3.1466 & 2.5061 & 5.1978 & 0.2898 & 0.2142 & 0.3335 \\
\hline New Mexico & 0.0000 & 0.0000 & 0.0000 & 0.0000 & 0.0000 & 0.0000 & 0.0000 & 0.0000 & 0.0000 \\
\hline New York & 1.0000 & 0.5104 & 0.5425 & 3.3149 & 3.0810 & 5.4801 & 0.2597 & 0.2684 & 0.3495 \\
\hline North Carolina & 1.0000 & 0.4225 & 0.6117 & 3.0507 & 3.0719 & 7.6010 & 0.3069 & 0.2013 & 0.3690 \\
\hline North Dakota & 1.0000 & 0.2540 & 0.3334 & 3.3571 & 2.4401 & 4.9355 & 0.2522 & 0.1223 & 0.1981 \\
\hline Ohio & 1.0000 & 0.3979 & 0.4646 & 3.2626 & 2.8137 & 5.5520 & 0.2691 & 0.1792 & 0.2709 \\
\hline Oklahoma & 1.0000 & 0.4274 & 0.5572 & 3.2947 & 3.3980 & 7.5753 & 0.2633 & 0.1922 & 0.3315 \\
\hline Oregon & 1.0000 & 0.4077 & 0.5265 & 3.4647 & 3.3702 & 6.6304 & 0.2330 & 0.2249 & 0.3235 \\
\hline Pennsylvania & 1.0000 & 0.4578 & 0.7085 & 3.0258 & 3.2440 & 7.8619 & 0.3113 & 0.2328 & 0.4260 \\
\hline Rhode Island & 0.0000 & 0.0000 & 0.0000 & 0.0000 & 0.0000 & 0.0000 & 0.0000 & 0.0000 & 0.0000 \\
\hline South Carolina & 1.0000 & 0.4208 & 0.4503 & 3.4422 & 3.1352 & 5.9891 & 0.2370 & 0.1870 & 0.2751 \\
\hline South Dakota & 1.0000 & 0.3119 & 0.4856 & 2.9975 & 2.7494 & 7.0347 & 0.3164 & 0.1506 & 0.2833 \\
\hline Tennessee & 1.0000 & 0.4867 & 0.6024 & 3.3143 & 3.6011 & 7.2425 & 0.2599 & 0.2271 & 0.3550 \\
\hline Texas & 1.0000 & 0.4963 & 0.6462 & 3.6373 & 3.4635 & 7.0829 & 0.2023 & 0.2581 & 0.3891 \\
\hline Utah & 1.0000 & 0.4710 & 0.7295 & 3.2165 & 3.8439 & 9.7837 & 0.2773 & 0.2235 & 0.4385 \\
\hline Vermont & 1.0000 & 0.2966 & 0.4488 & 3.1097 & 2.5556 & 6.3516 & 0.2963 & 0.1454 & 0.2732 \\
\hline Virginia & 1.0000 & 0.3582 & 0.5705 & 3.3473 & 2.6930 & 6.7013 & 0.2540 & 0.1853 & 0.3681 \\
\hline Washington & 1.0000 & 0.2971 & 0.4987 & 3.1437 & 2.3815 & 5.6182 & 0.2903 & 0.1682 & 0.3069 \\
\hline West Virginia & 0.0000 & 0.0000 & 0.0000 & 0.0000 & 0.0000 & 0.0000 & 0.0000 & 0.0000 & 0.0000 \\
\hline Wisconsin & 1.0000 & 0.4608 & 0.6226 & 2.8894 & 3.3055 & 7.7071 & 0.3356 & 0.2180 & 0.3622 \\
\hline Wyoming & 0.0000 & 0.0000 & 0.0000 & 0.0000 & 0.0000 & 0.0000 & 0.0000 & 0.0000 & 0.0000 \\
\hline
\end{tabular}

Source: Implan 50 state data package, 2001 (MIG, Inc. 2004). 
Table A-5. Multipliers for golf courses (amusement, gambling and recreation services).

\begin{tabular}{|c|c|c|c|c|c|c|c|c|c|}
\hline \multirow[t]{2}{*}{ State } & \multicolumn{3}{|c|}{$\begin{array}{c}\text { Output (dollars per dollar } \\
\text { output) }\end{array}$} & \multicolumn{3}{|c|}{$\begin{array}{c}\text { Employment (jobs per million } \\
\text { dollars output) }\end{array}$} & \multicolumn{3}{|c|}{$\begin{array}{c}\text { Value Added (dollars per } \\
\text { dollar output) }\end{array}$} \\
\hline & Direct & Indirect & Induced & Direct & Indirect & Induced & Direct & Indirect & Induced \\
\hline Alabama & 1.000 & 0.2592 & 0.8441 & 23.3 & 3.1 & 11.2 & 0.6160 & 0.1493 & 0.5130 \\
\hline Alaska & 1.000 & 0.2372 & 0.7732 & 14.0 & 2.8 & 9.7 & 0.6247 & 0.1398 & 0.5278 \\
\hline Arizona & 1.000 & 0.2940 & 1.0483 & 14.9 & 3.2 & 12.7 & 0.6238 & 0.1823 & 0.6497 \\
\hline Arkansas & 1.000 & 0.2437 & 0.7528 & 24.0 & 3.1 & 10.7 & 0.6153 & 0.1353 & 0.4385 \\
\hline California & 1.000 & 0.3474 & 1.2846 & 13.1 & 3.2 & 13.0 & 0.6256 & 0.2185 & 0.8090 \\
\hline Colorado & 1.000 & 0.3365 & 1.2910 & 12.4 & 3.5 & 14.4 & 0.6261 & 0.2077 & 0.7998 \\
\hline Connecticut & 1.000 & 0.3186 & 0.9282 & 11.6 & 2.9 & 9.4 & 0.6269 & 0.2053 & 0.5987 \\
\hline Delaware & 1.000 & 0.2183 & 0.7417 & 17.7 & 2.3 & 8.8 & 0.6212 & 0.1316 & 0.4395 \\
\hline Florida & 1.000 & 0.3229 & 1.2000 & 12.9 & 3.5 & 14.4 & 0.6257 & 0.2020 & 0.7452 \\
\hline Georgia & 1.000 & 0.3289 & 1.1697 & 18.8 & 3.3 & 13.4 & 0.6202 & 0.2036 & 0.7307 \\
\hline Hawaii & 1.000 & 0.2744 & 1.0683 & 15.6 & 3.4 & 14.0 & 0.6231 & 0.1652 & 0.7299 \\
\hline Idaho & 1.000 & 0.2738 & 0.8498 & 22.2 & 3.7 & 12.5 & 0.6170 & 0.1588 & 0.5218 \\
\hline Illinois & 1.000 & 0.3478 & 1.2607 & 12.3 & 3.3 & 13.2 & 0.6263 & 0.2141 & 0.7658 \\
\hline Indiana & 1.000 & 0.2635 & 0.9177 & 9.8 & 3.0 & 11.3 & 0.6286 & 0.1538 & 0.5306 \\
\hline Iowa & 1.000 & 0.2467 & 0.8235 & 10.1 & 3.1 & 11.1 & 0.6283 & 0.1410 & 0.4815 \\
\hline Kansas & 1.000 & 0.2745 & 0.9245 & 19.9 & 3.2 & 12.0 & 0.6191 & 0.1582 & 0.5404 \\
\hline Kentucky & 1.000 & 0.2369 & 0.7434 & 19.3 & 2.9 & 9.6 & 0.6197 & 0.1366 & 0.4381 \\
\hline Louisiana & 1.000 & 0.2587 & 0.8946 & 11.2 & 3.2 & 12.4 & 0.6273 & 0.1507 & 0.5439 \\
\hline Maine & 1.000 & 0.2293 & 0.8359 & 18.4 & 3.3 & 12.0 & 0.6205 & 0.1304 & 0.5121 \\
\hline Maryland & 1.000 & 0.3097 & 1.2477 & 18.6 & 3.2 & 14.3 & 0.6203 & 0.1932 & 0.8317 \\
\hline Massachusetts & 1.000 & 0.3178 & 1.0669 & 14.3 & 3.0 & 10.9 & 0.6244 & 0.2024 & 0.6776 \\
\hline Michigan & 1.000 & 0.2936 & 0.9620 & 14.2 & 3.1 & 10.7 & 0.6244 & 0.1798 & 0.5621 \\
\hline Minnesota & 1.000 & 0.3396 & 1.1835 & 20.1 & 3.6 & 13.6 & 0.6190 & 0.2063 & 0.7065 \\
\hline Mississippi & 1.000 & 0.2209 & 0.7554 & 12.2 & 2.8 & 10.9 & 0.6263 & 0.1208 & 0.4523 \\
\hline Missouri & 1.000 & 0.3192 & 1.0981 & 13.6 & 3.6 & 13.7 & 0.6250 & 0.1926 & 0.6558 \\
\hline Montana & 1.000 & 0.2205 & 0.7750 & 19.8 & 3.3 & 11.8 & 0.6193 & 0.1214 & 0.4674 \\
\hline Nebraska & 1.000 & 0.2740 & 0.9536 & 18.2 & 3.5 & 13.0 & 0.6208 & 0.1582 & 0.5660 \\
\hline Nevada & 1.000 & 0.2543 & 0.9246 & 9.8 & 2.7 & 10.3 & 0.6285 & 0.1586 & 0.5828 \\
\hline New Hampshire & 1.000 & 0.2772 & 0.9494 & 18.6 & 3.0 & 11.4 & 0.6203 & 0.1680 & 0.5689 \\
\hline New Jersey & 1.000 & 0.3273 & 0.9123 & 9.0 & 3.0 & 9.1 & 0.6294 & 0.2054 & 0.5834 \\
\hline New Mexico & 1.000 & 0.2813 & 0.8969 & 19.9 & 3.8 & 13.0 & 0.6192 & 0.1614 & 0.5737 \\
\hline New York & 1.000 & 0.3285 & 0.9041 & 11.7 & 2.6 & 9.2 & 0.6269 & 0.2138 & 0.5838 \\
\hline North Carolina & 1.000 & 0.2707 & 0.9720 & 19.3 & 3.1 & 12.2 & 0.6197 & 0.1592 & 0.5913 \\
\hline North Dakota & 1.000 & 0.2287 & 0.6792 & 29.1 & 3.2 & 10.1 & 0.6106 & 0.1198 & 0.4056 \\
\hline Ohio & 1.000 & 0.2931 & 0.8591 & 16.1 & 3.4 & 10.4 & 0.6227 & 0.1735 & 0.5065 \\
\hline Oklahoma & 1.000 & 0.2881 & 0.9957 & 21.2 & 3.7 & 13.6 & 0.6180 & 0.1646 & 0.5958 \\
\hline Oregon & 1.000 & 0.3222 & 0.9636 & 19.5 & 4.0 & 12.2 & 0.6196 & 0.1951 & 0.5937 \\
\hline Pennsylvania & 1.000 & 0.3379 & 1.1084 & 19.7 & 3.4 & 12.4 & 0.6193 & 0.2049 & 0.6700 \\
\hline Rhode Island & 1.000 & 0.2090 & 0.7460 & 15.0 & 2.4 & 9.2 & 0.6237 & 0.1253 & 0.4821 \\
\hline South Carolina & 1.000 & 0.2369 & 0.8369 & 15.8 & 2.8 & 11.2 & 0.6230 & 0.1385 & 0.5153 \\
\hline South Dakota & 1.000 & 0.2231 & 0.8183 & 19.1 & 2.8 & 11.9 & 0.6199 & 0.1255 & 0.4809 \\
\hline Tennessee & 1.000 & 0.2943 & 1.0322 & 9.5 & 3.3 & 12.4 & 0.6288 & 0.1752 & 0.6108 \\
\hline Texas & 1.000 & 0.3375 & 1.1790 & 18.8 & 3.4 & 12.9 & 0.6202 & 0.2044 & 0.7107 \\
\hline Utah & 1.000 & 0.3061 & 1.2152 & 14.6 & 3.9 & 16.4 & 0.6241 & 0.1809 & 0.7340 \\
\hline Vermont & 1.000 & 0.2612 & 0.8291 & 17.3 & 3.6 & 11.9 & 0.6216 & 0.1507 & 0.5126 \\
\hline Virginia & 1.000 & 0.3002 & 1.0770 & 19.9 & 3.2 & 12.7 & 0.6192 & 0.1812 & 0.6956 \\
\hline Washington & 1.000 & 0.2900 & 0.9189 & 16.0 & 3.2 & 10.4 & 0.6228 & 0.1753 & 0.5678 \\
\hline West Virginia & 1.000 & 0.2068 & 0.6378 & 15.1 & 2.6 & 9.3 & 0.6237 & 0.1131 & 0.3881 \\
\hline Wisconsin & 1.000 & 0.2870 & 0.9176 & 22.0 & 3.4 & 11.5 & 0.6172 & 0.1659 & 0.5394 \\
\hline Wyoming & 1.000 & 0.2365 & 0.6838 & 19.3 & 3.0 & 10.0 & 0.6198 & 0.1359 & 0.4237 \\
\hline
\end{tabular}

Source: Implan 50 state data package, 2001 (MIG, Inc. 2004). 


\section{Appendix B-Economic Impacts by State}

States listed by total output impact in descending order.

Table B-1. Economic impacts of sod production, by state, 2002.

\begin{tabular}{|c|c|c|c|c|c|c|c|c|c|c|}
\hline State & Farms & $\begin{array}{c}\text { Harvest } \\
\text { Value } \\
(\$ 1000)\end{array}$ & $\begin{array}{l}\text { Export } \\
\text { Sales } \\
(\$ 1000)\end{array}$ & $\begin{array}{l}\text { Indirect } \\
\text { Output } \\
\text { Impact } \\
(\mathrm{Mn} \$)\end{array}$ & $\begin{array}{l}\text { Induced } \\
\text { Output } \\
\text { Impact } \\
(\mathrm{Mn} \$)\end{array}$ & $\begin{array}{l}\text { Total } \\
\text { Output } \\
\text { Impact } \\
(\mathrm{Mn} \$)\end{array}$ & $\begin{array}{l}\text { Emplo } \\
\text { yment } \\
\text { Impact } \\
\text { (jobs) }\end{array}$ & $\begin{array}{l}\text { Value } \\
\text { Added } \\
\text { Impact } \\
(\mathrm{Mn} \$)\end{array}$ & $\begin{array}{l}\text { Labor } \\
\text { Income } \\
\text { Impact } \\
(\mathrm{Mn} \$)\end{array}$ & $\begin{array}{c}\text { Indirect } \\
\text { Business } \\
\text { Tax Impact } \\
\text { (Mn\$) }\end{array}$ \\
\hline Florida & 235 & 306,800 & 9,204 & 0.5 & 12.1 & 319.4 & 3,544 & 294.3 & 130.9 & 5.4 \\
\hline Texas & 205 & 146,826 & 14,095 & 5.4 & 15.6 & 167.8 & 1,976 & 99.1 & 54.2 & 2.3 \\
\hline Alabama & 96 & 98,820 & 9,487 & 0.1 & 9.1 & 108.1 & 1,115 & 102.4 & 34.8 & 2.4 \\
\hline Georgia & 92 & 94,408 & 9,063 & 0.1 & 11.3 & 105.8 & 761 & 99.5 & 35.6 & 2.4 \\
\hline Oklahoma & 95 & 68,341 & 6,561 & 2.4 & 6.0 & 76.7 & 993 & 42.7 & 23.7 & 0.9 \\
\hline California & 62 & 60,923 & 5,849 & 1.4 & 7.2 & 69.6 & 553 & 48.7 & 26.7 & 1.0 \\
\hline Minnesota & 89 & 49,742 & 11,291 & 4.3 & 10.6 & 64.6 & 424 & 31.9 & 18.9 & 1.1 \\
\hline South Carolina & 27 & 53,716 & 5,157 & 0.1 & 5.0 & 58.8 & 651 & 55.7 & 14.9 & 1.2 \\
\hline Colorado & 48 & 38,553 & 5,667 & 1.6 & 6.6 & 46.7 & 287 & 28.5 & 16.9 & 0.7 \\
\hline North Carolina & 87 & 41,941 & 4,026 & 0.1 & 4.4 & 46.3 & 265 & 43.7 & 15.0 & 1.0 \\
\hline New Jersey & 53 & 38,679 & 1,857 & 0.2 & 1.6 & 40.5 & 583 & 33.6 & 16.5 & 0.6 \\
\hline Arkansas & 58 & 34,458 & 3,308 & 0.2 & 2.8 & 37.5 & 347 & 32.7 & 14.2 & 0.7 \\
\hline Tennessee & 56 & 32,240 & 3,095 & 1.2 & 2.8 & 36.2 & 926 & 19.3 & 10.6 & 0.4 \\
\hline Illinois & 40 & 27,303 & 6,198 & 1.8 & 6.8 & 35.9 & 237 & 22.2 & 11.8 & 0.7 \\
\hline Michigan & 54 & 31,792 & 1,526 & 0.5 & 1.2 & 33.5 & 317 & 17.2 & 0.2 & 0.2 \\
\hline Ohio & 62 & 29,227 & 1,403 & 0.4 & 1.0 & 30.7 & 318 & 17.8 & 9.2 & 0.3 \\
\hline New York & 14 & 23,457 & 5,325 & 0.8 & 4.4 & 28.7 & 248 & 20.5 & 11.7 & 0.5 \\
\hline Idaho & 38 & 23,349 & 3,432 & 0.0 & 3.6 & 27.0 & 190 & 25.1 & 15.1 & 0.4 \\
\hline Missouri & 53 & 22,985 & 2,207 & 0.7 & 2.0 & 25.8 & 308 & 13.7 & 7.6 & 0.3 \\
\hline Utah & 46 & 20,033 & 2,945 & 0.3 & 3.9 & 24.2 & 245 & 19.8 & 11.4 & 0.4 \\
\hline Virginia & 25 & 22,662 & 1,088 & 0.2 & 1.1 & 24.0 & 363 & 16.4 & 8.7 & 0.3 \\
\hline Indiana & 38 & 17,337 & 3,935 & 1.2 & 3.1 & 21.6 & 169 & 12.3 & 6.6 & 0.4 \\
\hline Kansas & 49 & 19,036 & 1,827 & 0.7 & 1.3 & 21.1 & 107 & 9.2 & 5.4 & 0.2 \\
\hline Iowa & 33 & 16,517 & 3,749 & 1.2 & 2.4 & 20.1 & 117 & 9.8 & 5.1 & 0.3 \\
\hline Wisconsin & 63 & 15,024 & 3,411 & 1.0 & 2.8 & 18.7 & 154 & 10.5 & 6.5 & 0.3 \\
\hline Arizona & 13 & 15,819 & 2,325 & 0.2 & 2.6 & 18.6 & 109 & 15.3 & 8.3 & 0.3 \\
\hline Mississippi & 47 & 16,666 & 1,600 & 0.0 & 1.4 & 18.1 & 222 & 17.2 & 7.1 & 0.4 \\
\hline Maryland & 29 & 15,450 & 742 & 0.0 & 1.0 & 16.5 & 145 & 14.6 & 6.5 & 0.3 \\
\hline Washington & 41 & 14,384 & 1,381 & 0.2 & 1.4 & 16.0 & 174 & 13.2 & 8.2 & 0.2 \\
\hline Kentucky & 54 & 14,536 & 698 & 0.0 & 0.6 & 15.2 & 237 & 13.6 & 6.3 & 0.2 \\
\hline Nebraska & 38 & 10,297 & 2,338 & 0.6 & 1.6 & 12.6 & 61 & 5.9 & 3.4 & 0.2 \\
\hline Louisiana & 23 & 10,520 & 1,010 & 0.2 & 0.9 & 11.6 & 132 & 8.0 & 4.3 & 0.2 \\
\hline Oregon & 14 & 9,987 & 959 & 0.3 & 0.9 & 11.2 & 154 & 7.0 & 4.8 & 0.1 \\
\hline Rhode Island & 15 & 8,378 & 1,902 & 0.4 & 1.3 & 10.1 & 148 & 6.2 & 3.7 & 0.1 \\
\hline Delaware & 6 & 7,141 & 343 & 0.0 & 0.3 & 7.4 & 41 & 7.2 & 2.4 & 0.2 \\
\hline Montana & 16 & 6,115 & 899 & 0.2 & 0.6 & 6.9 & 47 & 3.8 & 2.2 & 0.1 \\
\hline Pennsylvania & 24 & 6,506 & 312 & 0.1 & 0.3 & 6.9 & 74 & 5.1 & 2.9 & 0.1 \\
\hline New Mexico & 5 & 5,887 & 865 & 0.1 & 0.9 & 6.8 & 45 & 5.9 & 3.4 & 0.1 \\
\hline Connecticut & 10 & 4,273 & 970 & 0.0 & 1.0 & 5.3 & 61 & 4.8 & 2.5 & 0.1 \\
\hline Maine & 10 & 3,931 & 892 & 0.1 & 0.8 & 4.8 & 62 & 3.6 & 2.1 & 0.1 \\
\hline Nevada & 11 & 3,574 & 525 & 0.0 & 0.6 & 4.2 & 31 & 3.9 & 2.5 & 0.1 \\
\hline Wyoming & 9 & 3,028 & 445 & 0.1 & 0.3 & 3.4 & 21 & 1.9 & 1.2 & 0.0 \\
\hline Massachusetts & 6 & 1,333 & 303 & 0.1 & 0.3 & 1.7 & 30 & 1.0 & 0.7 & 0.0 \\
\hline South Dakota & 3 & 667 & 151 & 0.0 & 0.1 & 0.8 & 4 & 0.4 & 0.2 & 0.0 \\
\hline New Hampshire & 2 & 444 & 101 & 0.0 & 0.1 & 0.6 & 9 & 0.3 & 0.2 & 0.0 \\
\hline Alaska & 2 & 498 & 48 & 0.0 & 0.0 & 0.5 & 4 & 0.3 & 0.1 & 0.0 \\
\hline Hawaii & 20 & 433 & 42 & 0.0 & 0.1 & 0.5 & 7 & 0.4 & 0.3 & 0.0 \\
\hline West Virginia & 2 & 403 & 19 & 0.0 & 0.0 & 0.4 & 14 & 0.1 & 0.1 & 0.0 \\
\hline North Dakota & 3 & 92 & 21 & 0.0 & 0.0 & 0.1 & 1 & 0.0 & 0.0 & 0.0 \\
\hline Vermont & 3 & 10 & 2 & 0.0 & 0.0 & 0.0 & 0 & 0.0 & 0.0 & 0.0 \\
\hline Total U.S. & 2,124 & $1,494,543$ & 144,598 & 28.9 & 146.2 & $1,669.6$ & 17,028 & $1,266.3$ & 585.8 & 27.2 \\
\hline
\end{tabular}


Table B-2. Economic impacts of lawncare services, by state, 2002.

\begin{tabular}{|c|c|c|c|c|c|c|c|c|c|c|c|}
\hline State & $\begin{array}{c}\text { Establish } \\
\text {-ments }\end{array}$ & $\begin{array}{c}\text { Direct } \\
\text { Employ } \\
\text { ment }\end{array}$ & $\begin{array}{l}\text { Direct } \\
\text { Output } \\
\text { (\$Mn) }\end{array}$ & $\begin{array}{l}\text { Indirect } \\
\text { Output } \\
\text { Impact } \\
(\mathrm{Mn} \$)\end{array}$ & $\begin{array}{c}\text { Induced } \\
\text { Output } \\
\text { Impact } \\
\text { (Mn\$) }\end{array}$ & $\begin{array}{l}\text { Total } \\
\text { Output } \\
\text { Impact } \\
(\mathrm{Mn} \$)\end{array}$ & $\begin{array}{l}\text { Employ } \\
\text { ment } \\
\text { Impact } \\
\text { (jobs) }\end{array}$ & $\begin{array}{l}\text { Value } \\
\text { Added } \\
\text { Impact } \\
(\$ M n)\end{array}$ & $\begin{array}{l}\text { Labor } \\
\text { Income } \\
\text { Impact } \\
\text { (\$Mn) }\end{array}$ & $\begin{array}{c}\text { Indirect } \\
\text { Business } \\
\text { Tax } \\
\text { Impact } \\
(\$ M n)\end{array}$ & $\begin{array}{l}\text { Export } \\
\text { Share }\end{array}$ \\
\hline California & 3,643 & 38,524 & 1,915 & 158 & 817 & 2,889 & 48,547 & 1,972 & 1,580 & 75 & $30.2 \%$ \\
\hline Florida & 3,160 & 20,097 & 901 & 74 & 353 & 1,328 & 25,281 & 895 & 714 & 34 & $30.1 \%$ \\
\hline Texas & 1,812 & 16,387 & 777 & 65 & 269 & 1,111 & 20,113 & 729 & 585 & 28 & $27.0 \%$ \\
\hline Illinois & 1,501 & 7,555 & 657 & 40 & 219 & 916 & 10,303 & 624 & 506 & 22 & $24.3 \%$ \\
\hline Ohio & 1,719 & 10,185 & 574 & 44 & 167 & 785 & 12,821 & 517 & 419 & 17 & $30.5 \%$ \\
\hline New Jersey & 1,787 & 7,203 & 494 & 41 & 158 & 692 & 9,200 & 473 & 383 & 17 & $30.9 \%$ \\
\hline Pennsylvania & 1,748 & 8,449 & 524 & 25 & 118 & 667 & 10,067 & 454 & 373 & 14 & $18.4 \%$ \\
\hline North Carolina & 1,312 & 7,995 & 361 & 50 & 219 & 630 & 11,390 & 410 & 318 & 18 & $55.3 \%$ \\
\hline Virginia & 1,022 & 7,945 & 413 & 35 & 166 & 615 & 10,370 & 409 & 328 & 15 & $34.3 \%$ \\
\hline Maryland & 801 & 6,212 & 368 & 36 & 197 & 601 & 8,924 & 407 & 324 & 16 & $39.4 \%$ \\
\hline New York & 2,408 & 7,089 & 547 & 8 & 36 & 592 & 7,540 & 426 & 361 & 10 & $6.7 \%$ \\
\hline Georgia & 1,136 & 8,416 & 419 & 27 & 135 & 581 & 10,290 & 394 & 318 & 14 & $25.1 \%$ \\
\hline Michigan & 1,469 & 5,588 & 438 & 20 & 87 & 545 & 6,820 & 370 & 11 & 11 & $18.7 \%$ \\
\hline Massachusetts & 1,237 & 4,240 & 374 & 30 & 140 & 544 & 6,038 & 371 & 300 & 14 & $32.0 \%$ \\
\hline Colorado & 763 & 5,148 & 317 & 28 & 147 & 492 & 7,133 & 328 & 262 & 13 & $34.2 \%$ \\
\hline Arizona & 688 & 6,890 & 300 & 32 & 155 & 487 & 9,164 & 325 & 256 & 14 & $45.4 \%$ \\
\hline Indiana & 798 & 4,453 & 268 & 21 & 93 & 383 & 5,907 & 249 & 200 & 9 & $34.7 \%$ \\
\hline Washington & 978 & 4,604 & 265 & 23 & 95 & 383 & 5,954 & 256 & 207 & 9 & $33.9 \%$ \\
\hline Connecticut & 897 & 3,075 & 250 & 25 & 103 & 377 & 4,399 & 259 & 207 & 10 & $39.7 \%$ \\
\hline Wisconsin & 739 & 3,043 & 228 & 19 & 87 & 334 & 4,418 & 221 & 177 & 8 & $37.2 \%$ \\
\hline South Carolina & 654 & 3,966 & 174 & 30 & 122 & 326 & 6,017 & 212 & 147 & 10 & $74.7 \%$ \\
\hline Tennessee & 598 & 3,972 & 207 & 20 & 90 & 318 & 5,353 & 211 & 167 & 8 & $37.9 \%$ \\
\hline Nevada & 289 & 3,440 & 180 & 21 & 112 & 313 & 4,959 & 213 & 167 & 9 & $62.0 \%$ \\
\hline Minnesota & 752 & 2,622 & 197 & 19 & 91 & 306 & 3,910 & 201 & 160 & 8 & $36.0 \%$ \\
\hline Missouri & 736 & 3,982 & 216 & 4 & 16 & 236 & 4,238 & 157 & 133 & 4 & $6.4 \%$ \\
\hline Alabama & 417 & 3,117 & 140 & 16 & 62 & 219 & 4,177 & 141 & 111 & 6 & $47.2 \%$ \\
\hline Oregon & 541 & 2,818 & 153 & 12 & 45 & 210 & 3,556 & 142 & 115 & 5 & $26.8 \%$ \\
\hline Kansas & 310 & 1,720 & 93 & 7 & 32 & 132 & 2,234 & 86 & 69 & 3 & $33.0 \%$ \\
\hline Kentucky & 378 & 1,826 & 91 & 7 & 26 & 123 & 2,271 & 80 & 65 & 3 & $33.9 \%$ \\
\hline Iowa & 330 & 1,397 & 81 & 5 & 21 & 107 & 1,754 & 70 & 57 & 2 & $28.2 \%$ \\
\hline Oklahoma & 276 & 2,883 & 96 & 2 & 9 & 107 & 3,037 & 70 & 59 & 2 & $8.3 \%$ \\
\hline Utah & 341 & 1,221 & 67 & 7 & 32 & 106 & 1,744 & 68 & 54 & 3 & $35.9 \%$ \\
\hline New Hampshire & 278 & 940 & 66 & 7 & 30 & 104 & 1,401 & 68 & 54 & 3 & $43.4 \%$ \\
\hline Hawaii & 126 & 1,120 & 55 & 7 & 34 & 96 & 1,653 & 65 & 51 & 3 & $51.5 \%$ \\
\hline Louisiana & 331 & 1,798 & 76 & 2 & 7 & 85 & 1,931 & 55 & 46 & 1 & $10.3 \%$ \\
\hline Arkansas & 218 & 1,300 & 58 & 5 & 21 & 84 & 1,671 & 54 & 43 & 2 & $42.2 \%$ \\
\hline Idaho & 227 & 983 & 55 & 6 & 22 & 83 & 1,401 & 54 & 43 & 2 & $42.4 \%$ \\
\hline Maine & 227 & 751 & 48 & 6 & 26 & 79 & 1,210 & 51 & 41 & 2 & $57.9 \%$ \\
\hline Rhode Island & 251 & 528 & 45 & 6 & 28 & 79 & 954 & 53 & 41 & 2 & $73.2 \%$ \\
\hline Delaware & 130 & 864 & 44 & 6 & 25 & 74 & 1,238 & 48 & 38 & 2 & $68.6 \%$ \\
\hline Nebraska & 271 & 920 & 55 & 3 & 11 & 69 & 1,116 & 45 & 37 & 1 & $20.2 \%$ \\
\hline New Mexico & 118 & 1,073 & 47 & 3 & 14 & 64 & 1,322 & 42 & 34 & 1 & $30.0 \%$ \\
\hline Mississippi & 215 & 985 & 40 & 4 & 15 & 59 & 1,259 & 37 & 30 & 1 & $44.8 \%$ \\
\hline West Virginia & 115 & 812 & 40 & 2 & 7 & 49 & 960 & 32 & 27 & 1 & $26.0 \%$ \\
\hline Vermont & 141 & 324 & 26 & 3 & 10 & 39 & 511 & 25 & 20 & 1 & $44.8 \%$ \\
\hline Montana & 127 & 286 & 17 & 1 & 4 & 22 & 366 & 14 & 11 & 0 & $30.6 \%$ \\
\hline Wyoming & 82 & 195 & 16 & 1 & 4 & 22 & 280 & 14 & 11 & 1 & $38.8 \%$ \\
\hline Alaska & 46 & 156 & 15 & 0 & 1 & 16 & 173 & 11 & 9 & 0 & $9.6 \%$ \\
\hline South Dakota & 87 & 241 & 12 & 1 & 2 & 14 & 278 & 9 & 7 & 0 & $19.0 \%$ \\
\hline North Dakota & 75 & 154 & 9 & 0 & 2 & 11 & 188 & 7 & 6 & 0 & $26.5 \%$ \\
\hline Total & 38,306 & 229,490 & 12,811 & 1,013 & 4,682 & 18,507 & 295,841 & 12,425 & 9,685 & 458 & \\
\hline
\end{tabular}


Table B-3. Economic impacts of lawncare goods retailing, by state, 2002.

\begin{tabular}{|c|c|c|c|c|c|c|c|c|c|c|}
\hline State & $\begin{array}{c}\text { Reported } \\
\text { Employment } \\
\text { for Lawn \& } \\
\text { Garden Stores } \\
(2002) \\
\end{array}$ & $\begin{array}{c}\text { Estimated } \\
\text { Lawncare } \\
\text { Sales Gross } \\
\text { Margin } \\
(\mathrm{Mn} \$) \\
\end{array}$ & $\begin{array}{c}\text { Direct } \\
\text { Output } \\
\text { Impacts } \\
(\mathrm{Mn} \$)\end{array}$ & $\begin{array}{c}\text { Indirect } \\
\text { Output } \\
\text { Impacts } \\
(\mathrm{Mn} \$)\end{array}$ & $\begin{array}{c}\text { Induced } \\
\text { Output } \\
\text { Impacts } \\
(\mathrm{Mn} \$)\end{array}$ & $\begin{array}{c}\text { Total } \\
\text { Output } \\
\text { Impacts } \\
(\mathrm{Mn} \$)\end{array}$ & $\begin{array}{l}\text { Employ } \\
\text { ment } \\
\text { Impacts } \\
\text { (jobs) }\end{array}$ & $\begin{array}{c}\text { Value } \\
\text { Added } \\
\text { Impacts } \\
(\$ M n)\end{array}$ & $\begin{array}{l}\text { Labor } \\
\text { Income } \\
\text { Impacts } \\
(\$ M n)\end{array}$ & $\begin{array}{c}\text { Indirect } \\
\text { Business } \\
\text { Tax } \\
\text { Impacts } \\
(\$ \mathrm{Mn}) \\
\end{array}$ \\
\hline California & 14,935 & 294.3 & 294.3 & 87.6 & 416.0 & 797.9 & 9,370 & 525.2 & 358.3 & 60.5 \\
\hline Texas & 12,839 & 253.0 & 253.0 & 69.6 & 322.8 & 645.4 & 8,270 & 412.7 & 276.2 & 51.3 \\
\hline Illinois & 7,865 & 155.0 & 155.0 & 47.5 & 214.9 & 417.4 & 5,218 & 267.8 & 181.4 & 31.5 \\
\hline Florida & 5,986 & 117.9 & 117.9 & 34.1 & 154.6 & 306.6 & 4,114 & 200.0 & 134.4 & 23.9 \\
\hline New York & 6,708 & 132.2 & 132.2 & 37.4 & 131.3 & 300.9 & 3,666 & 201.6 & 136.4 & 24.9 \\
\hline Missouri & 5,882 & 115.9 & 115.9 & 33.3 & 141.1 & 290.3 & 4,055 & 185.4 & 124.5 & 22.7 \\
\hline Virginia & 5,651 & 111.3 & 111.3 & 29.9 & 135.1 & 276.3 & 3,781 & 182.3 & 124.8 & 21.2 \\
\hline Wisconsin & 6,068 & 119.6 & 119.6 & 29.4 & 123.5 & 272.4 & 3,861 & 173.5 & 117.6 & 21.8 \\
\hline Indiana & 5,571 & 109.8 & 109.8 & 26.8 & 113.1 & 249.7 & 3,568 & 157.4 & 105.3 & 20.2 \\
\hline North Carolina & 5,397 & 106.3 & 106.3 & 24.4 & 115.7 & 246.5 & 3,487 & 159.1 & 107.4 & 19.9 \\
\hline Tennessee & 4,797 & 94.5 & 94.5 & 23.8 & 107.0 & 225.3 & 3,071 & 143.8 & 95.7 & 17.9 \\
\hline Washington & 4,798 & 94.5 & 94.5 & 22.9 & 95.6 & 213.1 & 2,742 & 139.5 & 94.7 & 17.4 \\
\hline Iowa & 4,423 & 87.2 & 87.2 & 18.3 & 79.4 & 184.9 & 2,797 & 117.4 & 78.8 & 15.4 \\
\hline Colorado & 3,211 & 63.3 & 63.3 & 18.2 & 89.6 & 171.0 & 2,132 & 111.7 & 76.1 & 13.1 \\
\hline Maryland & 3,126 & 61.6 & 61.6 & 15.7 & 84.3 & 161.6 & 2,082 & 109.2 & 75.6 & 12.1 \\
\hline Kentucky & 3,916 & 77.2 & 77.2 & 16.0 & 64.1 & 157.2 & 2,348 & 100.2 & 67.4 & 13.3 \\
\hline Oregon & 3,260 & 64.2 & 64.2 & 18.0 & 68.1 & 150.3 & 2,113 & 97.8 & 65.9 & 12.1 \\
\hline New Jersey & 3,158 & 62.2 & 62.2 & 17.3 & 64.7 & 144.2 & 1,653 & 96.7 & 65.9 & 11.8 \\
\hline South Carolina & 2,302 & 45.4 & 45.4 & 9.0 & 42.4 & 96.8 & 1,427 & 63.0 & 40.9 & 8.1 \\
\hline Idaho & 2,190 & 43.2 & 43.2 & 9.7 & 41.0 & 93.9 & 1,390 & 61.2 & 41.5 & 7.8 \\
\hline Arkansas & 2,236 & 44.1 & 44.1 & 9.6 & 37.2 & 90.9 & 1,488 & 57.1 & 38.3 & 7.6 \\
\hline Mississippi & 2,251 & 44.4 & 44.4 & 8.8 & 37.5 & 90.6 & 1,472 & 57.5 & 38.9 & 7.5 \\
\hline Alabama & 2,078 & 40.9 & 40.9 & 8.8 & 38.6 & 88.3 & 1,329 & 56.8 & 38.2 & 7.2 \\
\hline Utah & 1,419 & 28.0 & 28.0 & 7.8 & 37.6 & 73.3 & 1,072 & 46.9 & 32.0 & 5.5 \\
\hline South Dakota & 1,502 & 29.6 & 29.6 & 5.6 & 27.3 & 62.4 & 1,029 & 39.4 & 26.7 & 5.1 \\
\hline Montana & 1,338 & 26.4 & 26.4 & 4.6 & 22.2 & 53.1 & 887 & 33.9 & 23.0 & 4.4 \\
\hline New Hampshire & 899 & 17.7 & 17.7 & 4.1 & 19.0 & 40.8 & 523 & 26.5 & 18.1 & 3.3 \\
\hline Nevada & 926 & 18.2 & 18.2 & 4.0 & 18.1 & 40.4 & 503 & 26.9 & 18.4 & 3.4 \\
\hline New Mexico & 907 & 17.9 & 17.9 & 4.3 & 17.9 & 40.0 & 631 & 26.2 & 17.9 & 3.2 \\
\hline North Dakota & 975 & 19.2 & 19.2 & 3.7 & 14.7 & 37.6 & 631 & 23.8 & 16.3 & 3.1 \\
\hline Maine & 802 & 15.8 & 15.8 & 3.0 & 14.8 & 33.5 & 524 & 21.8 & 15.0 & 2.8 \\
\hline West Virginia & 829 & 16.3 & 16.3 & 2.9 & 11.3 & 30.5 & 505 & 19.5 & 13.2 & 2.7 \\
\hline Vermont & 616 & 12.1 & 12.1 & 2.7 & 11.4 & 26.2 & 398 & 17.2 & 11.7 & 2.1 \\
\hline Delaware & 500 & 9.9 & 9.9 & 1.9 & 8.3 & 20.1 & 271 & 13.1 & 8.9 & 1.7 \\
\hline Hawaii & 326 & 6.4 & 6.4 & 1.5 & 7.6 & 15.5 & 216 & 10.6 & 7.3 & 1.2 \\
\hline Wyoming & 375 & 7.4 & 7.4 & 1.4 & 5.5 & 14.3 & 233 & 9.3 & 6.2 & 1.3 \\
\hline Alaska & 175 & 3.4 & 3.4 & 0.7 & 2.8 & 7.0 & 96 & 4.7 & 3.3 & 0.6 \\
\hline Rhode Island & 150 & 3.0 & 3.0 & 0.5 & 2.5 & 5.9 & 80 & 4.0 & 2.7 & 0.5 \\
\hline
\end{tabular}


Table B-4. Economic impacts of lawn equipment manufacturing, by state, 2002.

\begin{tabular}{|c|c|c|c|c|c|c|c|c|c|c|c|}
\hline State & $\begin{array}{c}\text { Lawn \& } \\
\text { Garden } \\
\text { Equip. } \\
\text { Manuf } \\
\text { Establish } \\
\text {-ments }\end{array}$ & $\begin{array}{c}\text { Direct } \\
\text { Employme } \\
\text { nt in Lawn } \\
\text { \& Garden } \\
\text { Equip. } \\
\text { Manuf. } \\
\text { (jobs) }\end{array}$ & $\begin{array}{c}\text { Lawncare } \\
\text { Eqmt. } \\
\text { Direct } \\
\text { Output } \\
\text { (\$Mn)* }\end{array}$ & $\begin{array}{l}\text { Indirect } \\
\text { Output } \\
\text { Impacts } \\
(\mathrm{Mn} \$)\end{array}$ & $\begin{array}{c}\text { Induced } \\
\text { Output } \\
\text { Impacts } \\
(\mathrm{Mn} \$)\end{array}$ & $\begin{array}{c}\text { Total } \\
\text { Output } \\
\text { Impacts } \\
(\mathrm{Mn} \$)\end{array}$ & $\begin{array}{l}\text { Employ } \\
\text { ment } \\
\text { Impacts } \\
\text { (jobs) }\end{array}$ & $\begin{array}{l}\text { Value } \\
\text { Added } \\
\text { Impacts } \\
(\$ M n)^{*}\end{array}$ & $\begin{array}{l}\text { Labor } \\
\text { Income } \\
\text { Impacts } \\
\text { (\$Mn)* }\end{array}$ & $\begin{array}{c}\text { Indirect } \\
\text { Business } \\
\text { Tax } \\
\text { Impacts } \\
(\$ M n)^{*}\end{array}$ & $\begin{array}{c}\text { Export } \\
\text { Share }\end{array}$ \\
\hline Wisconsin & 8 & 3,750 & 874.3 & 119.5 & 161.5 & $1,155.4$ & 5,383 & 443.9 & 234.2 & 22.1 & $29.7 \%$ \\
\hline Tennessee & 8 & 3,602 & 839.8 & 113.5 & 140.5 & 1,093.9 & 5,313 & 354.0 & 187.8 & 19.6 & $27.8 \%$ \\
\hline South Carolina & 3 & 3,750 & 874.3 & 101.5 & 108.6 & $1,084.5$ & 5,211 & 318.8 & 193.1 & 16.2 & $27.6 \%$ \\
\hline Georgia & 7 & 1,750 & 408.0 & 44.0 & 60.0 & 512.1 & 2,409 & 155.1 & 82.8 & 8.7 & $22.1 \%$ \\
\hline Arkansas & 3 & 1,750 & 408.0 & 47.7 & 42.2 & 497.9 & 2,511 & 122.6 & 65.0 & 6.8 & $28.7 \%$ \\
\hline Ohio & 9 & 1,750 & 408.0 & 37.4 & 43.6 & 489.1 & 2,117 & 152.1 & 78.5 & 6.1 & $23.0 \%$ \\
\hline Illinois & 7 & 1,750 & 408.0 & 23.2 & 32.4 & 463.6 & 1,819 & 140.4 & 70.4 & 6.3 & $9.5 \%$ \\
\hline Indiana & 12 & 924 & 215.4 & 20.7 & 21.5 & 257.6 & 1,133 & 74.9 & 38.5 & 3.6 & $17.9 \%$ \\
\hline Minnesota & 6 & 750 & 174.9 & 17.3 & 29.7 & 221.8 & 1,037 & 75.1 & 40.0 & 4.1 & $24.6 \%$ \\
\hline Mississippi & 3 & 750 & 174.9 & 20.0 & 18.5 & 213.4 & 1,023 & 59.6 & 31.0 & 3.0 & $26.8 \%$ \\
\hline Arizona & 3 & 750 & 174.9 & 11.4 & 18.1 & 204.4 & 892 & 62.3 & 31.9 & 3.0 & $18.1 \%$ \\
\hline Missouri & 4 & 750 & 174.9 & 9.0 & 10.6 & 194.5 & 815 & 49.6 & 25.0 & 2.2 & $9.5 \%$ \\
\hline New York & 3 & 750 & 174.9 & 8.5 & 9.0 & 192.3 & 722 & 55.7 & 27.5 & 2.4 & $9.5 \%$ \\
\hline Virginia & 1 & 750 & 174.9 & 5.9 & 9.5 & 190.3 & 741 & 53.6 & 26.0 & 2.2 & $9.5 \%$ \\
\hline California & 8 & 702 & 163.7 & 6.6 & 11.7 & 182.0 & 693 & 56.2 & 28.0 & 2.5 & $9.5 \%$ \\
\hline Michigan & 6 & 634 & 147.8 & 5.5 & 9.3 & 162.7 & 522 & 65.2 & 2.5 & 2.5 & $9.5 \%$ \\
\hline Kansas & 5 & 375 & 87.4 & 7.3 & 10.6 & 105.3 & 475 & 34.4 & 16.7 & 1.8 & $23.4 \%$ \\
\hline North Carolina & 3 & 375 & 87.4 & 3.5 & 5.1 & 96.0 & 355 & 31.6 & 15.4 & 1.3 & $9.5 \%$ \\
\hline Pennsylvania & 10 & 175 & 40.8 & 1.8 & 2.7 & 45.3 & 166 & 15.3 & 7.4 & 0.6 & $9.5 \%$ \\
\hline Iowa & 1 & 60 & 14.0 & 3.5 & 3.6 & 21.2 & 124 & 7.1 & 3.9 & 0.5 & $56.8 \%$ \\
\hline Nebraska & 2 & 60 & 14.0 & 1.5 & 2.3 & 17.7 & 87 & 6.2 & 3.2 & 0.3 & $29.6 \%$ \\
\hline Florida & 5 & 62 & 14.5 & 0.5 & 0.8 & 15.8 & 67 & 3.7 & 1.9 & 0.2 & $9.5 \%$ \\
\hline Oklahoma & 1 & 60 & 14.0 & 0.6 & 0.7 & 15.3 & 61 & 4.4 & 2.1 & 0.2 & $9.5 \%$ \\
\hline Alabama & 3 & 60 & 14.0 & 0.6 & 0.7 & 15.2 & 59 & 4.3 & 2.1 & 0.2 & $9.5 \%$ \\
\hline New Jersey & 3 & 60 & 14.0 & 0.5 & 0.7 & 15.2 & 54 & 4.8 & 2.4 & 0.2 & $9.5 \%$ \\
\hline Oregon & 1 & 60 & 14.0 & 0.5 & 0.7 & 15.2 & 62 & 4.0 & 2.0 & 0.2 & $9.5 \%$ \\
\hline Texas & 5 & 35 & 8.2 & 0.4 & 0.5 & 9.0 & 38 & 2.2 & 1.1 & 0.1 & $9.5 \%$ \\
\hline Washington & 4 & 19 & 4.4 & 0.1 & 0.2 & 4.8 & 17 & 1.5 & 0.6 & 0.1 & $9.5 \%$ \\
\hline South Dakota & 2 & 10 & 2.3 & 0.1 & 0.2 & 2.7 & 11 & 0.9 & 0.5 & 0.0 & $19.0 \%$ \\
\hline Colorado & 1 & 10 & 2.3 & 0.1 & 0.2 & 2.6 & 11 & 0.7 & 0.3 & 0.0 & $9.5 \%$ \\
\hline Maryland & 1 & 10 & 2.3 & 0.1 & 0.2 & 2.6 & 10 & 0.8 & 0.4 & 0.0 & $9.5 \%$ \\
\hline Utah & 2 & 10 & 2.3 & 0.1 & 0.2 & 2.6 & 11 & 0.8 & 0.4 & 0.0 & $9.5 \%$ \\
\hline Louisiana & 1 & 10 & 2.3 & 0.1 & 0.1 & 2.5 & 10 & 0.7 & 0.3 & 0.0 & $9.5 \%$ \\
\hline Maine & 2 & 10 & 2.3 & 0.1 & 0.1 & 2.5 & 10 & 0.7 & 0.3 & 0.0 & $9.5 \%$ \\
\hline North Dakota & 1 & 10 & 2.3 & 0.1 & 0.1 & 2.5 & 9 & 0.7 & 0.3 & 0.0 & $9.5 \%$ \\
\hline Vermont & 1 & 10 & 2.3 & 0.1 & 0.1 & 2.5 & 10 & 0.8 & 0.4 & 0.0 & $11.3 \%$ \\
\hline Kentucky & 3 & 7 & 1.6 & 0.1 & 0.1 & 1.8 & 7 & 0.5 & 0.2 & 0.0 & $9.5 \%$ \\
\hline Total & 150 & 26,370 & 6,148 & 613.4 & 756.6 & 7,513.7 & 33,995 & $2,364.7$ & $1,224.3$ & 117.3 & \\
\hline
\end{tabular}


Table B-5. Economic impacts of golf courses, by state, 2002. States listed by total output impact in descending order.

\begin{tabular}{|c|c|c|c|c|c|c|c|c|c|c|c|c|}
\hline State & $\begin{array}{c}\text { Establi } \\
\text { shmen } \\
\text { ts }\end{array}$ & $\begin{array}{c}\text { Direct } \\
\text { Employ } \\
\text { ment } \\
\text { (jobs) }\end{array}$ & $\begin{array}{l}\text { Annual } \\
\text { Wages } \\
(\$ M n)\end{array}$ & $\begin{array}{l}\text { Output } \\
\text { (\$Mn) }\end{array}$ & $\begin{array}{c}\text { Indirect } \\
\text { Output } \\
\text { Impacts } \\
(\mathrm{Mn} \$)\end{array}$ & $\begin{array}{c}\text { Induced } \\
\text { Output } \\
\text { Impacts } \\
(\mathrm{Mn} \$)\end{array}$ & $\begin{array}{c}\text { Total } \\
\text { Output } \\
\text { Impacts } \\
(\mathrm{Mn} \$)\end{array}$ & $\begin{array}{l}\text { Employ } \\
\text { ment } \\
\text { Impacts } \\
\text { (jobs) }\end{array}$ & $\begin{array}{c}\text { Value } \\
\text { Added } \\
\text { Impacts } \\
(\$ M n)\end{array}$ & $\begin{array}{l}\text { Labor } \\
\text { Income } \\
\text { Impacts } \\
(\$ M n)\end{array}$ & $\begin{array}{c}\text { Indirect } \\
\text { Business } \\
\text { Tax } \\
\text { Impacts } \\
(\$ M n) \\
\end{array}$ & $\begin{array}{c}\text { Export } \\
\text { Share }\end{array}$ \\
\hline Florida & 587 & 32,861 & 589.5 & $1,554.9$ & 325.1 & 1,208.3 & $3,088.2$ & 50,938 & $1,926.5$ & 1,207.6 & 158.4 & $64.8 \%$ \\
\hline California & 689 & 37,077 & 749.9 & $1,978.0$ & 102.3 & 378.2 & $2,458.5$ & 41,858 & $1,539.9$ & 941.7 & 129.6 & $14.9 \%$ \\
\hline New York & 674 & 11,789 & 395.0 & $1,041.8$ & 0.0 & 0.0 & $1,041.8$ & 11,789 & 653.1 & 388.3 & 56.9 & $0.0 \%$ \\
\hline Texas & 581 & 22,388 & 389.5 & $1,027.4$ & 0.0 & 0.0 & $1,027.4$ & 22,388 & 637.2 & 380.1 & 55.2 & $0.0 \%$ \\
\hline Illinois & 497 & 12,065 & 299.6 & 790.3 & 41.8 & 151.4 & 983.6 & 14,049 & 612.7 & 373.6 & 51.9 & $15.2 \%$ \\
\hline Michigan & 652 & 7,963 & 260.2 & 686.4 & 63.3 & 207.4 & 957.1 & 10,925 & 588.6 & 49.0 & 49.0 & $31.4 \%$ \\
\hline Pennsylvania & 612 & 15,960 & 335.9 & 886.1 & 0.0 & 0.0 & 886.1 & 15,960 & 548.8 & 327.9 & 47.4 & $0.0 \%$ \\
\hline Ohio & 646 & 13,383 & 293.6 & 774.5 & 0.0 & 0.0 & 774.5 & 13,383 & 482.3 & 287.0 & 41.9 & $0.0 \%$ \\
\hline North Carolina & 456 & 13,362 & 243.5 & 642.2 & 0.0 & 0.0 & 642.2 & 13,362 & 398.0 & 238.0 & 34.4 & $0.0 \%$ \\
\hline South Carolina & 284 & 9,349 & 143.5 & 378.6 & 41.1 & 145.3 & 565.0 & 11,777 & 349.4 & 209.3 & 29.2 & $45.9 \%$ \\
\hline New Jersey & 235 & 7,231 & 210.4 & 554.8 & 0.0 & 0.0 & 554.8 & 7,231 & 349.2 & 207.1 & 30.5 & $0.0 \%$ \\
\hline Massachusetts & 326 & 6,576 & 207.7 & 547.8 & 0.0 & 0.0 & 547.8 & 6,576 & 342.0 & 204.2 & 29.6 & $0.0 \%$ \\
\hline Arizona & 196 & 9,618 & 158.7 & 418.5 & 27.7 & 98.6 & 544.7 & 11,120 & 339.3 & 207.3 & 28.5 & $22.5 \%$ \\
\hline Georgia & 279 & 10,534 & 198.8 & 524.4 & 0.0 & 0.0 & 524.4 & 10,534 & 325.2 & 194.5 & 28.1 & $0.0 \%$ \\
\hline Indiana & 334 & 5,324 & 109.2 & 288.0 & 50.4 & 175.4 & 513.7 & 8,053 & 311.8 & 192.2 & 26.4 & $66.4 \%$ \\
\hline Missouri & 262 & 5,339 & 107.1 & 282.5 & 45.2 & 155.6 & 483.4 & 7,799 & 296.8 & 184.1 & 24.7 & $50.2 \%$ \\
\hline Colorado & 125 & 2,987 & 82.4 & 217.4 & 43.8 & 168.1 & 429.2 & 5,320 & 267.3 & 169.3 & 21.8 & $59.9 \%$ \\
\hline Virginia & 245 & 8,440 & 156.8 & 413.6 & 0.0 & 0.0 & 413.6 & 8,440 & 256.1 & 152.8 & 22.2 & $0.0 \%$ \\
\hline Nevada & 62 & 3,348 & 70.1 & 184.8 & 39.7 & 144.3 & 368.9 & 5,379 & 231.9 & 146.9 & 18.8 & $84.5 \%$ \\
\hline Maryland & 142 & 5,896 & 138.1 & 364.2 & 0.0 & 0.0 & 364.2 & 5,896 & 225.9 & 135.2 & 19.5 & $0.0 \%$ \\
\hline Wisconsin & 393 & 5,915 & 134.7 & 355.4 & 0.0 & 0.0 & 355.4 & 5,915 & 219.3 & 131.1 & 18.9 & $0.0 \%$ \\
\hline Connecticut & 157 & 4,257 & 131.0 & 345.5 & 0.0 & 0.0 & 345.5 & 4,257 & 216.6 & 129.2 & 18.8 & $0.0 \%$ \\
\hline Minnesota & 357 & 3,868 & 119.9 & 316.1 & 0.0 & 0.0 & 316.1 & 3,868 & 195.7 & 116.7 & 17.0 & $0.0 \%$ \\
\hline Tennessee & 216 & 5,113 & 97.0 & 255.9 & 12.9 & 45.2 & 313.9 & 5,801 & 195.3 & 117.2 & 16.8 & $17.1 \%$ \\
\hline Washington & 211 & 5,096 & 106.6 & 281.2 & 6.1 & 19.4 & 306.7 & 5,383 & 190.8 & 115.1 & 16.3 & $7.5 \%$ \\
\hline Iowa & 318 & 3,075 & 58.5 & 154.4 & 25.7 & 85.6 & 265.7 & 4,551 & 161.8 & 99.5 & 13.6 & $67.4 \%$ \\
\hline Louisiana & 126 & 3,293 & 54.1 & 142.8 & 27.1 & 93.8 & 263.7 & 4,927 & 162.4 & 101.7 & 13.3 & $73.4 \%$ \\
\hline Alabama & 177 & 4,696 & 79.2 & 208.8 & 11.9 & 38.8 & 259.4 & 5,354 & 159.0 & 96.9 & 13.4 & $22.0 \%$ \\
\hline Hawaii & 50 & 2,579 & 52.9 & 139.6 & 20.1 & 78.2 & 237.9 & 3,848 & 152.5 & 97.4 & 11.8 & $52.5 \%$ \\
\hline Oregon & 148 & 3,610 & 75.9 & 200.3 & 0.0 & 0.0 & 200.3 & 3,610 & 124.1 & 74.0 & 10.7 & $0.0 \%$ \\
\hline Kentucky & 198 & 3,528 & 64.3 & 169.6 & 0.0 & 0.0 & 169.6 & 3,528 & 105.1 & 62.7 & 9.1 & $0.0 \%$ \\
\hline Mississippi & 129 & 2,376 & 36.9 & 97.3 & 15.8 & 54.0 & 167.1 & 3,355 & 101.9 & 63.4 & 8.4 & $73.5 \%$ \\
\hline Kansas & 170 & 3,399 & 61.7 & 162.9 & 0.0 & 0.0 & 162.9 & 3,399 & 100.8 & 60.2 & 8.7 & $0.0 \%$ \\
\hline Oklahoma & 119 & 3,159 & 49.9 & 131.7 & 0.0 & 0.0 & 131.7 & 3,159 & 81.4 & 48.6 & 7.0 & $0.0 \%$ \\
\hline Rhode Island & 61 & 1,151 & 33.2 & 87.6 & 7.3 & 26.0 & 120.9 & 1,555 & 75.8 & 46.5 & 6.3 & $39.8 \%$ \\
\hline Arkansas & 156 & 2,642 & 43.3 & 114.3 & 0.0 & 0.0 & 114.3 & 2,642 & 70.4 & 42.0 & 6.1 & $0.0 \%$ \\
\hline New Hampshire & 84 & 901 & 34.8 & 91.7 & 4.9 & 16.9 & 113.6 & 1,156 & 70.0 & 42.8 & 5.9 & $19.4 \%$ \\
\hline Utah & 55 & 1,193 & 26.5 & 69.8 & 8.5 & 33.9 & 112.3 & 1,758 & 69.1 & 43.1 & 5.7 & $40.0 \%$ \\
\hline Nebraska & 155 & 2,058 & 39.1 & 103.2 & 0.0 & 0.0 & 103.2 & 2,058 & 64.1 & 38.1 & 5.6 & $0.0 \%$ \\
\hline Delaware & 36 & 1,308 & 29.6 & 78.0 & 0.0 & 0.0 & 78.0 & 1,308 & 48.5 & 29.0 & 4.2 & $0.0 \%$ \\
\hline Maine & 105 & 637 & 20.4 & 53.7 & 4.1 & 14.9 & 72.7 & 909 & 44.8 & 27.7 & 3.7 & $33.2 \%$ \\
\hline Montana & 76 & 615 & 16.7 & 44.0 & 6.0 & 21.1 & 71.0 & 1,025 & 43.2 & 26.9 & 3.5 & $61.8 \%$ \\
\hline Idaho & 73 & 1,109 & 23.0 & 60.6 & 2.5 & 7.6 & 70.7 & 1,255 & 43.5 & 27.4 & 3.5 & $14.8 \%$ \\
\hline West Virginia & 91 & 1,078 & 18.8 & 49.7 & 2.9 & 8.9 & 61.5 & 1,243 & 38.0 & 23.0 & 3.3 & $28.1 \%$ \\
\hline South Dakota & 71 & 535 & 12.6 & 33.3 & 4.1 & 15.0 & 52.3 & 804 & 31.7 & 19.6 & 2.7 & $54.9 \%$ \\
\hline New Mexico & 43 & 1,171 & 18.8 & 49.6 & 0.0 & 0.0 & 49.6 & 1,171 & 30.7 & 18.3 & 2.7 & $0.0 \%$ \\
\hline Vermont & 48 & 263 & 13.3 & 35.1 & 0.0 & 0.0 & 35.1 & 263 & 21.8 & 13.0 & 1.9 & $0.0 \%$ \\
\hline Wyoming & 41 & 402 & 8.5 & 22.6 & 1.4 & 4.0 & 27.9 & 479 & 17.3 & 10.4 & 1.5 & $26.0 \%$ \\
\hline North Dakota & 70 & 255 & 7.3 & 19.2 & 0.0 & 0.0 & 19.2 & 255 & 11.7 & 7.0 & 1.0 & $0.0 \%$ \\
\hline Alaska & 18 & 64 & 1.4 & 3.6 & 0.2 & 0.8 & 4.6 & 77 & 2.9 & 1.9 & 0.2 & $28.1 \%$ \\
\hline Total & 11,836 & 310,833 & $6,609.5$ & $17,433.8$ & 941.8 & 3,396.7 & $21,772.3$ & 361,690 & $13,532.2$ & 7,926.7 & $1,145.6$ & \\
\hline
\end{tabular}

